UNIVERSIDADE DE SÃO PAULO - USP

ESCOLA POLITÉCNICA

DEPARTAMENTO DE ENGENHARIA NAVAL E OCEÂNICA

NÍVEL MESTRADO

Fernanda Alves

CARACTERIZAÇÃO DA OFERTA DE CONTÊINERES NO TRANSPORTE MARÍTIMO BRASILEIRO DE LONGO CURSO 
FERNANDA ALVES

\title{
CARACTERIZAÇÃO DA OFERTA DE CONTÊINERES NO TRANSPORTE MARÍTIMO BRASILEIRO DE LONGO CURSO
}

Versão Corrigida

\begin{abstract}
Dissertação apresentada à Escola Politécnica da Universidade de São Paulo, como requisito para obtenção do título de Mestre em Ciências.

Área de Concentração Engenharia Naval e Oceânica.

Orientador: Prof. Dr. Rui Carlos Botter
\end{abstract}

São Paulo

2020 


\section{CARACTERIZAÇÃO DA OFERTA DE CONTÊINERES NO TRANSPORTE MARÍTIMO BRASILEIRO DE LONGO CURSO}

Dissertação apresentada à Escola Politécnica da Universidade de São Paulo, como requisito para obtenção do grau de Mestre em Ciências

Orientador: Prof. Dr. Rui Carlos Botter

São Paulo, 5 de Junho de 2020

BANCA EXAMINADORA

Prof. Dr. Rui C. Botter

Universidade de São Paulo

Prof. Dr. Léo Tadeu Robles

UFMA

Dr ${ }^{\mathrm{a}}$. Nayara Amaral Lima de Valois

FMU 
Autorizo a reprodução e divulgação total ou parcial deste trabalho, por qualquer meio convencional ou eletrônico, para fins de estudo e pesquisa, desde que citada a fonte.

Este exemplar foi revisado e corrigido em relação à versão original, sobre responsabilidade única do autor e com a anuência de seu orientador.

São Paulo, 01 de Agosto de 2020

Assinatura do autor:

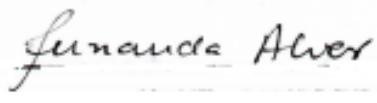

Assinatura do orientador:

\section{Catalogação-na-publicação}

ALVES, Fernanda

CARACTERIZAÇÃO DA OFERTA DE CONTÊINERES NO TRANSPORTE

MARÍTIMO BRASILEIRO DE LONGO CURSO / F. ALVES - versão corr. -- São Paulo, 2020.

156 p.

Dissertação (Mestrado) - Escola Politécnica da Universidade de São Paulo.

Departamento de Engenharia Naval e Oceânica.

1.Conteinerização 2.Navegação de longo curso 3.Logística brasileira I.Universidade de São Paulo. Escola Politécnica. Departamento de Engenharia Naval e Oceânica II.t. 


\section{Agradecimentos}

Ao Prof. Dr. Rui Carlos Botter, pela valiosa orientação, pelos ensinamentos transmitidos, pela confiança, pelo empenho em tirar a ideia do papel e principalmente pela amizade construída.

Ao Prof. Dr. Léo Tadeu Robles e à Dra . Nayara Valois, pela orientação, ensinamentos transmitidos e opiniões sinceras para aperfeiçoamento do trabalho.

Aos meus pais, pela amizade, amor, exemplo e por nunca medirem esforços para me disponibilizarem as ferramentas necessárias para abrir as boas portas que eu queria.

À minha avó Maria Alice, pelo exemplo de coragem e leveza. Uma mulher muito à frente do seu tempo que apesar dos desafios e da vida muito pobre na infância, conseguiu com muito esforço e amor, construir uma família e garantir que os filhos e netos tivessem uma educação de qualidade.

Ao meu avô Joaquim por ser meu "amigão", exemplo e companheiro de viagens e sonhos.

Ao meu padrinho, pelo exemplo de vida e amizade.

À minha mentora Livia, pela oportunidade de ter partilhado sua amizade, que muito me ensinou com seu jeito humano, racional e muito leve de ser.

Ao meu time e ao esporte, que muito me ensinaram nesses anos de faculdade e me trouxeram muito estímulo no decorrer desta jornada, colocando muita leveza e diversão nos momentos de esforço e dedicação.

Às pessoas incríveis que me ajudaram ao longo dessa jornada, os amigos que conquistei, que me ensinaram de inúmeras maneiras e deixaram esse trabalho mais leve e divertido de ser feito, porque, afinal, se há algum tipo de magia no mundo, ela está na tentativa de entender e compartilhar. 
“... que é melhor tentar coisas grandes, alcançando triunfo e glória, mesmo expondo-se temporariamente à derrota, do que formar fila com os fracos de espírito, que nem gozam muito nem sofrem muito, porque vivem nessa penumbra que não conhece vitória nem derrota”.

Abraham Lincoln.

"A maioria das ideias fundamentais é essencialmente simples e pode, de modo geral, ser expressada numa linguagem compreensível para todos".

Albert Einstein. 


\section{Resumo}

ALVES, Fernanda. Caracterização da oferta de contêineres no transporte marítimo brasileiro de longo curso. 2020. 156 f. - Universidade de São Paulo.

Entender o transporte como fundamental para o desenvolvimento de um país é premissa básica de grandes nações. O sistema de transporte e logística viabiliza a integração nacional e internacional para a movimentação de bens e pessoas. Assim, se bem planejado e estruturado, é uma ferramenta de estímulo e facilitação. Se não, se torna um gargalo para o desenvolvimento econômico-social. Em que pese a importância da existência de um sistema de transporte eficiente e articulado, contudo, nota-se no cenário brasileiro uma histórica deficiência em infraestrutura. $\mathrm{O}$ valor de $\mathrm{R} \$ 1,7$ trilhões é o investimento mínimo estimado pela CNT em 2018 para que o país tenha um sistema de transporte moderno e livre de problemas. Dentre as modalidades de transporte, o modal aquaviário é a que mais movimenta mercadorias para o comércio exterior. E, desde quando criada e implementada, a conteinerização tem tornado o transporte de mercadorias cada vez mais eficiente. Nesse contexto, a atualização das informações da distribuição espacial logística do transporte - em especial de contêineres - em escala nacional assume um papel estratégico. Assim, o presente trabalho tem por objetivo primário caracterizar a oferta de contêineres no transporte marítimo brasileiro de longo curso, caracterizando (1) a frota de navios porta contêineres que atracaram nos portos brasileiros, (2) as principais rotas das embarcações e (3) de forma estimada, a quantidade de contêineres ofertada nos portos brasileiros durante um ano - o que foi feito através da análise de uma base real de dados que monitorou a movimentação dos navios porta contêineres pelo mundo entre 2016 e 2017. A partir da análise, pôde-se estudar a efetividade da programação das linhas e rotas realizadas. Pôde-se averiguar que as rotas dos navios porta contêineres não são regulares como afirma a literatura, que existem portos principais e portos secundários, que as companhias marítimas estão se organizando de forma a afretar espaços nos navios, que os navios estão deixando de escalar em portos que haviam anunciado que escalariam, entre outras coisas que desafiam a literatura e o senso comum e que interferem no funcionamento do transporte marítimo de contêineres brasileiro.

PALAVRAS-CHAVE: Conteinerização. Navegação de longo curso. Logística brasileira. 


\begin{abstract}
ALVES, Fernanda. Caracterização da oferta de contêineres no transporte marítimo brasileiro de longo curso. 2020. 156 f. - Universidade de São Paulo.

Understanding that the transportation is fundamental to the development of a country is a basic assumption to great nations. The transportation and logistics system enables the national and international consolidation to the movement of goods and people. Therefore, if well planned and organized, is a tool of stimulation and facilitation. Otherwise, it becomes a serious bottleneck to the economic and social development of the country. Despite the importance of the existence of an efficient and articulated transportation system, however, one notes the historical infrastructure disability in the Brazilian scenario. $\mathrm{R} \$ 1,7$ trillion is the minimum investment estimated by CNT in 2018 to ensure that the country could have a modern and free of problems transportation system. Among the modes of transportation, the waterway modal is the one that moves more goods in the foreign trade. Besides that, since its creation and implementation, the containers are increasing the efficiency of the goods transport. In this respect, the update of information about the spatial distribution of the logistic transportationin particular of containers - in national level, plays a strategic role. In this way, the present study has as primary goal, characterize the Brazilian supply of containers in long distance transportation, characterizing (1) the container ships fleet that docket at the Brazilian ports, (2) the main routes of this vessels and (3) on an estimated basis, the amount of containers supplied for the Brazilian ports during one year. The study was founded on one real database that tracked the moves of all container ships in the world between 2016 and 2017. Based on the analysis, it was possible to study the effectiveness of the lines and routes schedule. It was possible to conclude that the container ship routes are not as regular as has been claimed in the literature, the Ports can be major or secondary, the maritime companies are organizing themselves in order to charter space on the vessels, the vessels are not stopping at ports where they have announced they would dock, among other things that challenge the literature and the common sense and interfere in the operation of the Brazilian container maritime transportation.
\end{abstract}

KEY WORDS: Containerization. Long distance navigation. Brazilian logistics 


\section{LISTA DE TABELAS}

Tabela 1 - Mercadorias transportadas por mar, totais anuais de 1840 a 2005 (em milhares de

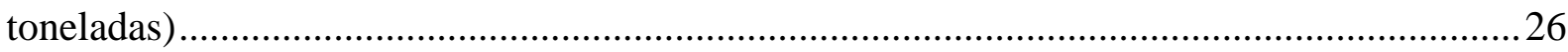

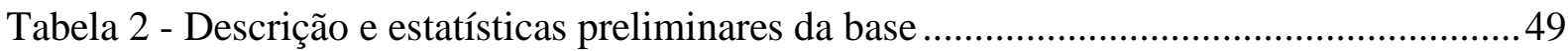

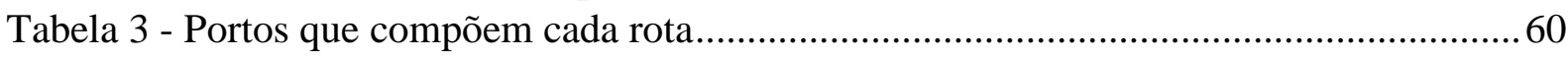

Tabela 4 - Dentre os navios escolhidos, lista de navios spots que passaram pelo Brasil .........61

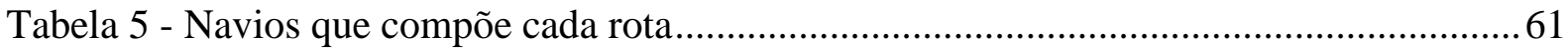

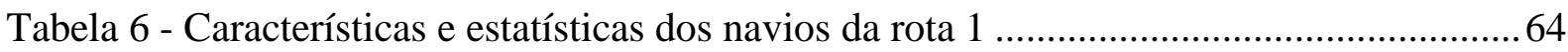

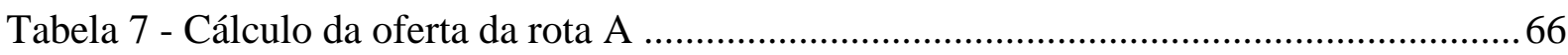

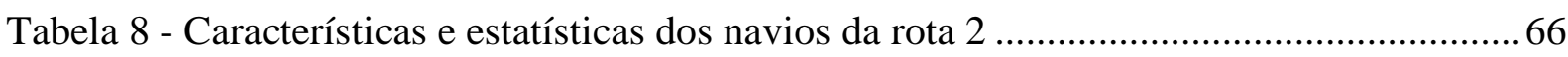

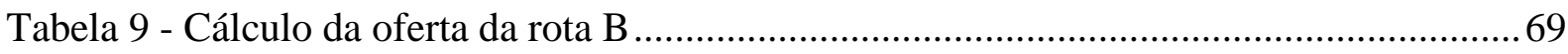

Tabela 10 - Características e estatísticas dos navios da rota C............................................... 70

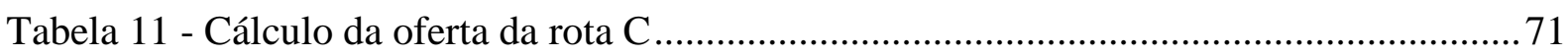

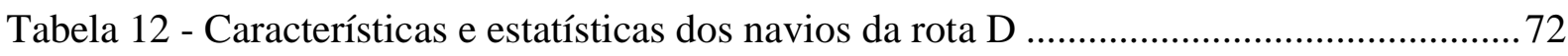

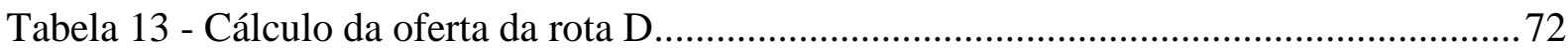

Tabela 14 - Características e estatísticas dos navios da rota E ............................................... 73

Tabela 15 - Quantidade de vezes que os navios da rota 5 anunciaram que atracariam nos

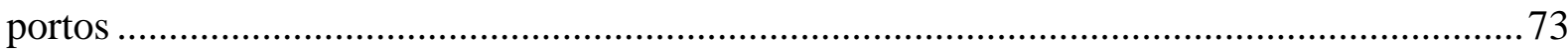

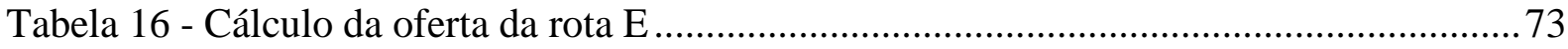

Tabela 17 - Características e estatísticas dos navios da rota seis .............................................74

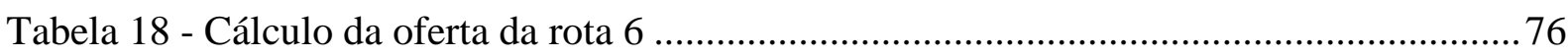

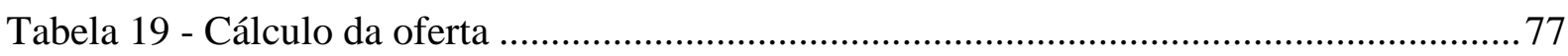

Tabela 20 - Quantidade de contêineres movimentados por navios de longo curso nas

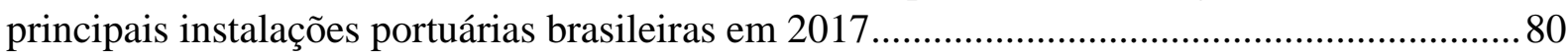

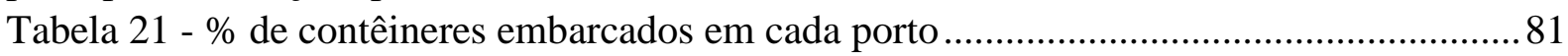

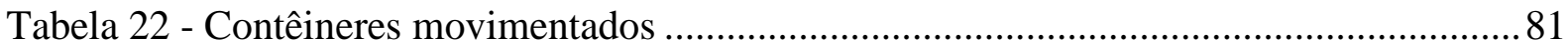

Tabela 23 - Movimentação de contêineres em cada um dos portos ......................................... 82

Tabela 24 - Movimentação de contêineres nos navios da rota $\mathrm{A}$ em relação à capacidade total

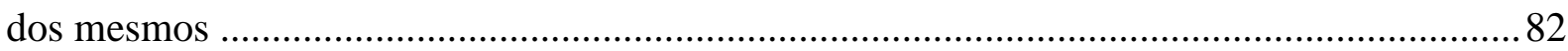

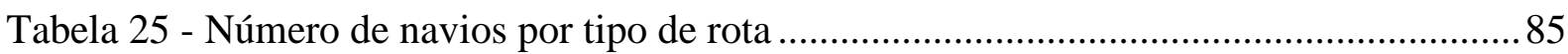

Tabela 26 - Parte da rota do Cap San Antonio durante os anos de 2016 e 2017 ......................86

Tabela 27 - Parte da rota do MSC Fiammetta, navio da rota B, durante os anos de 2016 e 2017

Tabela 28 - Quantidade de vezes que alguns dos navios do grupo Cap da rota 1 anunciaram

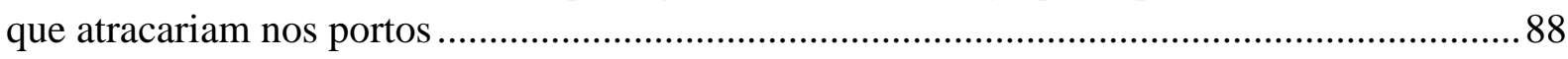

Tabela 29 - Quantidade de transportadoras por navios .................................................... 90

Tabela 30 - Exemplo de navio que deixou de escalar em um porto que havia anunciado que

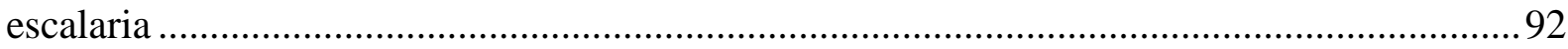

Tabela 31 - Exemplo de navio que deixou de escalar em um porto que havia anunciado que

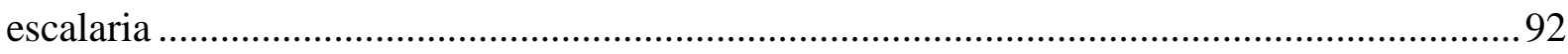

Tabela 32 - Navios porta-contêineres que passaram pela costa brasileira, seu respectivo ano de construção e sua capacidade 
Tabela 33 - Estatísticas dos navios como tempo de rota médio no Brasil e número de viagens realizadas

Tabela 34 - Quantidade de vezes que os navios da Cap da rota A anunciaram que atracariam nos portos 108

Tabela 35 - Quantidade de vezes que os navios Maersk da rota A anunciaram que atracariam nos portos

Tabela 36 - Quantidade de vezes que os navios MSC da rota B anunciaram que atracariam nos portos

Tabela 37 - Quantidade de vezes que os outros navios da rota 2 anunciaram que atracariam nos portos.

Tabela 38 - Quantidade de vezes que os navios da rota $\mathrm{C}$ anunciaram que atracariam nos portos

Tabela 39 - Quantidade de vezes que os navios da rota $\mathrm{C}$ anunciaram que atracariam nos portos

Tabela 40 - Quantidade de vezes que os navios da rota D anunciaram que atracariam nos portos

Tabela 41 - Quantidade de vezes que os navios da rota 6 anunciaram que atracariam nos portos

Tabela 42 - Quantidade de vezes que os navios spot passaram por cada porto 122

Tabela 43 - Quantidade de vezes que os navios spot passaram por cada porto 124

Tabela 44 - Quantidade de vezes que os navios spot passaram por cada porto

Tabela 45 - Quantidade de vezes que os navios spot passaram por cada porto

Tabela 46 - Quantidade de vezes que os navios spot passaram por cada porto 133

Tabela 47 - Quantidade de vezes que os navios spot passaram por cada porto

Tabela 48 - Quantidade de vezes que os navios spot passaram por cada porto 138

Tabela 49 - Quantidade de vezes que os navios spot passaram por cada porto 141

Tabela 50 - Parte da rota do Cap San Antonio, navio da rota A, durante os anos de 2016 e 2017

Tabela 51 - Parte da rota do MSC Krystal, navio da rota B, durante os anos de 2016 e 2017

Tabela 52 - Parte da rota do MSC Fiammetta, navio da rota B, durante os anos de 2016 e 2017

Tabela 53 - Parte da rota do MSC Vidhi, navio da rota B, durante os anos de 2016 e 2017.147 Tabela 54 - Parte da rota do MSC Azov, navio da rota C, durante os anos de 2016 e 2017.. 147 Tabela 55 - Parte da rota do navio Rio de Janeiro, navio da rota D, durante os anos de 2016 e 2017

Tabela 56 - Parte da rota do navio MSC Madrid durante os anos de 2016 e 2017

Tabela 57 - Parte da rota do navio Pantanal, navio da rota E, durante os anos de 2016 e 2017

Tabela 58 - Parte da rota do CMA CGM Marseille, navio da rota F, durante os anos de 2016 e 2017

Tabela 59 - Cálculo da oferta de contêineres dos navios spot que passaram pelo Brasil no período de tempo em estudo 
Tabela 60 - Lista de navios base do Porto de Santos

154

Tabela 61 - Cálculos da movimentação dos contêineres. 


\section{LISTA DE FIGURAS}

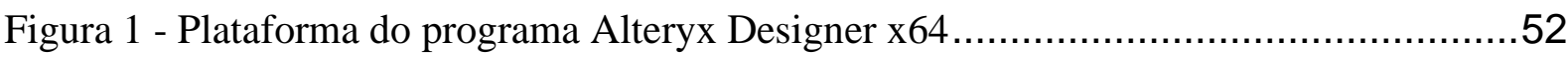

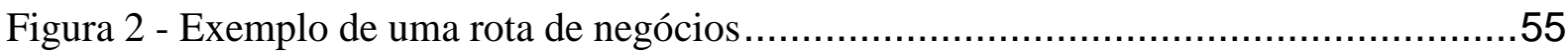

Figura 3 - Capacidade dos navios porta-contêineres que trafegaram pelo Brasil entre ago/2016 e set/2017 em TEUs

Figura 4 - Ano de construção dos navios porta-contêineres que trafegaram pelo Brasil entre ago/2016 e set/2017 em TEUs

Figura 5 - Comparação entre a capacidade dos navios (em TEUs) e o ano de construção dos mesmos

Figura 6 - Localização dos principais portos brasileiros

Figura 7 - Foto do navio Marfret Marajó .75

Figura 8 - Foto do navio CMA CGM Marseille .75 


\title{
LISTA DE ABREVIATURAS E SIGLAS
}

\author{
ABNT - Associação Brasileira de Normas Técnicas \\ ANTAQ - Agência Nacional de Transportes Aquaviários \\ CEPAL - Comissão Econômica para América Latina e Caribe \\ CNT - Confederação Nacional do Transpote \\ TEU - Twenty feet or Equivalent Unit \\ UNCTAD - United Nations Conference On Trade And Development \\ ISO - International Organization for Standardization \\ IMO - International Maritime Organization \\ TEC - Tempo Estimado de Chegada \\ TEP - Tempo Estimado de Partida
}




\section{SUMÁRIO}

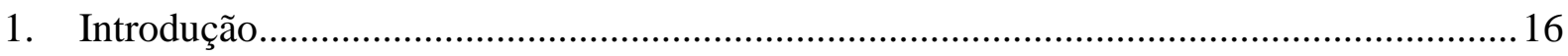

1.1. Motivação e importância do tema ........................................................................ 19

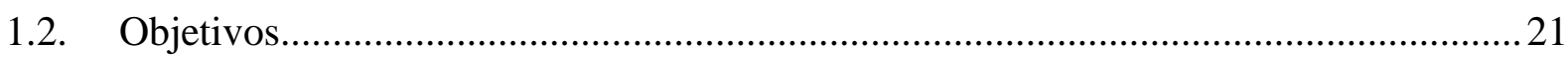

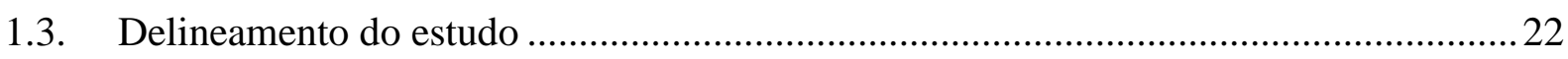

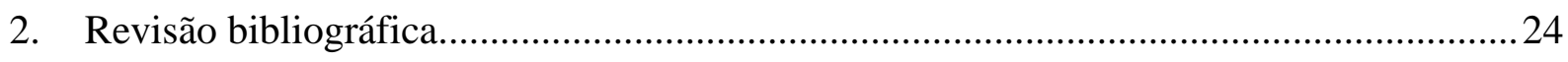

2.1. A conteinerização ............................................................................................... 24

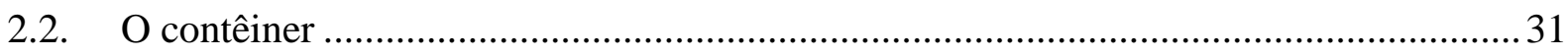

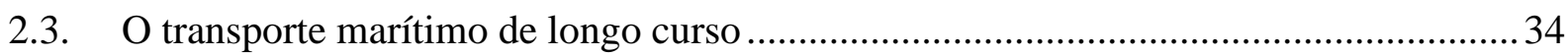

2.4. Pontos de destaque para o transporte de contêineres................................................... 37

3. Análise dos dados para caracterização da oferta dos serviços conteinerizados na costa

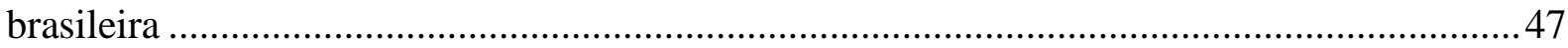

3.1. Metodologia para organização dos dados contidos na base ........................................ 48

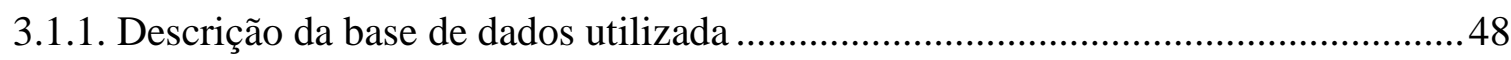

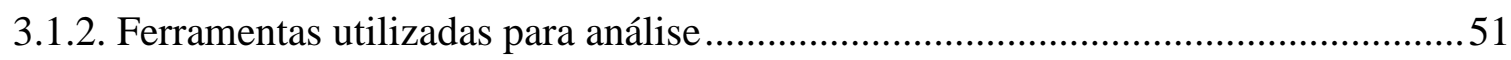

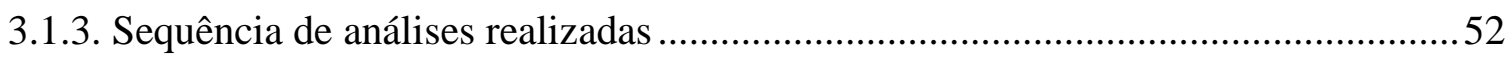

3.2. Caracterização da oferta do tráfego marítimo de navios porta-contêineres na costa

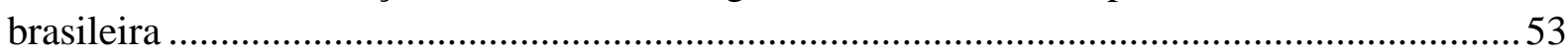

3.2.1. Descrição da frota de navios que atracou na costa brasileira.................................55

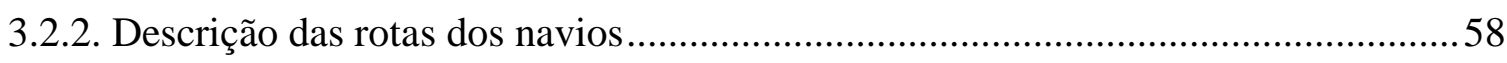

3.2.2.1. Contextualização dos portos brasileiros e identificação das rotas padrão ............58

3.2.2.1.1. Separação dos navios em dois grupos: recorrentes e "spot" com base na

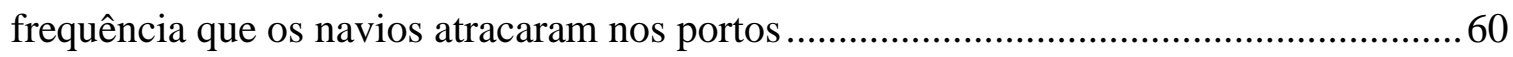

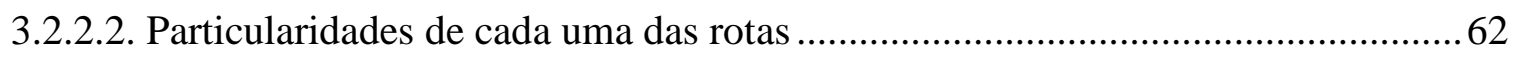

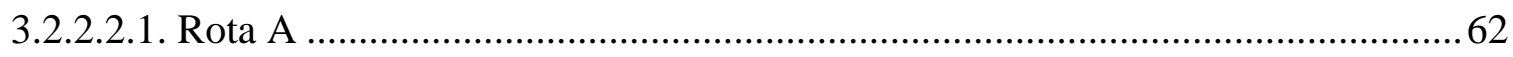

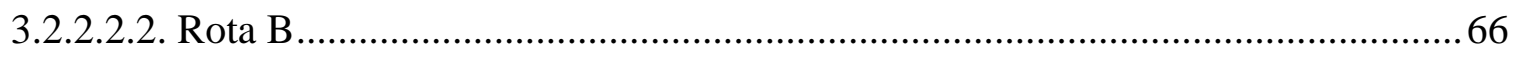

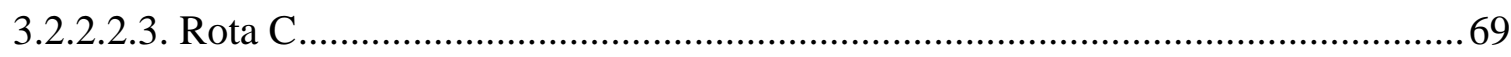

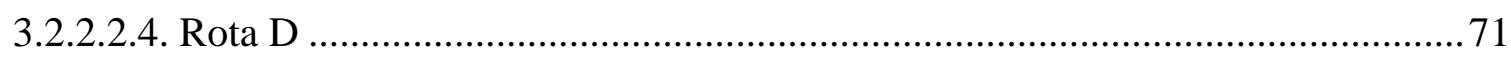

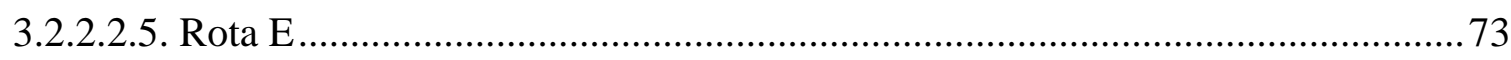

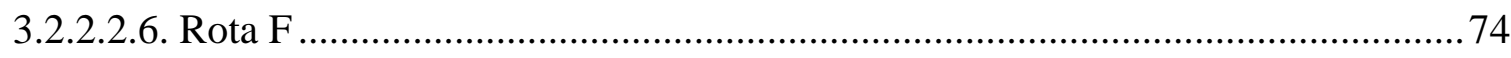

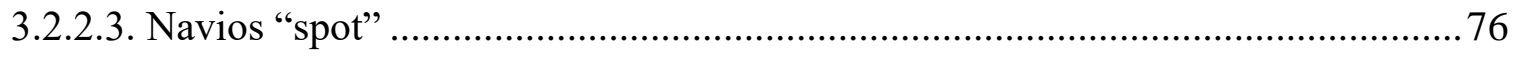

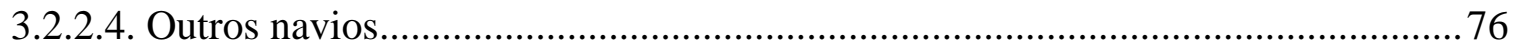


3.3. Cálculo da oferta.

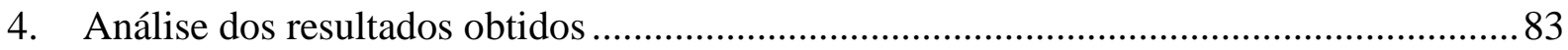

4.1. As rotas realizadas pelas embarcações não são fixas .................................................. 84

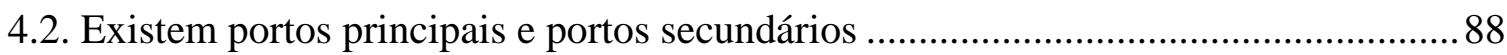

4.3. As companhias marítimas estão se organizando de forma a afretar espaços dentro das embarcações para diversas transportadoras

4.4. As companhias marítimas estão desistindo de atracar em alguns portos e isso atrapalha os pequenos e médios embarcadores ............................................................ 91

5. Considerações finais e recomendações para trabalhos futuros ..........................................96

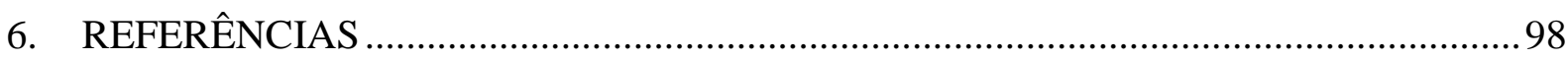

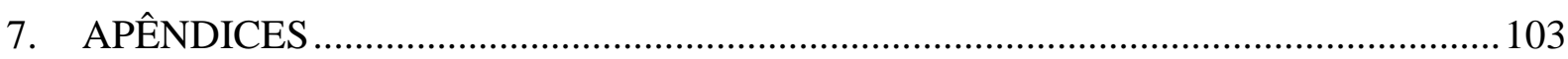

APÊNDICE A - CARACTERÍSTICAS DOS NAVIOS PORTA-CONTÊINERES QUE

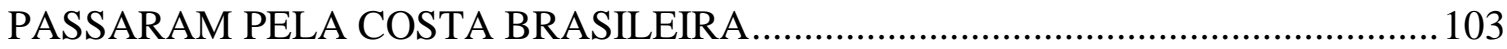

APÊNDICE B - \# DE VIAGENS, TEMPO MÉDIO DE VIAGEM NO BRASIL E TEMPO MÉDIO NO EXTERIOR DOS NAVIOS RECORRENTES QUE

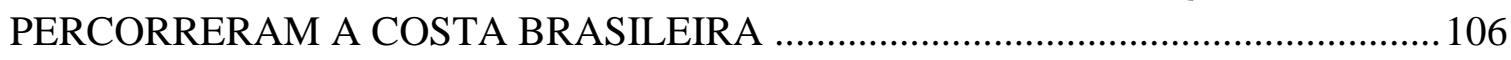

APÊNDICE C - QUANTIDADE DE VEZES QUE OS NAVIOS ANALISADOS ANUNCIARAM QUE ATRACARIAM NOS PORTOS ........................................ 108

APÊNDICE D - DESCRIÇÃO DA ROTA DOS NAVIOS SELECIONADOS............. 144 APÊNDICE E - CÁLCULO DA OFERTA PARA OS NAVIOS SPOT E “OUTROS”

APÊNDICE F - OFERTA CALCULADA X CONTÊINERES MOVIMENTADOS PARA OS NAVIOS DA ROTA A 


\section{Introdução}

O cenário econômico experenciado mundialmente de forma cada vez mais intensa ao longo do último século - caracterizado notadamente pela gradativa globalização, interconexão entre os diferentes mercados e, consequentemente, pelo grande fluxo de mercadorias - tem como reflexo o crescimento progressivo da importância do uso dos contêineres.

A adoção do moderno contentor revolucionou o sistema comercial de transportes de forma similar ao modo como a internet revolucionou os meios de comunicação. Com tal adoção, os custos de transporte reduziram. Além disso, tal processo transformou sensivelmente as cidades portuárias e seus arredores, além de contribuir decisivamente para a integração entre os mercados espalhados mundialmente, fazendo com que produtos advindos de diferentes partes do mundo se tornassem acessíveis em qualquer lugar. Nesse sentido, pode-se dizer ainda que a conteinerização teve fundamental importância no fenômeno da fragmentação do processo produtivo - uma característica fundamental da produtividade característica da economia globalizada. Assim, nas palavras de LEVINSON, M., pode-se dizer que, "os contentores tornaram o mundo mais pequeno e desenvolveram a economia mundial"1.

A principal característica da conteinerização foi a unitização, definida por BOWERSOX, CLOSS E COOPER como o agrupamento de embalagens em uma unidade física para manuseio ou transporte de materiais $^{2}$. A unitização promoveu os dois principais diferenciais da conteinerização, que são transportar diferentes tipos de cargas no mesmo modal (em um modal padronizado mundialmente) e promover uma rápida conexão terra-mar - já que o contêiner se mantém.

Uma vez que, ao lado da comunicação, o sistema de transportes é um elemento estratégico para qualquer país ou governo e que a conteinerização promove, por suas características intrínsecas, um sistema de interconexão de redes envolvendo várias combinações de modais de transporte, muitos são os benefícios para o desenvolvimento de um país em se ter

\footnotetext{
${ }^{1}$ LEVINSON, M. (2006)

${ }^{2}$ BOWERSOX, CLOSS E COOPER (2006)
} 
uma infraestrutura capaz de fomentar a utilização de contêineres para ao transporte de mercadorias.

O Brasil, no entanto, segundo uma pesquisa da BAIN \& COMPANY $^{3}$, tem uma defasagem de vários anos se comparado com os países mais desenvolvidos com relação a todo seu sistema de transporte. Essa condição restringe a nossa capacidade de transportar as riquezas produzidas, reduz a produtividade das nossas empresas e dificulta a geração de empregos e a distribuição de renda para a nossa população.

Quanto maior o crescimento econômico de um determinado país - o que equivale dizer que há uma maior presença de indústrias, atividades agrárias e comerciais - maior a demanda e a pressão sobre os meios de transporte. Nesse caso, se os meios não tiverem uma estrutura adequada para suportar essa carga, o desenvolvimento desse país encontrará maiores desafios e dificilmente se concretizará.

Dentre os meios de transporte brasileiros, é válido destacar a importância estratégica do transporte aquaviário para a economia do país. Segundo dados do Ministério da Indústria, Comércio Exterior e Serviços, em 2017, o setor movimentou, em toneladas, 98,7\% das exportações e $91,3 \%$ das importações ${ }^{4}$. Ainda assim, o potencial aquaviário do Brasil é pouco explorado e com significativas dificuldades.

Segundo a $\mathrm{CNT}^{5}$ (2018), os principais entraves ao desenvolvimento do transporte aquaviário no Brasil estão na dificuldade na obtenção de financiamentos pelos transportadores, capacitação suficiente de mão de obra, alto custo com praticagem e tripulação, deficiências nas infraestruturas das hidrovias e dos portos e terminais, falta de integração modal, baixa oferta de navios, conflito com setores concorrentes na utilização dos corpos hídricos, baixo nível de investimento público no setor, além da concorrência entre os próprios tipos de navegação que disputam entre si os mesmos recursos para operarem.

\footnotetext{
${ }^{3}$ BAIN \& COMPANY (2016)

${ }^{4}$ Segundo dados do COMEX STAT (http://comexstat.mdic.gov.br/pt/home), calculado com base na movimentação pelas vias marítimas e fluvial

${ }^{5}$ CNT é a Confederação Nacional do Transporte, entidade de representação do transporte no Brasil.
} 
Além disso, o Brasil apresenta portos com problemas de infraestrutura e investimento, tornando difícil a atracação de determinados tipos de navios em alguns portos. Segundo o IPEA ${ }^{6}$ (2009), os portos brasileiros apresentam como principais gargalos a necessidade de investimento em construção, ampliação e recuperação de infraestruturas, os acessos terrestres e a drenagem. Os investimentos na infraestrutura dos terminais portuários do Brasil são morosos e difíceis devido aos altos custos e as legislações, que tornam as aprovações complicadas e demoradas, podendo levar algumas empresas a buscarem opções para este tipo de operação em países vizinhos.

Entender a logística dos transportes do país enquanto dimensões estruturantes do território nacional e alicerces para a conexão com o mercado mundial, elaborando e divulgando estudos, por meio dos quais são disseminados conhecimentos sobre o setor e propostas alternativas para a melhoria do seu desempenho, é uma das contribuições possíveis para a análise e construção de uma nova geografia do país.

A dissertação enquadra-se nesse escopo e pretende contribuir ao esforço brasileiro de redução do atraso relativo à infraestrutura de transporte ao apresentar um estudo a respeito do transporte de contêineres no Brasil. Caracterizar o tráfego marítimo de navios porta contêineres no Brasil é uma análise que permite entender o funcionamento de uma parte da economia marítima brasileira e pode ajudar na otimização do sistema logístico como um todo a longo prazo, fornecendo conteúdo para o entendimento da situação atual, das intervenções relevantes e para identificação do potencial de desenvolvimento dessa infraestrutura de transporte.

O presente trabalho tem como objetivo primário caracterizar a oferta de contêineres no transporte marítimo de longo curso no Brasil; isto é, fornecer uma visão integrada da conteinerização, descrevendo e caracterizando (1) a frota de navios porta contêineres que atracaram nos portos brasileiros, (2) as principais rotas das embarcações e verificando padrões e regularidades e (3) de forma estimada, a quantidade de contêineres ofertada - o que foi feito através da análise de uma base real de dados que monitorou a movimentação dos navios porta contêineres pelo mundo entre 2016 e 2017. Foram 177 navios porta-contêineres apresentados e descritos, 6 rotas padrão identificadas, uma oferta de 4,4 MI de contêineres calculada e,

6 IPEA é o Instituto de Pesquisa Econômica Aplicada, uma fundação pública federal vinculada ao Ministério da Economia 
principalmente, estudos a respeito da efetividade da programação das linhas e rotas realizadas e das causas e consequências disso para o país.

As principais ferramentas utilizadas a fim de possibilitar a caracterização realizada a partir da base de dados de mais de 319.000 linhas foram os programas Excel@ da Microsoft e o programa Alteryx ${ }^{\circledR}$. Com essas ferramentas foi possível limpar os dados da base, organizálos, analisar e coletar estatísticas, calcular a capacidade do transporte a analisar os resultados obtidos. Por detrás de todos os objetivos, o principal desafio era encontrar uma alternativa de solução para expor os dados de forma integrada, clara e objetiva.

Investimentos em infraestrutura em escala nacional são, geralmente, de alto valor e de longo prazo, por isso é importante que a seleção das intervenções prioritárias seja feita com alto rigor, muito bem embasadas e segundo critérios que privilegiem os projetos de maior abrangência e impacto para a sociedade. Construir uma perspectiva multimodal, considerando as infraestruturas existentes e os atuais gargalos do país é uma abordagem crucial para o desenvolvimento social e econômico do Brasil. Como mencionado, espera-se que essa dissertação seja um recorte para concretizar uma visão da infraestrutura geral e integrada do sistema de transportes brasileiro. A reflexão é importante e pode gerar ponderações que indiquem pontos de mudança. É sabido que a análise do transporte marítimo de contêineres no Brasil depende de inúmeros outros fatores, portanto, o objetivo não é exaurir a reflexão a respeito do tema, apenas contribuir para as análises.

\subsection{Motivação e importância do tema}

Como mencionado na introdução, crucial para o desenvolvimento de um país é o seu sistema de transporte, no entanto, o Brasil tem uma infraestrutura de transporte e logística aquém do que o seu potencial permitiria e a sua malha atual é na maior parte das vezes subaproveitada, o que faz com que esse sistema - que deveria funcionar como alicerce/catalisador - funcione muitas vezes como entrave ao desenvolvimento econômico e social do país. 
Uma das alternativas de abordagem para melhorar esse contexto é o plano atual da CNT de, a partir de uma perspectiva multimodal, e considerando as infraestruturas existentes e os atuais gargalos do país, propor um plano de recomendações para a adequação e ampliação do sistema de transportes do Brasil. (CNT, 2018)

O Plano CNT de Transporte e Logística 2018 considerou as particularidades físicas, econômicas e sociais de cada região e elencou 2663 projetos essenciais para o desenvolvimento da infraestrutura de transporte nacional. As intervenções abrangem todos os modais - aéreo, aquaviário, ferroviário e rodoviário - de cargas e passageiros.

Outra abordagem, similar, é a do IBGE (Instituto Brasileiro de Geografia e Estatística), que pretende contribuir para a análise e construção de uma nova geografia do país - a partir do entendimento da logística de transporte de cargas e pessoas enquanto dimensões estruturantes da logística brasileira e das conexões intrarregionais que articulam o território nacional elaborando e divulgando estudos, por meio dos quais são disseminados conhecimentos sobre o setor e propostas alternativas para a melhoria do seu desempenho.

Segundo o IBGE nos últimos anos, com o crescimento econômico e o aumento do mercado interno, o Brasil tem uma demanda crescente por melhorias nos sistemas de transporte no sentido de diminuir os custos logísticos e tornar a produção nacional mais competitiva no exterior, bem como mais acessível ao mercado interno. Nesse contexto, a atualização das informações da distribuição espacial da logística de transporte, em escala nacional, constitui uma informação estratégica ao planejamento do presente e do futuro do território e da sociedade brasileira no mundo contemporâneo ${ }^{7}$. O que vai de encontro às ideias da $\mathrm{CNT}$, uma vez que ambas as abordagens visam estimular o desenvolvimento de um sistema de transporte eficiente e integrado, considerando os diversos modais.

Levando-se em consideração essas duas abordagens e a relevância do modal aquaviário e da conteinerização para o desenvolvimento do Brasil, o estudo pretende agregar valor ao contribuir para o esforço do país em desenvolver um sistema de transporte eficiente, oferecendo informações a respeito da logística de transporte de contêineres na costa brasileira.

\footnotetext{
${ }^{7}$ IBGE (2014)
} 
Conhecimento tal que se disseminado pode auxiliar na identificação dos atuais gargalos, consequentemente na criação de alternativas para a melhoria do seu desempenho, e nos diversos planos de recomendação para adequação e ampliação do sistema de transporte do Brasil.

A conteinerização se faz ainda mais relevante pelo seu caráter multimodal. Seu grande diferencial está em promover uma rápida conexão terra-mar, já que o contêiner se mantém. Identificar os navios que navegaram pelo Brasil, os portos nos quais esses navios atracaram e a frequência, pode auxiliar bastante na identificação de melhorias no modal.

\subsection{Objetivos}

Esse estudo tem um objetivo geral e principal e outros três objetivos específicos. Ao atingir os objetivos específicos o objetivo geral é contemplado.

O objetivo geral é caracterizar a oferta de contêineres no transporte marítimo de longo curso no Brasil. Isto é, fornecer uma visão integrada do sistema de transporte de contêineres no Brasil - o que será realizado a partir da análise de uma base de dados real que registrou a movimentação de navios porta contêineres no mundo entre Agosto de 2016 e Setembro de 2017, filtrando apenas as embarcações que transitaram pela costa brasileira.

Esse objetivo engloba principalmente a organização dos dados para apresentá-los de forma simples, clara e objetiva e torná-los úteis para análises posteriores a respeito da situação atual e do potencial do sistema de transporte marítimo de contêineres brasileiro; afinal, a geração de mudanças depende de um diagnóstico do problema.

O objetivo principal pode ser dividido em três objetivos específicos que descrevem cada uma das etapas do trabalho:

- Caracterizar a oferta de navios porta contêineres pela capacidade dos navios;

- Caracterizar algumas das principais rotas percorridas pelos navios no Brasil;

- Calcular a oferta de contêineres no Brasil - o estoque da capacidade de transporte; 
Posteriormente são realizadas análises para verificar a relação programação (linhas/rotas) com o realizado por navio e levantados questionamentos a respeito do funcionamento dessa modalidade de transporte no país. Com vistas a descrever e caracterizar a forma como se dá a oferta de contêineres no transporte marítimo brasileiro, convém versar a respeito dos seguintes questionamentos:

1. As rotas que os navios realizam são regulares como afirma a literatura?

2. Os navios atracam em todos os portos com a mesma frequência ou existem portos principais e portos secundários?

3. Se existem duas companhias marítimas com serviços a serem entregues nos portos da mesma rota em datas muito próximas, será que ambas iniciarão suas rotas com os navios pouco ocupados ao invés de juntar suas mercadorias e fazer com que um navio sirva as duas empresas?

4. Caso não haja demanda suficiente em um determinado porto, será que o navio atracará no porto de qualquer forma ou segue direto para o próximo porto da rota para otimizar o serviço?

Como não poderia deixar de ser, os objetivos não têm a pretensão de exaurir a discussão, cuja complexidade extrapola o escopo deste estudo, mas apenas se propõe a lançar luz sobre relevante tema que aflige o segmento de transporte marítimo de longo curso e, quiçá, permitir uma melhor compreensão e contextualização da temática, cuja definição é de suma importância para a paulatina inserção e consolidação do Brasil no mercado internacional.

\subsection{Delineamento do estudo}

Esse estudo está dividido em capítulos, descritos a seguir.

O primeiro capítulo (a) introduz o problema proposto, (b) justifica a importância a este atribuída, mostrando rapidamente qual o conteúdo encontrado ao longo deste estudo e exibindo características que tornam o tema relevante, e, por fim, (c) explicita os objetivos do estudo. 
O segundo capítulo apresenta uma revisão bibliográfica do tema estudado com definições e regras encontradas na literatura pesquisada, apresenta uma contextualização a respeito dos contêineres, a importância do modal e como aconteceu o surgimento do mesmo, explica a importância do transporte marítimo, assim como descreve a relevância de alguns fatores como o tempo para garantir a eficiência da conteinerização.

O capítulo três se concentra em explicar tanto a metodologia para realizar a organização dos dados coletados, o que inclui uma descrição da base original, as ferramentas utilizadas, a sequência de análises e as dificuldades encontradas para o tratamento dos dados, quanto à caracterização da oferta do serviço de contêineres no Brasil com base nos dados analisados: um entendimento da frota de navios e das rotas que os mesmos realizaram, o cálculo da oferta da movimentação de contêineres no período de tempo registrado pela base e, por fim, as investigações que puderam ser inferidas com o diagnóstico realizado e a visão integrada apresentada. O desafio era apresentar os dados de forma clara, simples e objetiva para que eles possam se tornar um diagnóstico desse sistema de transportes útil para investigações posteriores.

Por fim, o capítulo quatro apresenta uma análise dos resultados obtidos e o cinco, uma conclusão a respeito do estudo realizado e sugestões para futuras investigações a respeito do sistema de transporte marítimo de contêineres no Brasil. 


\title{
2. Revisão bibliográfica
}

Este capítulo prepara o leitor para um entendimento do problema abordado, a importância da conteinerização para o desenvolvimento dos países e de seu comércio exterior, assim como as dificuldades dessa técnica de transporte.

As principais definições utilizadas neste estudo são:

Contêiner: "tipo de embalagem que acondiciona a carga a ser transportada". (BARCO, 1998)

Conteinerização: uma técnica utilizada para o transporte de mercadorias em unidades unitizadas de acomodação dos produtos e que, através de uma modulagem padrão, permitem a manipulação por um sistema integrado entre diferentes modais (rodoviário, ferroviário ou hidroviário $)^{8}$.

Como afirma Nobre (2006), o contêiner representou uma mudança profunda nos negócios de transporte marítimo, ou como escreveu Peter Drucker:

\begin{abstract}
Não havia tecnologia na ideia de tirar uma carroceria de caminhão de suas rodas e colocá-la num navio cargueiro. Esta inovação, 'o contêiner', não surgiu de uma tecnologia qualquer, mas sim de uma nova percepção do 'navio cargueiro' como sendo um equipamento para manipular cargas, e não simplesmente um 'navio', significando, com isto, que o mais importante era tornar o mais curto possível o tempo de atracação no porto. Mas esta inovação, aparentemente trivial, quase quadruplicou a produtividade dos cargueiros marítimos de carga geral e, provavelmente, salvou a marinha mercante. Sem ela, a tremenda extensão do comércio mundial nos útimos 40 anos - o maior crescimento dentre as mais importantes atividades econômicas jamais registrado não poderia possivelmente ter ocorrido. (DRUCKER, 2003, p. 40)
\end{abstract}

\subsection{A conteinerização}

A partir do século XIX, como consequência das mudanças introduzidas pela revolução industrial, percebeu-se transformações significativas no ramo do transporte marítimo, de forma que é possível identificar uma série de inovações que revolucionaram a marinha mercante.

Primeiro, os motores a vapor, que libertaram os navios da dependência dos ventos; segundo, os cascos de ferro, que protegiam a carga e permitiram a construção de navios maiores; terceiro, as

\footnotetext{
${ }^{8}$ BARCO (1998)
} 
hélices, que aumentaram a navegabilidade dos navios mercantes; e quarto, a rede telegráfica oceânica, que permitiu a comunicação entre os comerciantes e os proprietários de navios em todo o mundo 9 .

Como consequência desse cenário, percebe-se uma transição entre um sistema livre gerenciado por comerciantes, para uma indústria rigorosamente gerenciada e especializada no transporte de cargas por mar.

Além de cargas, o desenvolvimento do comércio global impulsionava o tráfego de passageiros e de correspondências, havendo uma pressão comercial tremenda para aumentar a velocidade desses serviços ${ }^{10}$.

Em suma, a indústria marítima configurou-se como um sistema novo, o que lhe conferiu maior velocidade e eficiência. Tal processo culminou no aumento gradativo da importância do transporte marítimo de mercadorias como é possível verificar na tabela abaixo, que evidencia um aumento incontestável no número total de mercadorias transportadas anualmente entre 1840 e $2005^{11}$.

O crescimento continuou acelerado depois de 2005, segundo a UNCTAD ${ }^{12}$, no ano de 2010, foram movimentadas 8.409 milhões de toneladas de carga por via marítima e em 2016 foram movimentas 10.287 milhões de toneladas.

\footnotetext{
${ }^{9}$ STOPFORD (2009)

${ }^{10}$ STOPFORD (2009)

11 STOPFORD (2009)

12 UNCTAD (2017)
} 
Tabela 1 - Mercadorias transportadas por mar, totais anuais de 1840 a 2005 (em milhares de toneladas)

\begin{tabular}{|c|c|c|c|c|c|c|}
\hline & 1840 & 1887 & 1950 & 1960 & 1975 & 2005 \\
\hline Petróleo bruto & & 2.700 & 182.000 & 456.000 & 1.367 .000 & 1.885 .000 \\
\hline Derivados do petróleo & & n.d. & n.d. & n.d. & 253.700 & 671.000 \\
\hline Gás liquefeito & & n.d. & n.d. & n.d. & 21 & 179.000 \\
\hline Total do petróleo & & 2.700 & 216.000 & 456.000 & 1.620 .700 & 2.556 .000 \\
\hline Minério de ferro & & & & 101.139 & 291.918 & 661.000 \\
\hline Carvão & & & & 46.188 & 127.368 & 680.000 \\
\hline Grão & 1.400 & 49.300 & & 16.126 & 137.202 & 206.000 \\
\hline Bauxita e alumina & 1.900 & 19.200 & & 15.961 & 41.187 & 68.000 \\
\hline Fosfato & & & & 18.134 & 37.576 & 31.000 \\
\hline Total & & & & 227.548 & 635.251 & 1.646 .000 \\
\hline Ferro e aço & 1.100 & 11.800 & & & 55.000 & 226.000 \\
\hline Madeira & 4.100 & 12.100 & & & 77.500 & 170.000 \\
\hline Açúcar & 700 & 4.400 & & & 17.291 & 48.000 \\
\hline Sal & 800 & 1.300 & & & 8.700 & 24.000 \\
\hline Algodão & 400 & 1.800 & & & 2.315 & 7.800 \\
\hline$L \tilde{a}$ & 20 & 350 & & & 1.200 & \\
\hline Juta & & 600 & & & 450 & 382 \\
\hline Carne & & 700 & & & 3.200 & 26.640 \\
\hline Café & 200 & 600 & & & 3.134 & 5.080 \\
\hline Vinho & 200 & 1.400 & & & 1.217 & \\
\hline Outras & 9.180 & 33.750 & 334.000 & 426.452 & 646.042 & 2.412 .098 \\
\hline $\begin{array}{l}\text { Total do comércio transportado } \\
\text { por via marítima }\end{array}$ & 20.000 & 137.300 & 550.000 & 1.110 .000 & 3.072 .000 & 7.122 .000 \\
\hline $\begin{array}{l}\text { Aumento em relação ao período } \\
\text { anterior em } \%\end{array}$ & & $4,2 \%$ & $2,2 \%$ & $7,3 \%$ & $7,0 \%$ & $2,8 \%$ \\
\hline
\end{tabular}

Fonte: (STOPFORD, 2009, p. 52). As estatísticas não são precisamente comparáveis e fornecem somente uma ideia aproximada dos desenvolvimentos do comércio durante esse longo período.

Assim como a revolução industrial introduziu inovações que auxiliaram no desenvolvimento do transporte marítimo, também teve como consequência um expressivo crescimento do comércio, aumentando a complexidade das operações de transporte, e fazendo 
com que o mercado fosse dividido em três segmentos: navios de passageiros de linhas regulares, navios de carga de linhas regulares e navios de transporte marítimo de linhas não regulares.

Enquanto os navios de carga de linhas não regulares transportavam cargas a granel, como carvão e grãos, em contratações por viagem, os navios de linhas regulares geralmente carregavam também cargas especiais como frigoríficas e cargas pesadas e eram operados em programações regulares e, com frequência, concebidos para rotas específicas.

Pode-se dizer então, que a melhoria da tecnologia dos navios a vapor possibilitou aos proprietários de navios oferecerem serviços programados.

Os serviços programados foram um primeiro passo para a eficiência que seria alcançada anos depois, no entanto, não foram suficientes para evitar a substituição dos navios graneleiros de linhas regulares.

Os projetistas dos navios graneleiros de linhas regulares preocupavam-se em construir navios flexíveis que pudessem transportar todo tipo de carga. Mas, embora flexíveis, esses navios requeriam trabalho e capital intensos.

Dessa forma, a partir da década de 1950, quando a força de trabalho encareceu e a produtividade começou a se tornar mais importante do que a flexibilidade, as carências dos navios cargueiros de linhas regulares começaram a se tornar evidentes.

Além dessas duas mudanças, outras transformações ocorreram: muitas colônias se tornaram independentes, o que fez com que muitas companhias regulares perdessem sua posição privilegiada, grande parte do tráfego foi transferido para navios graneleiros a taxas de frete que os navios cargueiros de linhas regulares não podiam praticar e, principalmente, houve uma mudança no padrão do comércio - num contexto de rápido crescimento da economia entre 1950-60 nos centros industriais prósperos, os embarcadores precisavam de transporte rápido, confiável e seguro.

As carências dos navios cargueiros de linhas regulares se tornaram cada vez mais evidentes, o custo, a complexidade, o baixo desempenho eram obstáculos do sistema de entrega. E os embarcadores não queriam esperar enquanto sua carga passava por diversos portos e 
chegava muito avariada. Por fim, proprietários de navios perceberam que eram caros e gastavam demasiado tempo em porto.

Para as companhias de linhas regulares, o gerenciamento dos navios cargueiros de linhas regulares tornou-se igualmente ingrato. Os seus caros navios "dedicados" consumiam até $50 \%$ do seu tempo de estadia em porto, o que amarrava o capital e limitava o escopo das economias de escala, porque duplicar a capacidade dos navios cargueiros de linhas regulares significava quase que duplicar o seu tempo de estadia em porto. Não havia muito a fazer pelos gestores nem pelos arquitetos navais para aliviar os problemas fundamentais do empacotamento de uma carga geral de 10.000 a 15.000 toneladas no porão do navio. Durante a década de 1960, as despesas dos navios, os problemas do manuseio da carga e a segregação da sua carga do resto do sistema de transporte tornaram os navios cargueiros de linhas regulares tecnologicamente obsoletos. Isso resultou numa reestruturação completa do sistema de transporte marítimo, a segregação por sistema de linhas regulares e não regulares foi substituída pelos segmentos de negócio do granel, dos serviços especializados, dos contêineres e do frete aéreo. (STOPFORD, 2009)

A principal solução foi unitizar a carga geral utilizando contêineres. A padronização permitiu que as companhias de linhas regulares investissem em sistemas mecanizados e equipamentos que automatizaram o processo e aumentaram a produtividade. Esse procedimento era basicamente uma extensão da linha de produção.

Ainda segundo Stopford (2009), o sistema de conteinerização foi desenvolvido por Malcolm McLean, um homem de negócios dos EUA sem qualquer experiência no transporte marítimo, em face do ceticismo geral que existia na indústria de linhas regulares. McLean havia passado a vida em uma empresa de transporte rodoviário, até que em 1955, vendeu-a e comprou por U\$S 6 milhões uma empresa que detinha alguns navios tanques. Após a compra, McLean mandou equipar um dos navios-tanque com um pavimento sobre estacas, sobre as linhas de carga e sobre os coletores, para transportar sessenta contêineres de 35 pés. Em 26 de abril de 1956, 58 contêineres venceram a viagem de 3000 milhas de Nova Jersey para Houston e os custos de manuseio foram de 16 centavos por tonelada, comparados com os US\$ 5,83 por tonelada que se gastavam no manuseio de carga geral fracionada.

Apesar do sucesso comercial, algumas companhias de linhas regulares estabelecidas mantiveram-se céticas, tinham dúvidas acerca do novo sistema, mesmo porque inicialmente o abordaram como um desenvolvimento das suas operações de linhas regulares existentes, e não como um novo sistema, com navios porta-contêineres dedicados, terminais, redes de distribuição rodoviária e uma frota de contêineres. 
Por conta da dimensão do investimento necessário, foram investigados muitos outros sistemas menos radicais, contudo, as economias não funcionaram na prática. Após a insistência de McLean e aceitação das principais companhias de navegação, para arcar com esses investimentos formaram-se consórcios.

A conteinerização era composta por três principais componentes: o produto transportado (a carga era embalada de forma padronizada para ser manuseada ao longo de toda a operação), o investimento necessário para criar um sistema integrado com veículos em cada etapa da cadeia de transporte capazes de manusear a mesma unidade-padrão e, por último, o investimento em equipamento de manuseio de carga de alta velocidade para transferir o contêiner entre as etapas.

O desenvolvimento da frota de navios foi um desafio técnico, porque a estrutura, com escotilhas abertas, era muito diferente dos navios cargueiros de linhas regulares que os estaleiros navais estavam habituados a construir.

Além disso, os portos de linhas regulares tinham milhas de cais que se apoiavam em armazéns, onde os navios estariam atracados por semanas manuseando a carga. Os terminais de contêineres eram dois ou três berços, servidos por gruas de pórticos, apoiados por uma área de armazenagem a céu aberto. (STOPFORD, 2009)

O movimento dentro dos terminais também foi mecanizado, utilizando empilhadeiras, aranhas ou, em alguns casos, sistemas de pórticos automáticos. As velocidades variam de porto para porto, indo de quinze a trinta movimentos por hora. (STOPFORD, 2009)

O resultado foi uma melhoria muito grande na produtividade: enquanto os berços de carga geral manuseavam anualmente de 100.000 a 150.000 toneladas de carga ao ano, os novos terminais manuseavam de 1 a 2 milhões de toneladas de carga ao ano em cada berço. (STOPFORD, 2009)

A compatibilidade intermodal também foi bastante melhorada, porque o contêiner propriamente dito é padronizado. Quarenta anos depois, em 2007, os contêineres dominavam mais de três quartos do tráfego de carga geral, e 4.300 navios porta-contêineres com uma capacidade de 10,6 milhões de TEU transportavam anualmente mais de 1 bilhão de toneladas de carga entre 360 portos. (STOPFORD, 2009) 
Por fim, para garantir a eficiência do sistema, foi necessário um acordo internacional sobre as dimensões padronizadas dos contêineres. Eventualmente, a ISO ${ }^{13}$ desenvolveu normas que se aplicavam às dimensões, resistência dos cantos, resistência do chão, testes de estrutura e ao peso bruto do contêiner.

A conteinerização foi muito bem-sucedida no seu objetivo principal de reduzir o tempo de estadia no porto. Além disso, alterou a forma como as companhias de linhas regulares operavam, uma vez que permitiu que o serviço "porta a porta" fosse parte essencial do negócio. A atenção não poderia ser mais tão focada nos navios e nas operações de transporte marítimo, surgiu a necessidade de gerenciar simultaneamente as pernadas terrestres e marítimas do transporte, introduzindo a logística no negócio e mudando a abordagem da precificação.

Por outro lado, o negócio consolidou-se em poucas companhias, uma vez que eram necessários altos investimentos, tornando-se o setor mais concentrado do negócio do transporte marítimo e os portos movimentados do tempo da carga geral foram substituídos pelos terminais de contêineres com pouco pessoal e poucos navios.

O objetivo principal passava a ser o lucro por unidade de tempo, e não a minimização de custos (RONEN D. , 2002).

O mercado de linhas regulares havia se tornado uma indústria importante a partir de 1870 e, desde a conferência de Calcutá em 1875 esse mercado foi caracterizado por acordos fraudulentos, conhecidos como conferências dos navios, que denotam acordos formais entre companhias de linhas regulares em uma rota, sempre determinando (possivelmente de forma discriminatória) preços, e muitas vezes centralizando lucros e receitas, gerenciando capacidade, alocando rotas e oferecendo descontos por lealdade.

As explicações para a existência das conferências dos navios se devem a duas categorias: carteis monopolistas e competição destrutiva. (SJOSTROM, 2004)

Desta forma, até meados da década de 80, o mercado operava através de conferências de frete fechada. No entanto, na segunda metade da década, com a conteinerização, iniciou-se um processo de desregulamentação, quebrando o monopólio das conferências, e abrindo espaço

13 ISO é a sigla de International Organization for Standardization ou Organização Internacional para Padronização 
para a formação de grandes empresas globais de navegação, pertencentes a países desenvolvidos ou estatais de países em desenvolvimento, como a estatal chinesa Cosco. Apesar de o mercado ser aparentemente aberto, ainda persistem diversas legislações protecionistas por parte de vários países. (SJOSTROM, 2004)

Esses foram os principais impactos para a indústria marítima. Porém para a economia mundial as consequências foram ainda mais profundas. $\mathrm{O}$ transporte entre regiões que era antes lento, caro, não confiável e com uma grande probabilidade de objetos frágeis serem roubados ou avariados durante o processo morros de carga e descarga, tornou-se rápido, seguro e incrivelmente barato. Como resultado, a distância ao mercado e os custos de transporte tornaram-se aspectos menos importantes quando se considerava a localização da indústria e da manufatura. Portanto, assim que a rede de contêineres cresceu nas décadas de 1980 e 1990, cresceu também a globalização.

\subsection{O contêiner}

O contêiner representou uma mudança profunda nos negócios de transporte marítimo, tornou o mundo menor e a economia maior, com a possibilidade de transportar cargas unitizadas. (LEVINSON, 2006).

As características intrínsecas do contêiner reduzem os custos logísticos totais, ao mesmo tempo em que potencializam níveis de (Nobre, 2006 apud BROOKS, BUTTON, \& NIJKAMP, 2002) pela padronização de funcionalidades e de quesitos operacionais para movimentação, ao encontro do conceito de logística integrada, isto é, a otimização dos elementos logísticos, a saber, transporte, armazenagem, embalagem, manuseio, sistemas de informações, inventários e questões fiscais (BOWERSOX, CLOSS, \& COOPER, 2006).

Segundo Nobre (2006, p. 59), a técnica do transporte por contêineres consiste em acomodar quantidades de carga no interior de recipientes metálicos fortes, de dimensões padronizadas e reutilizáveis, e transportar estes recipientes lacrados até seus destinatários, de maneira a garantir que esta carga chegue íntegra ao seu destino. Além disso, os contêineres 
oferecem vantagens como: as camadas inferiores da carga não sofrem "esmagamento" e os contêineres podem ser movimentados sob quaisquer condições climáticas.

Cada contêiner ao entrar no tráfego recebe uma identificação e uma numeração, com registro no BIC14. Por padrão ISO, esta identificação é composta de uma sigla ou prefixo com quatro letras, seguido da numeração que com de sete dígitos, sendo o último o dígito de controle. As três primeiras letras são determinadas a critério das empresas proprietárias dos contêineres, normalmente correspondendo às inicias de seus nomes. A última letra é sempre a letra "U" e significa unity (unidade). Os primeiros três dígitos identificam a série e os três seguintes identificam o contêiner em relação a esta série. O último dígito é chamado de dígito verificador e é determinado a partir de um cálculo considerando a sigla (valores são atribuídos a cada letra) e os seis primeiros dígitos. Este cálculo impede que dois contêineres de mesma sigla possuam numeração igual. Exemplos de numeração: Triton - TTNU5906043, Hamburg Süd SUDU5073190. (NOBRE, A gestão logística do contêiner vazio, 2006)

Os contêineres são de propriedade dos armadores, empresas de leasing ou dos próprios embarcadores. Estima-se que a frota em circulação tenha a seguinte distribuição $70 \%$ armadores, $27 \%$ empresas de leasing e 3\% dos próprios embarcadores. Estes percentuais são difundidos pelo setor, não tendo sido encontrada e a informação em fontes oficiais ${ }^{15}$.

As empresas de leasing têm por atividade essencial (core business) alugar contêineres para os armadores, os contratos podem ser de longo prazo (com opção de compra ao final) ou de curto prazo, e as bases negociais entre as Leasings e os Armadores dependem das relações comerciais ${ }^{16}$.

As taxas diárias (per diem) de aluguel (on hire) variam para cada tipo de contêiner. Compõe o preço do aluguel de contêiner a taxa diária de aluguel, o prazo do aluguel (on hire), locais e quantidades mensais para as devoluções das unidades alugadas, multa diária em caso de atraso na devolução (off hire), preço da unidade ou tabela com seu valor depreciativo em caso de perda total da unidade e demais taxas que se façam acordadas entre as partes ${ }^{17}$.

\footnotetext{
${ }^{14}$ BIC - Bureau International des Contêiners et du Transport Intermodal. Organização não governamental, com sede em Paris, com 1200 membros reunidos num plano mundial para a conteinerização e o transporte intermodal, tais como: fabricantes, transportadores, empresas de leasing, embarcadores, consignitários de carga. ${ }^{15}$ NOBRE (2006)

${ }^{16}$ NOBRE (2006)

${ }^{17}$ NOBRE (2006)
} 
Durante o período em que o contêiner permanecer alugado, a responsabilidade sobre a unidade passa a ser do armador locatário, que em caso de avarias deve repará-lo de acordo com as normas internacionais de reparos - IICL ${ }^{18}$.

A frota de contêineres representa volume expressivo de investimento por parte dos armadores. Estima-se o preço de um contêiner novo de 20 pés dry em torno de US\$2.300, um de 40 pés dry em torno de US\$3.700, sendo que o contêiner reefer pode chegar a mais de US\$ 60.000 , dependendo das especificações e exigências da carga a ser transportada ${ }^{19}$.

Os tipos de contêiner, segundo Nobre ${ }^{20}$, mais utilizados no transporte marítimo são:

- Dry Van 20': contêiner completamente fechado destinado ao transporte de carga seca: caixas de papelão, sacas de café e fardos de madeira.

- Dry Van 40': contêiner completamente fechado destinado ao transporte de carga seca com pouco peso e muito volume: fardos de tabaco, caixas de chocolate, caixas de doces.

- Dry Van 40' High Cubic (HC): contêiner completamente fechado destinado ao transporte de carga seca com grande volume: fardos de algodão (Padrão ABRAPA Associação Brasileira dos Produtores de Algodão), caixas de fogão, bobinas de papel craft. O HC é um pé (aprox. $30 \mathrm{~cm}$ ) mais alto do que o contêiner de Dry Van 40', do qual se originou.

- Open Top: contêiner destinado ao transporte de cargas que excedem a altura de um contêiner padrão ISO (International Organization for Standardization). Não possui teto sua parte superior é coberta por uma lona chamada Tarpaulin, sustentada por travessas presas as longarinas superiores laterais. A longarina superior traseira é removível para facilitar a entrada da carga.

- Reefer: contêiner isolado termicamente com maquinário integrado e controle eletrônico de temperatura, destinado ao transporte de cargas que necessitam de aquecimento,

18 NOBRE (2006)

${ }^{19}$ NOBRE (2006)

${ }^{20}$ NOBRE (2006) 
resfriamento ou congelamento: produtos industrializados de origem animal como carne de aves e bovinos, produtos de origem vegetal como frutas e plantas.

- Normalmente os contêineres reefer operam em uma faixa de temperatura entre $-25^{\circ} \mathrm{Ce}$ $+25^{\circ} \mathrm{C}$ Existem os chamados super freezers que conseguem manter temperaturas de até $-60^{\circ} \mathrm{C}$

- Tank: contêiner completamente fechado e isolado termicamente destinado ao transporte de granéis líquidos, químicos ou alimentícios: óleo de soja, álcool, ácido sulfúrico.

- Flat Rack: contêiner aberto nas laterais e teto destinado ao transporte de cargas que excedem as dimensões de largura e altura e também cargas muito pesadas: tratores, blocos de granito. O propósito deste tipo de contêiner é permitir que cargas disformes sejam embarcadas em navios fully contêiner.

- Plataform: contêiner aberto em sua totalidade destinado ao transporte de cargas que excedem as dimensões padrão ISO de altura, largura e comprimento: máquinas colheitadeiras, pás aeólicas, peças de usinas hidroelétricas. O propósito deste contêiner é o mesmo do contêiner Flat

- Rack, permitir que cargas disformes sejam embarcadas em navios fully container.

O contêiner, pelas suas propriedades de uso, assume uma condição dual, isto é: enquanto em trânsito marítimo, é um equipamento do navio, enquanto em terra, passa para a condição de embalagem das cargas dos embarcadores.

\subsection{O transporte marítimo de longo curso}

A água é o mais antigo meio de transporte e o transporte internacional tem sua concentração no transporte marítimo. O mercado de cargas do transporte marítimo se apresenta 
como a maior artéria dos negócios internacionais, tem sido e continuará como principal modo de transporte no comércio entre as nações ${ }^{21}$.

O desenvolvimento e o crescimento do tráfego marítimo estão associados à movimentação de cargas decorrente da demanda e da liberação dos negócios internacionais; dos aperfeiçoamentos técnicos dos navios e terminais portuários; e das economias de escala fortalecida pela conteinerização (OCDE, 2005).

O transporte tem como fatores específicos distância, volume, densidade, facilidade de acondicionamento e facilidade de manuseio (BOWERSOX, CLOSS, \& COOPER, 2006).

Como dito por Vieira (2003, p. 13), “Transporte nada mais é do que o translado de uma mercadoria de um lugar a outro e sua necessidade está diretamente relacionada com as atividades de comércio", ou seja, a demanda por transporte é dependente da demanda por mercadorias. (SANTOS, 2006)

O comércio internacional, para que aconteça, depende de diversas modalidades de transporte e no contexto associado, o transporte marítimo de cargas se caracteriza como a maior artéria dos negócios internacionais. O mesmo tem sido, se apresenta e continuará como principal modo de transporte no comércio entre as nações (NOBRE \& SANTOS, O mercado de transporte marítimo: especialização, evolução e os reflexos na logística internacional, 2005)

O transporte de cargas com a globalização vem sendo objeto de inovações e especializações contínuas. As cargas podem ser transportadas de acordo com suas características adequando-se aos diversos modais (SANTOS, 2006).

O sistema de transporte pode ser classificado, segundo Bowersox, Closs e Cooper (2006, p. 282), em cinco modais ${ }^{22}$ básicos: ferroviário, rodoviário, hidroviário, dutoviário e aéreo; ao que concordam Lambert, Stock e Vantine (1998, p. 167).

Assim como afirma Santos (2006, p. 71), a escolha do modal de transporte deve levar em consideração diversos fatores, entre outros: redução de custos; economias de escala; agilidade e flexibilidade dos processos de movimentação; menor quantidade de avarias; maior

\footnotetext{
${ }^{21}$ NOBRE (2006)

${ }^{22}$ Um modal identifica um método ou forma básica de transporte (BOWERSOX, CLOSS, \& COOPER, 2006)
} 
segurança no transporte e manuseio da carga; padronização na unidade de carga transportada; menor tempo de operação; distância a ser percorrida. Fatores cobertos com vantagens pelo modal hidroviário, quando se trata de comércio internacional de cargas conteinerizadas.

A possibilidade de navegar em águas profundas (mares e oceanos) e/ou águas interiores (rios e lagos), com a grande capacidade volumétrica por viagem dos navios, faz com que o transporte hidroviário se torne o principal modelo utilizado no comércio entre as nações. (SANTOS, 2006)

Os navios têm a capacidade de transportar grandes quantidades de carga. É o modal que, individualmente, por embarcação, possui a maior capacidade de transporte e quando considerado o total de embarcações confirma a maior capacidade total instalada (NOBRE, 2006).

Dada a evolução tecnológica e a consequente modernização das embarcações, os tipos de navio foram se especializando para atender as especificidades dos tipos de carga.

Quanto ao tipo de mercado, o transporte marítimo está estruturado em três modalidades de prestação de serviços: Liner operations, Tramp shipping e Industrial operations (RONEN D. , 2002, p. 4).

- Industrial operations são os proprietários da carga e da frota.

- Tramp shipping em linguagem marítima significa navio independente sem linha regular de navegação; navio a frete. É o contrário do Liner (LUNA, 2003).

- Liner operations ou Liner Shipping (operadores de linhas regulares) são aqueles que obedecem a um itinerário predeterminado e repetitivo (rotas) com portos e escalas fixas, cumpridas com grande aproximação (VIEIRA, 2003)

As linhas regulares, Liner Shipping, têm por objetivo maximizar lucros por unidade de tempo e não a minimização de custos. O retorno da operação depende da qualidade do serviço em relação à frequência, tempo de viagem, confiança e segurança oferecidas nos serviços prestados (RONEN D. , 2002, p. 6). 


\subsection{Pontos de destaque para o transporte de contêineres}

Muitos são os estudos que tentam desvendar a complexidade do planejamento do transporte de contêineres que envolvem distribuir as frotas de navios, direcionar as rotas e agendar os navios da melhor forma possível.

Como visto, uma companhia Liner oferece um serviço regular de transporte através de um conjunto de rotas, cada uma especificada por um conjunto de portos entre duas ou mais regiões intercontinentais e cada rota envolve uma ou mais viagens que devem ser vendidas durante um horizonte de tempo ${ }^{23}$.

Uma viagem consiste numa sequência de escalas nos portos com carregamento e descarregamento dos navios, começando no porto onde o navio carrega sua primeira carga e terminando onde o navio descarrega sua última carga (BRANCHINI, ARMENTANO, \& MORABITO, 2015).

As características das viagens são estipuladas em um contrato de afretamento entre o remetente e a companhia marítima. Cada viagem contratual exige um horário de partida, uma duração estimada, a taxa do frete, os portos que serão visitados e o mínimo ou máximo de mercados de determinada natureza entre portos. Outro tipo de viagem, as viagens "spot", envolvem um contrato para mover uma única carga de um porto para o outro em um futuro próximo (BRANCHINI, ARMENTANO, \& MORABITO, 2015).

Os navios têm diferentes capacidades e podem transportar diferentes tipos de carga. Tempo de navegação, carregamento e descarregamento devem variar conforme navio e conforme a incumbência designada ao navio. $\mathrm{O}$ tempo que o navio gasta em um porto inclui o tempo de espera para atracar no berço, resolver a documentação, armazenamento e carregamento e descarregamento das cargas ${ }^{24}$.

Vários níveis de decisão, incluindo o estratégico, o tático e o operacional, existem em uma companhia marítima de serviços lineares. Decisões estratégicas incluem design da rede de

\footnotetext{
${ }^{23}$ BRANCHINI, ARMENTANO, \& MORABITO (2015)
}

${ }^{24}$ STOPFORD (2009) 
navios, alianças estratégicas e tamanho das frotas. Decisões táticas envolvem a distribuição de frotas, otimização da velocidade, construção do cronograma e determinação da frequência. Decisões operacionais, por sua vez, incluem o agendamento e o roteamento das cargas, entre outras coisas (CHEAITOU; LARBI; HAMDAN, 2018) e (MENG et al., 2014).

Devido à complexidade do tema, muitos são os trabalhos a respeito do planejamento dos serviços lineares, que estudam como determinar a distribuição das frotas, direcionar as rotas ou agendar os navios, quais os principais fatores a serem considerados e como priorizá-los ou ponderá-los diante de algumas incertezas.

Em BRANCHINI, ARMENTANO, \& MORABITO ${ }^{25}$, é abordado o tema de roteamento e distribuição de frotas em serviços liner com viagens "spot". Os autores estão interessados em coordenar as decisões de atribuição de navios para as viagens contratuais e "spot" com a determinação das rotas e horários dos navios com o objetivo de maximizar os lucros.

As pesquisas extensivas de (RONEN D., 1993, 2002), (CHRISTIANSEN, FAGERHOLT, \& NYGREEN et al, 2013) e (CHRISTIANSEN, FAGERHOLT, \& RONEN, 2004) são referências importantes, porque cobrem quatro décadas de evolução da literatura sobre problemas de roteamento e agendamento de navios, assim como relatam problemas de planejamento.

MENG et al. ${ }^{26}$ fornece uma revisão dos últimos 30 anos do roteamento e agendamento de navios porta-contêineres em companhias marítimas Liner, no nível estratégico, tático e operacional. KJELDSEN ${ }^{27}$ desenvolveu um sistema de classificação com 18 problemas característicos desse tipo.

TRAN \& HAASIS ${ }^{28}$ conduziram uma extensa pesquisa sobre otimização de redes dessas companhias focando nas três principais categorias: roteamento dos contêineres, atribuição e agendamento dos navios e design da rede. A literatura a respeito do transporte marítimo tem crescido significantemente devido ao crescimento da frota mundial e do comércio mundial que trouxeram à tona novos e complexos problemas.

\footnotetext{
25 BRANCHINI, ARMENTANO, \& MORABITO, (2015)

${ }^{26}$ MENG et al. (2014)

${ }^{27}$ KJELDSEN, (2011)

28 TRAN \& HAASIS, (2015)
} 
CHEAITOU, LARBI, \& HAMDAN ${ }^{29}$, em seu artigo, por exemplo, endereçam o problema estratégico e técnico de conciliar rotas integradas de navios contêineres, otimização de velocidade e dimensionamento de frotas. Os autores assumem que as decisões sobre quais portos incluir nas redes e as decisões sobre a frota e o tamanho dos navios fazem parte de um nível estratégico.

A maioria das companhias marítimas garante escalas semanais nos portos incluídos nos serviços. Essas obrigações requerem certo número de embarcações para serem usadas no serviço que depende da distância do ciclo e da velocidade de navegação. Reduzir o número de embarcações distribuídas em um serviço pode reduzir os custos de operação. Consequentemente, decisões quanto às rotas dos navios, otimizar a velocidade e dimensionar a frota são relacionadas e tem um impacto significante na eficiência operacional das companhias.

MASAELI, ALUMUR, \& BOOKBINDER ${ }^{30}$, por sua vez, exploram a questão do impacto da programação dos navios em problemas relacionados à localização de hubs ${ }^{31}$. No artigo, os autores objetivam determinar a localização ótima para os hubs, suas redes estruturais, e o número de despachos para serem operados nas suas redes, assim como, o período de tempo de despachar cada veiculo do hub. Eles testam o impacto das decisões de agendamento dos navios e custos de controladoria nas configurações dos hubs, decisões das rotas e custo total da rede.

NG \& LIN ${ }^{32}$ buscam examinar como distribuir a frota de navios com serviços lineares ao ter informações incompletas a respeito da demanda. Os autores tratam do problema de distribuição da frota, que consiste em maximizar os lucros ao decidir o número e os tipos de navios para serem distribuídos nas diversas rotas. Esse problema foi examinado primeiramente no trabalho de PERAKIS \& JARAMILLO ${ }^{33}$, que formularam um modelo de programação para esse problema de planejamento assumindo a demanda conhecida. Apesar de ignorado, é sabido que a demanda tem um grande impacto nas decisões de transporte (WALLER, SCHOFER, \& ZILIASKOPOULOS, 2001). No entanto, apenas em 2010, o primeiro estudo que considerava

\footnotetext{
${ }^{29}$ CHEAITOU, LARBI, \& HAMDAN (2018)

${ }^{30}$ MASAELI, ALUMUR, \& BOOKBINDER, (2018)

31 Sistema de portos centrais como pontos de articulação entre a linha principal e redes de alimentação.

32 NG \& LIN, (2018)

33 PERAKIS \& JARAMILLO, (1991)
} 
a demanda como estocástica (MENG \& WANG, 2010), com a motivação de que sub-ótimas decisões estariam sendo feitas ao desconsiderar esse ponto (NG M. , 2015).

Para esclarecer a influência de pontos como um bom planejamento da rota, escolha do tamanho da frota de navios, número de escala nos portos, etc, na eficiência da conteinerização, Notteboom $^{34}$ explica a relevância do fator tempo nos serviços de linhas regulares.

Gerenciar o tempo é crucial no design dos serviços de linhas regulares. O aumento do congestionamento dos portos e problemas de infraestrutura são motivos que impedem as companhias de serviços lineares de entregarem serviços impecáveis para os seus clientes. Tempo de espera e atrasos colocam pressão na confiabilidade dos horários e podem incluir custos de logística para os clientes. $\mathrm{O}$ autor lida com o fator tempo no design de serviços regulares e operações. Ele não apenas estuda as causas de insegurança nos cronogramas, mas também discute o enorme conjunto de medidas e ferramentas de planejamento que as linhas de navios implementam para maximizar a credibilidade dos cronogramas.

As companhias marítimas de linhas regulares desenvolveram, ou pelo menos objetivam desenvolver, redes de serviços caracterizadas pelos custos baixos de operação, altas frequências, rápido tempo em trânsito e ambos, rigorosos e confiáveis cronogramas de viagem. Comum a complexidade crescente em redes globais de transporte, gerenciar o fator tempo no design e operação Liner não é uma tarefa fácil.

Segundo Bell e Bichou ${ }^{35}$, o tempo de carregamento influencia a confiabilidade da programação de horários. Quando os horários estão instáveis, pode ocorrer uma aglomeração de navios, guiando a serviços menos frequentes operados por embarcações amontoadas. No entanto, nem sempre aperfeiçoar a taxa nas quais os navios são carregados e descarregados através de modelos analíticos e simulações é a melhor solução, para que essa otimização seja colocada em prática, faz-se necessário também entender primeiro se há certo equilibro entre a oferta e a demanda nos portos. Pode não ser muito eficiente otimizar o tempo de carregamento dos portos se a oferta é maior que a demanda, por exemplo.

\footnotetext{
${ }^{34}$ Notteboom (2006)

${ }^{35}$ Bell e Bichou (2008)
} 
Congestionamento dos portos é apenas um dos vários fatores que podem prejudicar os cronogramas e afetar negativamente a confiabilidade dos mesmos. Perder alguns minutos resulta em perder dólares para as companhias marítimas e seus clientes, e em um mercado competitivo de companhias marítimas todo dólar conta. (NOTTEBOOM, The time factor in liner shipping services, 2006)

Em seu artigo, Notteboom ${ }^{36}$ discute os parâmetros de design assim como os diversos padrões que as transportadoras oferecem para atender as exigências dos clientes com relação à frequência, tempo em trânsito e preço, oferece uma análise do tempo em trânsito e da confiabilidade do cronograma, fontes de atraso são identificadas e avaliadas. Por fim, discute o conjunto de medidas que objetiva reduzir a insegurança dos cronogramas. Os conceitos desenvolvidos e problemas discutidos no artigo foram aplicados em operações na rota da Ásia, em particular entre os portos da China, Japão e Coréia e os centros de carregamento na faixa Hamburg-Le Havre no norte da Europa.

Segundo CHRISTIANSEN, FAGERHOLT, \& RONEN ${ }^{37}$, o design das programações é frequentemente referenciado como um problema de planejamento estratégico para companhias marítimas. Ao desenhar um serviço regular, as transportadoras estão considerando inicialmente o mercado que será servido.

Existem três principais decisões inter-relacionadas para os planejadores do serviço: (1) a frequência do serviço; (2) o tamanho da frota, dos navios e o mix da frota; (3) o número de escala nos portos ${ }^{38}$.

As transportadoras oferecem as redes que elas consideram convenientes oferecerem, no entanto, ao mesmo tempo têm que prover os serviços que seus clientes querem em termos de frequência, acessibilidade direta e tempo em trânsito. Essa tensão entre roteamento e demanda é importante ${ }^{39}$.

Os planejadores devem direcionar os fluxos através dos caminhos ótimos para o sistema, com os mais baixos custos para a rede sendo alcançados por rotas indiretas via hubs ou

\footnotetext{
${ }^{36}$ Notteboom (2006)

37 CHRISTIANSEN, FAGERHOLT, \& RONEN, (2004)

38 (NOTTEBOOM, The time factor in liner shipping services, 2006)

39 (NOTTEBOOM, The time factor in liner shipping services, 2006)
} 
miscigenação de fluxos. Entretanto, quanto mais eficiente a rede do ponto de vista das transportadoras, menos conveniente essa rede pode ser para as necessidades do remetente. Os remetentes podem evitar rotas indiretas, abrindo possibilidade para que outras companhias marítimas entrem no mercado ${ }^{40}$.

Ao se observar os desenvolvimentos recentes nas linhas regulares, existe uma evidente movimentação para reduzir o número de navios em operação em relação à receita geral. A produtividade vem sendo otimizada pelo uso de navios maiores e mais rápidos, mas tão importante quanto isso, são as criações de novos padrões operacionais e de cooperação entre companhias marítimas ${ }^{41}$.

As companhias marítimas têm um enorme conjunto de padrões à sua disposição, todos com seus provados méritos em determinadas circunstâncias. Serviços triangulares, pendulares e outras formas de complexidade são alternados com serviços "end-to-end" (serviço completo do início ao fim) e outras adaptações para melhor se adequar as necessidades das transportadoras (para terminologia nos tipos de serviços regulares ver (NOTTEBOOM, 2004)).

Essa complexidade crescente das redes de serviços regulares está de acordo com as descobertas de ROBINSON ${ }^{42}$. Se referindo à reestruturação do hub da Ásia, ele argumenta que o sistema de portos centrais como pontos articuladores entre a linha principal e redes de alimentação está sendo substituído por um grupo de redes hierarquicamente organizadas refletindo custos e níveis de eficiência do mercado. Redes com maior demanda por serviço terão mais portos para fazer escala e embarcações maiores. $\mathrm{O}$ aumento do volume desta forma pode guiar a uma segmentação dos serviços regulares e a hierarquia nos hubs.

$\mathrm{Na}$ busca por maximizar o transporte, "relaying" (retransmissão) tem tido um papel importante, particularmente para carregar excedentes. Entretanto, apenas algumas companhias construíram redes que envolvem efetivamente a integração das rotas de comércio. Maersk Sealand é um exemplo disso. Os navios "post-Panamax" utilizados nos serviços pendulares, não servem apenas os cronogramas do Far East e Europe/North America, mas também agem como um "conveyor belt" entre uma serie de hubs controlados - Algeciras, Salalah e Tanjung

\footnotetext{
40 (NOTTEBOOM, The time factor in liner shipping services, 2006)

41 (NOTTEBOOM, The time factor in liner shipping services, 2006)

42 ROBINSON (1998)
} 
Pelepas. Praticamente toda a carga que vem do West Africa passa por Algeciras, de onde malhas semanais irradiam. A maior diferença entre a Maerks Sealand's fazendo isso e outras transportadoras é a integração entre as partes. Diferentes serviços se encaixam para providenciar boas conexões e operações nos hubs principais.

A outra única companhia a fazer isso é a MSC que tem vários serviços de retransmissão e lançou diversos pêndulos (West Australia, Singapore, Thailand). Ambos, Maersk Sealand e MSC, têm escala para gerar carga suficiente para usar os navios que elas empregam. Para as alianças estratégicas e agrupamentos (Grand Alliance, New World Alliance, etc), tal estratégia não é tão conveniente dado as diferentes prioridades dos membros. (NOTTEBOOM, 2006)

Os padrões de serviço na rota East Asia-Europe mudaram substancialmente recentemente como um resultado do boom econômico da china. Os portos chineses alcançaram um tremendo crescimento no rendimento dos contêineres. A atração de retornos potenciais guiou os operadores de terminais internacionais tais como Hutchison, PSA Corp e APM Terminals a colocar dinheiro nos portos chineses, proporcionando infraestrutura e serviços com padrões globais (NOTTEBOOM, 2006).

O aumento do volume e a melhora na infraestrutura dos portos chineses tornaram mais atrativos para as transportadoras aumentar o número de "direct calls" (viagens sem escala em portos intermediários), ao invés de enviar os contêineres por comedouros para os hubs regionais (MEYERICK, 2004). Essa mudança nos serviços regulares que chegam e saem da China afetou principalmente de forma negativa o sistema coreano de portos de contêineres que perdeu demanda (NOTTEBOOM, 2006).

O sistema de transporte de contêineres é estruturado por prazos curtos. As companhias marítimas fortaleceram o foco em desenvolver serviços regulares com curto tempo em trânsito, combinados com o alto grau de confiabilidade nos horários. Com o objetivo de entregar serviços impecáveis aos seus clientes, as companhias marítimas se esforçam para cumprir os horários anunciados nos cronogramas oficiais (NOTTEBOOM, 2006).

Atrasos não apenas diminuem a confiabilidade do serviço como podem acarretar custos logísticos aos clientes como consequência de custos adicionais no inventário e em alguns casos custos adicionais de produção (exemplo: produção para devido a um atraso na entrega de 
material). Isso sem dizer que os atrasos também incluem custos para as companhias marítimas na forma de custos extras operacionais, conectados, por exemplo, a tempo improdutivo da embarcação ou reagendamento das mesmas (NOTTEBOOM, 2006).

Por exemplo, um pequeno número de atrasos pode ser um fator decisivo em um mercado maduro no qual as companhias não são muito diferentes e os tempos em transito são similares.

O tempo em trânsito pode ser definido como o número de dias navegados de porto a porto. Em cadeias logísticas maiores, o tempo em trânsito considera o tempo total de porto a porto, portanto incluindo tempos de permanência nos terminais e necessários para carregamento e descarregamento. Um elemento crucial no tempo em trânsito de porto a porto é a ordem dos portos na malha. Na prática, as decisões das companhias marítimas na ordem dos portos são influenciadas por várias determinantes comerciais e operacionais, incluindo a carga, a distribuição dos contêineres no interior, o local de atracação dos navios, os acessos náuticos, etc (NOTTEBOOM, 2006).

Companhias marítimas, operadoras de terminais e também os remetentes estão avisados da grande variação do tempo em trânsito como consequência da ordem dos portos na rota. Para maximizar os níveis do serviço, vários navios desenvolveram diversas opções de frete, que oscilam entre mais barata para as opções com maiores tempo em trânsito (NOTTEBOOM, 2006).

Oferecer tempos de trânsito pequenos é um fator competitivo nas linhas regulares, em particular quando as mercadorias envolvidas são sensíveis ao tempo. Exemplos típicos seriam alimentos perecíveis e mercadorias com um ciclo de vida curto ou elevada técnica ou depreciação (fashion, computadores, etc).

Atrasos e perdas de tempo em operações de navios podem ter diversas causas, que podem ser classificadas em quatro grupos segundo Notteboom (2006):

- Operações dos terminais:

- Congestionamento nos portos/terminais ou tempos de espera inesperados antes de atracar ou começar a carregar/descarregar. Em algumas situações, o 
congestionamento nos portos pode prejudicar completamente o cronograma dos navios.

- Produtividade do porto/terminal abaixo das expectativas. Atualmente, a produtividade nos terminais de 120 TEU por navio por hora não é mais uma exceção, gerando maiores expectativas em termos de disponibilidade dos guindastes pórticos e das operações no cais. Ao agendar uma malha e calcular os tempos em trânsito, as companhias levam em consideração ao desempenho do terminal, além da flexibilidade dos operadores dos terminais ao lidar com situações de emergência. Congestionamento nos portos e produtividade são incentivos para as companhias assegurarem capacidade em portos chave. $\mathrm{Na}$ Europa, por exemplo, as companhias marítimas têm entrado no mercado através do desenvolvimento de terminais dedicados em centros principais de carregamento.

- Acesso aos canais

- Acesso aos canais sempre constitui um gargalo no sistema marítimo global de transportes. Prejuízos no acesso ao porto aparecem de várias formas, como por exemplo, inesperados tempos de espera devido à irregularidade na pilotagem ou nos serviços de reboque (disponibilidade de piloto ou barco rebocador).

- Passagens marítimas

- Passagens marítimas tais como o canal de Suez ou do Panamá tem um importante papel nos cronogramas.

○ O canal de Suez é composto por $163 \mathrm{~km}$ de canal no Egito entre o Porto Said no Mediterrâneo e Suez no Mar Vermelho. Navios com até 22m de calada podem atravessar a passagem desde a reforma em 2015. O trajeto demora entre 11 e 16 horas para ser realizados

- Oportunidades 
- Isso inclui tempos de espera inesperados devido às circunstâncias climáticas, problemas mecânicos ou em algum lugar de parada. Demoram dias, às vezes até semanas para terminais na Europa e na costa dos EUA se recuperarem de prejuízos no cronograma devido ao mau tempo.

- Como um serviço de linhas regulares consiste em um grupo de viagens de embarcações individuais, atrasos em um dos segmentos têm um efeito cascata.

$\mathrm{O}$ artigo analisou o fator tempo no design de serviços lineares e operações, como as companhias lidam com os trade-offs ${ }^{43}$ de gerenciar o fator tempo no design dos serviços regulares e discutiu as medidas e ferramentas de planejamento que as transportadoras usam para maximizar a segurança dos horários.

Gerenciar o fator de tempo no design e operação das companhias marítimas é um desafio importante. Redes logísticas complexas emergiram demandando altas frequências, baixos tempos em trânsito e alta confiança nos cronogramas com o menor custo possível. Mas ao mesmo tempo, o crescimento rápido no volume das cargas nos anos recentes conduziu um congestionamento no porto tornando essa uma das principais causas de atraso.

Companhias marítimas de transporte estão constantemente balanceando fatores tais como o risco de chegadas atrasadas, a minimização do cronograma e tempos atuais em trânsito. Eles empregam um grande conjunto de medidas para garantir a segurança dos horários e os tempos em trânsito o máximo possível. No entanto, as transportadoras lidam de forma diferente com potenciais prejuízos aos cronogramas de serviço.

${ }^{43}$ Trade-off significa troca compulsória. 


\section{Análise dos dados para caracterização da oferta dos serviços conteinerizados na costa brasileira}

Para atingir o objetivo geral de caracterizar a oferta de contêineres no transporte marítimo de longo curso brasileiro, foi necessário tratar a base de dados que continha a movimentação dos navios porta contêineres no mundo de Agosto de 2016 a Setembro de 2017.

O tratamento começou com a filtragem dos dados e portos de interesse: foram selecionados 14 portos de interesse (portos brasileiros e alguns dos mais importantes portos latino americanos) e analisados 177 navios (que atendiam o critério de serem navios de longo curso que atracaram em algum porto brasileiro durante o período de estudo).

A próxima etapa consistia em responder a seguinte pergunta: “como expor os dados de forma simples e objetiva, permitindo também ao leitor obter uma visão integrada do sistema de serviços conteinerizados na costa brasileira"? Para isso, foi necessário tratar os dados de forma a explicar a caracterização sob a perspectiva de dois grandes subsistemas: navios e rotas. Cada qual foi apresentado separadamente, dando ênfase ao que é mais relevante de cada sistema.

Com essa organização e tratamento dos dados, foi possível atingir os objetivos secundários da dissertação de caracterizar a oferta de navios porta contêineres especificando sua capacidade e ano de construção, caracterizar as rotas percorridas pelos navios e calcular a oferta de contêineres oferecida pelos navios que vieram ao Brasil.

Com esses dados: capacidade dos navios, rotas percorridas pelos mesmos e frequência de ciclos no Brasil, foi possível calcular a oferta estimada de contêineres no transporte marítimo brasileiro, terceiro e último objetivo secundário da dissertação.

Por fim, na conclusão, serão apresentadas as investigações que puderam ser inferidas com a análise da base de dados, como por exemplo, a análise da relação da programação (linhas/rotas) com o realizado por navio no Brasil.

Antes de apresentar os resultados dos objetivos almejados, explicaremos a metodologia para organização dos dados. 


\subsection{Metodologia para organização dos dados contidos na base}

Para realização do trabalho foi realizada uma pesquisa quantitativa. Com base nos números e dados coletados foi possível validar hipóteses e levantar questionamentos e conclusões.

A fim de explicar o tratamento realizado na base para organização dos dados coletados, esse item concentra-se em apresentar:

- A base de dados original utilizada - descrição dos dados que continha a base original utilizada para gerar a caracterização.

- As ferramentas - descrição das ferramentas utilizadas para realizar a análise dos dados.

- Sequência de análises realizadas - descrição das etapas das análises que foram realizadas para chegar à apresentação final.

\subsubsection{Descrição da base de dados utilizada}

A caracterização do transporte marítimo de contêineres na costa brasileira foi efetuada com os dados de uma base real da Linescape ${ }^{44}$. A base contém informações de Agosto de 2016 até começo de Setembro de 2017, a respeito da movimentação de navios porta contêineres no mundo e tem mais de trezentas e dezenove mil linhas, o que exige técnicas de análise de big data para limpeza e classificação das informações.

O conteúdo das colunas contidas na base original está apresentado na Tabela 2.

\footnotetext{
${ }^{44}$ Linescape é uma empresa que fornece base de dados para buscas de rotas e programações de navios porta conteineres no oceano. A base foi adquirida para o período de estudo.
} 
Tabela 2 - Descrição e estatísticas preliminares da base

\begin{tabular}{|c|c|c|}
\hline Código & Descrição & $\begin{array}{l}\text { Estatísticas listadas na } \\
\text { base }\end{array}$ \\
\hline carrier_code & \multirow{2}{*}{$\begin{array}{l}\text { Nome e Código da } \\
\text { transportadora }\end{array}$} & \multirow[t]{2}{*}{58 empresas } \\
\hline carrier_name & & \\
\hline service_code & \multirow[t]{2}{*}{ Nome e Código do serviço } & \multirow[t]{2}{*}{1.050 serviços } \\
\hline service_name & & \\
\hline vessel_imo & \multirow{3}{*}{$\begin{array}{l}\text { Nome do navio, Código IMO } \\
\text { e número da viagem }\end{array}$} & \multirow[t]{3}{*}{2.140 navios } \\
\hline vessel_name & & \\
\hline vessel_voyage & & \\
\hline port_code & \multirow{4}{*}{$\begin{array}{l}\text { Código e nome do porto para } \\
\text { cada eta e etd. }\end{array}$} & \multirow[t]{4}{*}{467 portos } \\
\hline port_name & & \\
\hline port_eta & & \\
\hline port_etd & & \\
\hline Date off & Data do anúncio & $\begin{array}{l}\text { Período de } 1 \text { de Agosto } \\
\text { de } 2016 \text { até } 7 \text { de } \\
\text { Setembro de } 2017\end{array}$ \\
\hline
\end{tabular}

Fonte: autoria própria

Ou seja, a base apresenta para cada navio porta contêiner que se movimentou entre $1^{\circ}$ de Agosto de 2016 e 7 de Setembro de 2017, qual nome e código da transportadora e do serviço que ele estava carregando, qual seu nome, seu código $\mathrm{IMO}^{45}$ e o número das viagens que ele estava realizando, qual o código e nome do porto no qual ele atracou e desatracou, as respectivas datas de atracamento e partida e a data que ele anunciou a viagem (isso é relevante principalmente quando os navios atrasavam ou alteravam sua programação e precisavam anunciar a nova data de atracação no porto). Dado isso, fez-se necessário analisar

45 IMO é a Organização Marítima Internacional, criada em 1948 como um organismo especializado na estrutura da ONU, com o objetivo de promover mecanismos de colaboração e segurança marítima, prevenção da poluição e remoção dos óbices ao tráfego marítimo. 
simultaneamente o $\mathrm{TEC}^{46}$, $\mathrm{TEP}^{47}$ e o Date off para perfeita caracterização da rota e entender qual o dia correto de atracação da embarcação no porto.

As dificuldades encontradas para a limpeza da base são as dificuldades comuns a qualquer análise de uma base de dados muito extensa e que não está sendo analisada pela mesma pessoa que a gerou (ou que programou o sistema para gerá-la). Algumas informações foram geradas de forma duplicada, alguns nomes sofreram alguma alteração, o que dificulta um pouco a análise e pode tornar os dados mais frágeis. Dito isto, foi necessário limpar os dados com muita cautela, muitas vezes até de forma manual analisando linha por linha.

Um ponto teve que ser tratado com maior cautela: o fato de que cada vez que o navio atrasava sua chegada no porto ou alterava sua rota, ele anunciava um novo TEC e "Date off", e a base criava uma nova linha com as alterações nessas datas ou nos portos, mas sem apagar os dados anteriores. Os navios anunciavam inicialmente o dia que atracariam no porto e se durante o trajeto atrasassem essa atracação por algum motivo, anunciavam a nova data de atracação.

Muitos navios anunciaram diversas datas planejadas para atracar em um determinado porto, até, por fim, anunciarem a data na qual ocorreu de fato a atracação. O que, em algumas situações pode parecer que o navio atracou duas vezes no mesmo porto em um curto espaço de tempo, mas na verdade ele apenas alterou sua data de atracação. Para definir a data real de atracação do navio, foi utilizada sempre a última data anunciada. Encontrar essa data exigiu uma complexa análise dos dados, utilizando incialmente o Alteryx e posteriormente, no Excel.

Para análise dos dados foram utilizadas ferramentas que possibilitaram tratar cada um dos navios separadamente e determinar a sequência de portos e a data de viagem dos navios. A fim de extrair as informações da base de dados, foram utilizados os programas Excel e Alteryx. Com eles foi possível limpar os dados da base, organizá-los, analisar e coletar estatísticas, calcular a capacidade do transporte e analisar os resultados obtidos como veremos no próximo item.

\footnotetext{
46 TEC: Tempo estimado de chegada

47 TEP: Tempo estimado de partida
} 


\subsubsection{Ferramentas utilizadas para análise}

As principais ferramentas utilizadas para tornar possível a caracterização do tráfego marítimo de contêineres a partir da base de dados foram os programas Excel® da Microsoft e a plataforma do Alteryx $®$.

O Excel® é um programa de software que lhe permite criar tabelas, calcular e analisar dados. Esse tipo de software é chamado de folha de cálculo. Ele lhe permite criar tabelas que calculam automaticamente os totais de valores numéricos introduzidos, organizar os dados em tabelas de forma atrativa e criar gráficos que facilitam o entendimento dos dados. Ele é considerado uma das melhores plataformas eletrônicas para criação de planilhas.(OFFICE, n.d.)

O Alteryx ${ }^{\circledR}$ por sua vez não é tão conhecido como o Excel®, mas sua funcionalidade é bem similar. O objetivo principal é a análise de dados. A ideia principal do Alteryx $\AA^{\circledR}$ tornar o processo de análise de dados simples, fácil e intuitivo A diferença está principalmente na interface. O Alteryx ${ }^{\circledR}$ trabalha com uma interface intuitiva de "drag-and-drop" para que os usuários criem fluxos de trabalho, na "capacidade" do software. O Alteryx® é mais eficiente ao se tratar de bases mais pesadas, ou seja, com mais dados. E, por fim, o Alteryx $®$ concentra a funcionalidade de vários softwares, na medida em que coleta, trata e mescla informações de diversas fontes, desenvolve e publica modelos analíticos, permitindo ao usuário colocar as informações de forma mais eficiente nas mãos dos responsáveis pela tomada de decisão. Sua licença por ser obtida por estudantes gratuitamente por um ano (ANALYTICS, n.d.)

A plataforma do Alteryx $®$ está representada na Figura 1: 
Figura 1 - Plataforma do programa Alteryx Designer x64

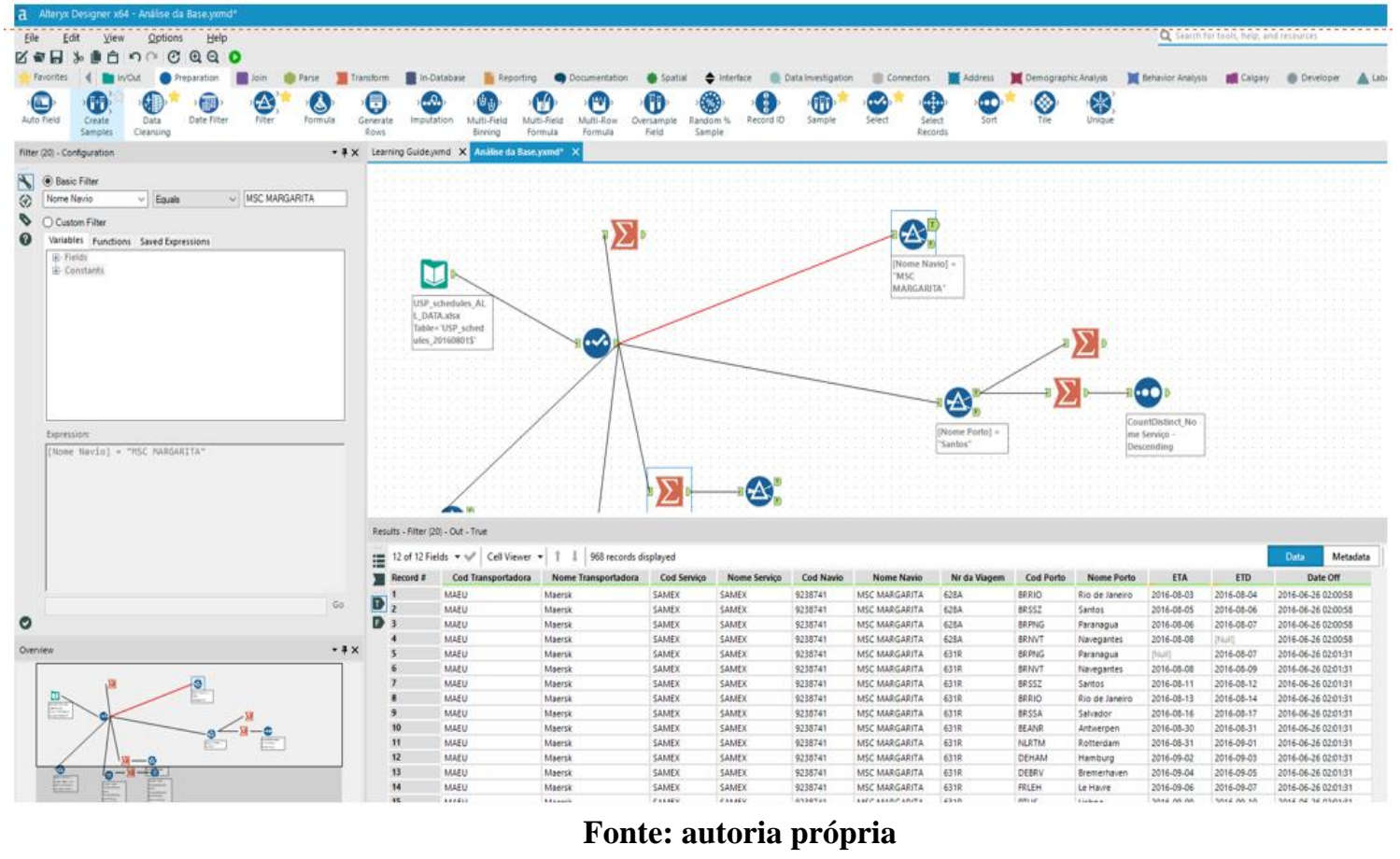

\subsubsection{Sequência de análises realizadas}

Conhecidas as ferramentas utilizadas para análise, deve-se entender qual foi o raciocínio por trás das análises realizadas. A seguir, será apresentado um passo a passo explicando o tratamento dos dados e como foram sendo criadas as tabelas que caracterizaram o tráfego marítimo de contêineres no Brasil.

- $1^{\text {a }}$ etapa: filtrar os portos de interesse, o que fez com que a base se limitasse aos navios que atracaram nos portos brasileiros durante o período de estudo e às suas respectivas rotas;

- $2^{\mathrm{a}}$ etapa: separar os navios pelas características de suas rotas;

- $3^{a}$ etapa: calcular o número de ciclos passando pelo Brasil que cada navio realizou;

- Para os navios recorrentes foi necessário fazer uma limpeza da base manualmente para exclusão dos anúncios de atracação que não foram 
realizados, além da geração de outras estatísticas como tempo de rota no Brasil e no exterior.

- $4^{a}$ etapa: pesquisa a respeito da frota dos navios que passou pelo Brasil (idade dos navios, capacidade, transportadoras, classe); A partir da lista de navios que atracaram nos portos brasileiros, foi possível pesquisar suas características técnicas por meio de ferramentas de busca como livros e sites confiáveis. Muitos sites de portos fornecem gratuitamente informações a respeito dos navios que por ali transitam. Desta forma, pôde-se entender quão nova é a tecnologia que chega ao Brasil, assim como qual o tamanho da oferta brasileira.

- $5^{\text {a }}$ etapa: caracterizar um ano das rotas dos navios não só dentro do Brasil, mas também analisando o destino deles ao redor do mundo;

- $6^{a}$ etapa: gerar análises que apresentam para cada navio a quantidade de viagens distintas que ele anunciou que realizaria em cada um dos portos pelos quais passou, o que pode ser usado para estimar o número de atracações distintas que ele realizou em cada um dos portos pelos quais passou;

- $7^{a}$ etapa: Para garantir que todos os navios que vieram para o Brasil foram contemplados, foi realizada uma análise final de comparação da base da Linescape com uma base de dados que mostrava os navios que passaram pelo Porto de Santos no mesmo ano. Foi escolhido o Porto de Santos por ser o principal porto e por onde passam a maioria dos navios porta-contêineres.

\subsection{Caracterização da oferta do tráfego marítimo de navios porta-contêineres na costa brasileira}

Como dito anteriormente, o objetivo do trabalho é caracterizar o transporte marítimo pela costa brasileira partindo de uma base real de dados. Para isso, fez-se necessário entender, principalmente, as rotas e os navios que compõem o sistema. 
Para descrever a frota de navios foram levantados os seguintes questionamentos: como caracterizar a frota de navios que serve o Brasil? São eles novos ou velhos se comparados com o resto do mundo? Qual a capacidade dos navios da frota?

Por outro lado, para descrever a rota dos navios foram levantados os seguintes questionamentos: existem rotas padrão? Como separar as rotas e quais suas características? Quais rotas os navios realizam no Brasil e para onde eles seguem?

Desta forma, em relação aos navios foi importante conhecer a capacidade, o ano de construção, o tipo do navio e algumas características técnicas dele. Com relação às rotas, foi importante saber quais navios as realizaram, quais os portos principais, quais os portos secundários e com que frequência os navios realizaram essa rota. Com base nesses dois grupos de informações, tornou-se possível estimar a capacidade da oferta de contêineres no Brasil.

É válido observar que a descrição da frota de navios engloba todos os navios. No entanto, a descrição da rota detalhada dos navios foi realizada para uma amostra de 60 navios selecionados, pois vieram de forma mais frequente ao Brasil e apareceram de forma mais representativa na base.

A oferta de contêineres oferecida pelos navios porta-contêineres foi calculada considerando o tipo de navio que serviu cada rota, sua capacidade, ou seja, quanta carga ele é capaz de carregar e a quantidade de vezes que o navio veio para o Brasil em um ano (quantidade de ciclos realizados).

O cálculo da oferta pode ser resumido à seguinte fórmula:

\section{Capacidade do Navio $\times \mathrm{Nr}$ Ciclos (ano)}

Posteriormente esse número será multiplicado por $80 \%$, que é a ocupação máxima real dos navios. Isso é, os navios têm capacidade para carregar um número determinado de contêineres, mas eles ocupam no máximo até $80-85 \%$ da capacidade total por questões de segurança. 
Não é prioridade do trabalho determinar exatamente quantos contêineres de cada navio foram entregues em cada porto. Sabe-se que o navio que chega ao Brasil e traz cargas de portos do exterior (europeus, mediterrâneos, asiáticos) distribui sua carga entre os portos nos quais atraca e a quantidade de contêineres varia conforme a viagem. No entanto, para o cálculo da oferta, foi considerado que a ocupação do navio equivale à sua capacidade (sem discriminar quantos contêineres ficariam em cada porto).

Figura 2 - Exemplo de uma rota de negócios

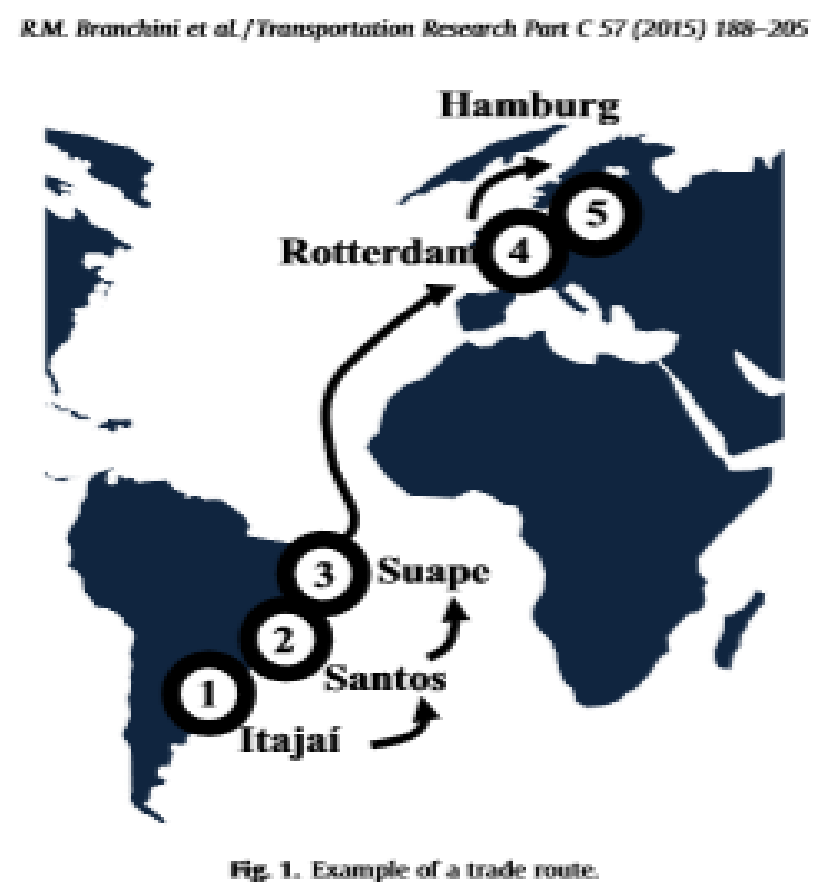

Fonte: R.M Branchini et al./ Transportation Research Part C 57 (2015) 188-205

Como ilustra a imagem, cada vez que o navio vem para o Brasil e atraca nos portos 1, 2 e 3 , é considerado 1 ciclo de viagem e uma oferta equivalente à sua capacidade.

\subsubsection{Descrição da frota de navios que atracou na costa brasileira}

Ao todo, um conjunto de 177 navios foi analisado. No apêndice pode-se ver a Tabela 34 com todos os navios seu ano de construção e sua capacidade. 
A Figura 3 apresenta um histograma com a capacidade nominal em TEUs dos navios.

Figura 3 - Capacidade dos navios porta-contêineres que trafegaram pelo Brasil entre ago/2016 e set/2017 em TEUs

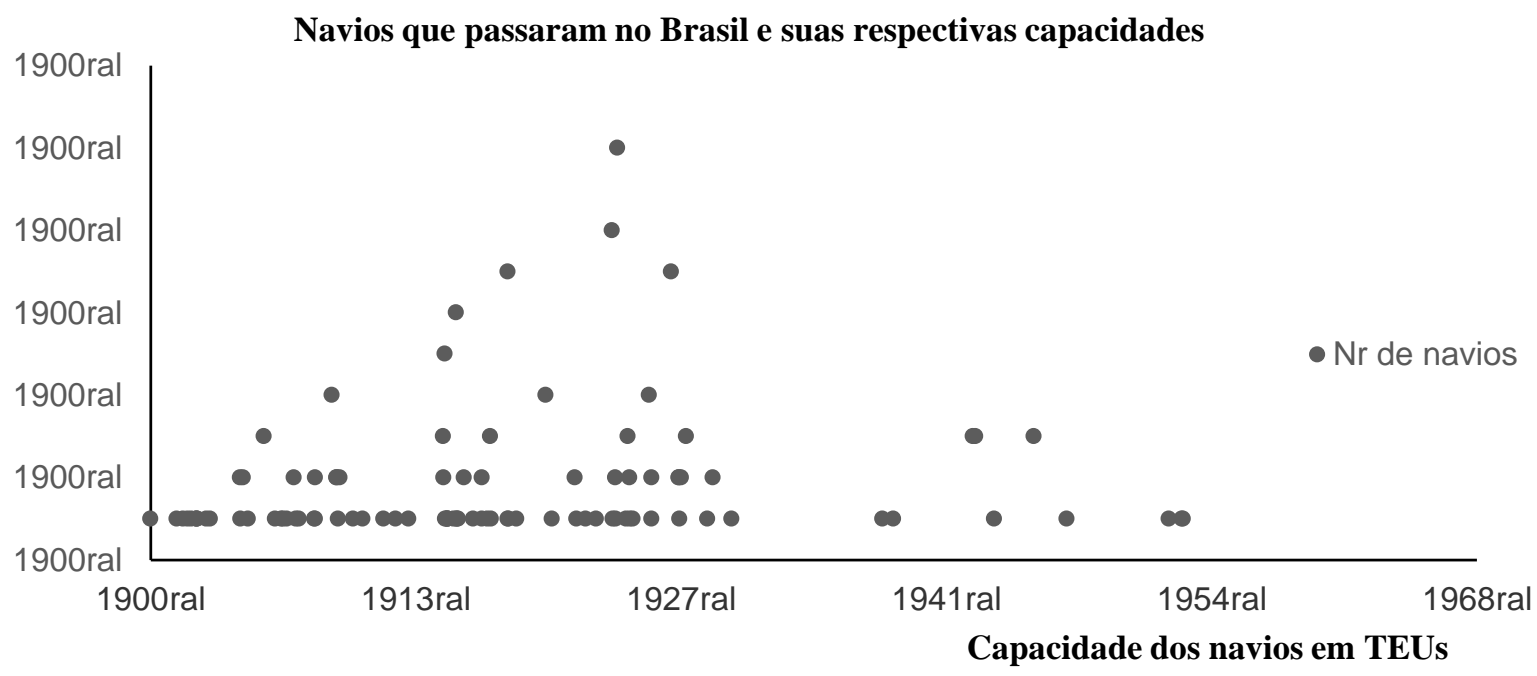

Fonte: autoria própria

A partir do histograma e das tabelas é possível concluir que pequenos navios ainda estão sendo utilizados no Brasil, mas as últimas gerações de navios contêineres estão sendo introduzidos nas rotas. No entanto, vale ressaltar que a maior parte dos navios com capacidade maior que 10.000 TEUs que veio ao Brasil, veio de forma esporádica.

A Figura 4 apresenta um histograma da idade dos navios. Dado que a frota de navios porta-contêineres do mundo tem uma média de idade de aproximadamente 11,5 anos no final de $2017^{48}$, a frota de navios que vem para o Brasil é relativamente nova com seus 8,5 anos de idade média.

48 UNCTAD, Review of Maritime Transport (2017) 
Figura 4 - Ano de construção dos navios porta-contêineres que trafegaram pelo Brasil entre ago/2016 e set/2017 em TEUs

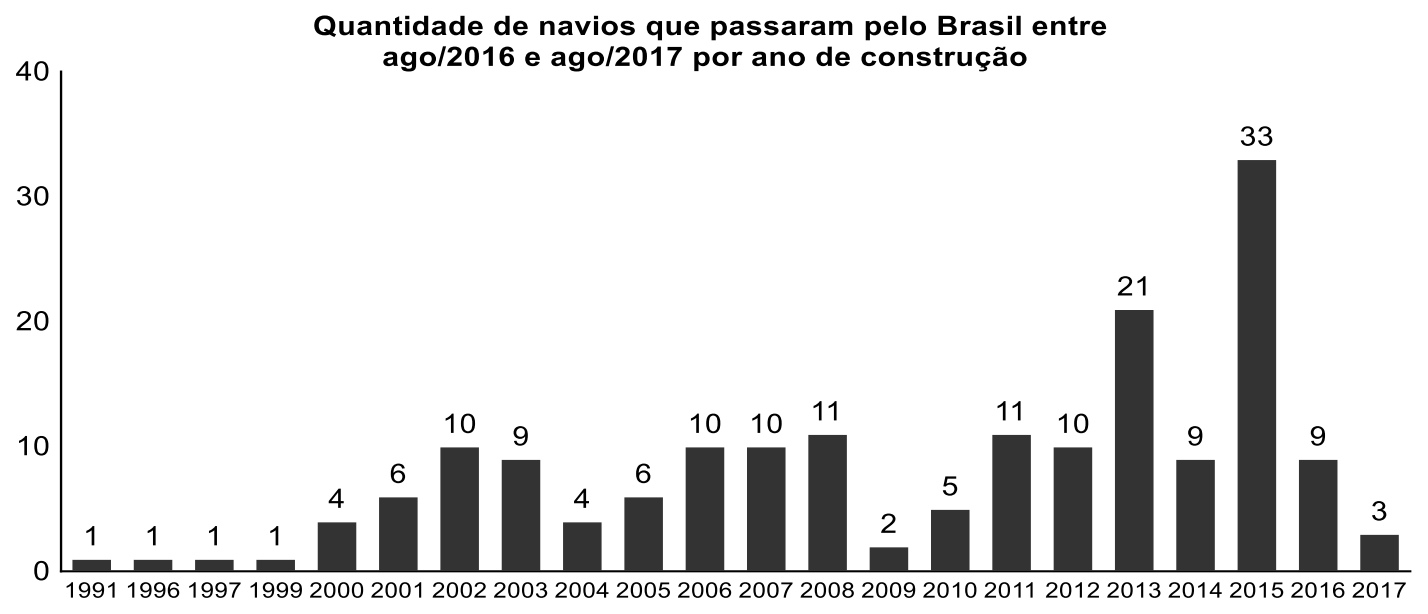

Fonte: autoria própria

Navios como o E.R. London, de 2000, o MSC Ilona, MSC Vidhi e Rio Barrow representam os navios mais antigos da frota com uma capacidade média de 5900 TEUs, enquanto os mais novos são o Cap San Antonio, Cap San Artemissio, Cap San Maleas, Cap San Raphael e MSC Azov com uma capacidade média de 9868 TEUs.

A seguir uma comparação entre a capacidade da frota e a idade dos navios: 
Figura 5 - Comparação entre a capacidade dos navios (em TEUs) e o ano de construção dos mesmos

Evolução da capacidade dos navios que passaram pelo Brasil

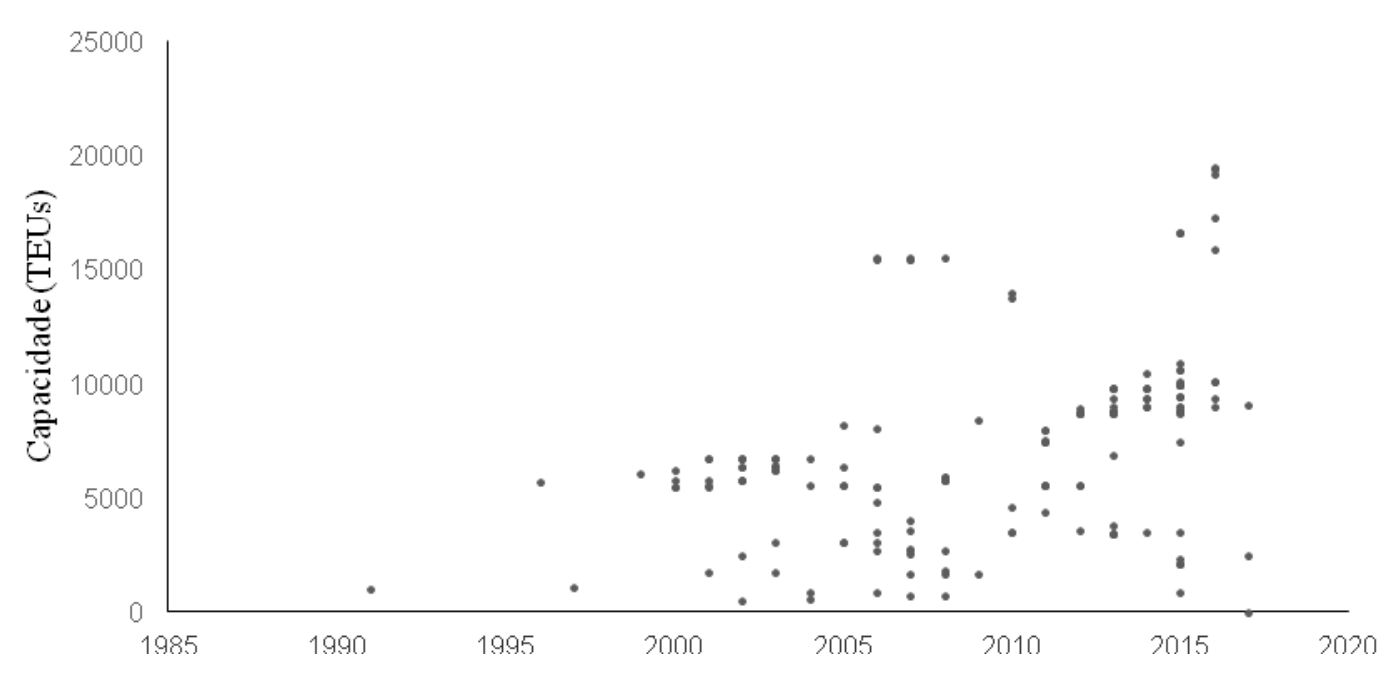

Fonte: autoria própria

Desta forma, pode-se concluir que a capacidade dos navios está aumentando, já que os navios estão sendo construídos cada vez maiores.

Os portos pelos quais cada um dos navios atracou em suas rotas estão apresentados no apêndice $\mathrm{C}$ através de tabelas que mostram os navios, os portos e o número de viagens que cada navio anunciou que realizaria em cada porto.

\subsubsection{Descrição das rotas dos navios}

\subsubsection{Contextualização dos portos brasileiros e identificação das rotas padrão}

Inicialmente apresentaremos uma contextualização dos portos brasileiros e posteriormente, as rotas padrões identificadas com a análise da base. 
Para facilitar a visualização das rotas, a Figura 2 apresenta os principais portos brasileiros em um mapa.

Figura 6 - Localização dos principais portos brasileiros

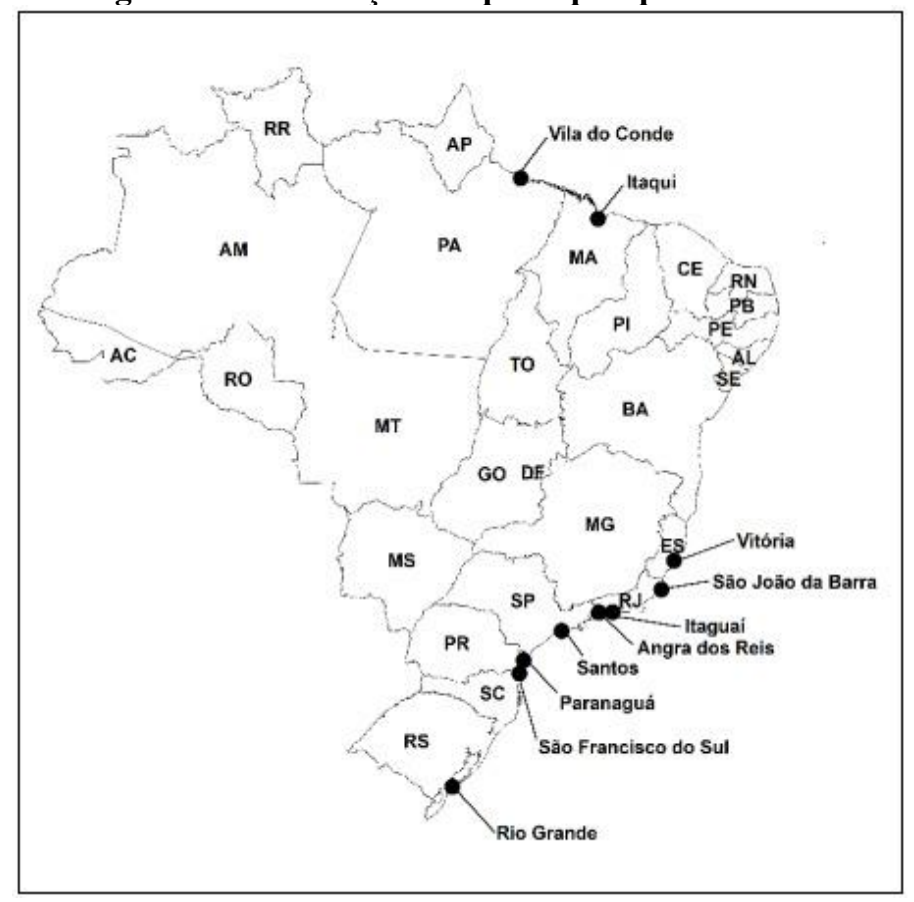

Fonte: (ANTAQ, 2018)

As análises na base de dados foram feitas filtrando os principais portos ${ }^{49}$ brasileiros movimentadores de contêineres: Santos (SP), Paranaguá (PR), Rio Grande (RS), Itapoá (SC), Rio de Janeiro (RJ), Navegantes(SC), Salvador (BA), Itajaí (SC), Suape (PE), Vitória (ES), Fortaleza (CE), Natal (RN), Pecém (CE) e Vila do Conde (PA).

Decidiu-se incluir também nas análises, dois portos bem relevantes da América do Sul: Buenos Aires e Montevidéu. Esses portos são respectivamente o $9^{\circ}$ e o $17^{\circ}$ portos no ranking dos 20 principais na América Latina e no Caribe em 2016, com 1.352.068 e 888.119 TEUs movimentados segundo (CEPAL, 2017) ${ }^{50}$.

\footnotetext{
${ }^{49}$ Com relação à nomenclatura da base que foi utilizada para descrever as rotas da dissertação, deve-se atentar ao fato de que as movimentações do porto de Itaguaí (RJ) estão dentro dos portos chamados "Rio de Janeiro" e as de São Francisco do Sul (SC) estão contidas nas movimentações de Itapoá ou Itajaí.

${ }^{50}$ CEPAL - Comissão Econômica para América Latina e Caribe
} 
A análise das rotas foi feita a partir da identificação e agrupamento das rotas padrão que alguns navios realizaram. Filtrando para cada navio, os portos nos quais eles atracaram (dentre os portos selecionados) e a frequência de atracação, foi possível identificar um total de seis principais rotas padrão que serão apresentadas na Tabela 5:

Tabela 3 - Portos que compõem cada rota

\begin{tabular}{llllll}
\hline Rota A & Rota B & Rota C & Rota D & Rota E & Rota F \\
\hline Buenos Aires & Paranagua & Itajai & Buenos Aires & Santos & Fortaleza \\
\hline Itaguai & Rio de Janeiro & Itapoa & Itajai & Vitoria & Natal \\
\hline Itajai & Salvador & Paranagua & Itapoa & Rio de Janeiro & Vila do Conde \\
\hline Itapoa & Santos & Salvador & Montevideo & \\
\hline Montevideo & Navegantes & Santos & Paranagua & \\
\hline Paranagua & & Rio Grande & \\
\hline Pecem & & Rio de Janeiro \\
\hline Rio Grande & & Salvador \\
\hline Santos & & Santos \\
\hline \multicolumn{5}{c}{ Suape } \\
\hline
\end{tabular}

Fonte: autoria própria

Pode-se perceber que algumas rotas, como as rotas B e D, passam pelos mesmos portos inicialmente, mas a rota $\mathrm{D}$ continua por outros portos.

Nem todos os navios fizeram uma dessas rotas, mas a identificação de rotas padrões pelas quais passaram grande parte dos navios, foi necessário para direcionar a pesquisa. Dos 177 navios estudados inicialmente, 96 tiveram suas rotas apresentadas no estudo e 60 tiveram suas rotas estudadas no detalhe.

Os 96 navios foram separados em dois grupos, como será apresentado a seguir.

\subsection{Separação dos navios em dois grupos: recorrentes e "spot" com base na frequência que os navios atracaram nos portos}

Os navios foram divididos conforme a frequência que eles atracaram nos portos brasileiros. Os navios que anunciaram que atracaram até três vezes nos portos brasileiros, foram considerados "spots", ou seja, esporádicos. E os navios que anunciaram que atracaram mais de 
três vezes nos portos brasileiros foram considerados navios recorrentes e agrupados em uma das rotas identificadas.

Abaixo segue uma lista dos navios considerados "spots" e as rotas que eles percorreram:

Tabela 4 - Dentre os navios escolhidos, lista de navios spots que passaram pelo Brasil

\begin{tabular}{llll}
\hline Nome do Navio & Nome do Navio & Nome do Navio & Nome do Navio \\
\hline Dali & Msc Emanuela & Msc Kalamata & Maersk Saltoro \\
\hline Elly Maersk & Msc Gaia & Msc Kolkata & Maersk Shams \\
\hline Emma Maersk & Msc Hamburg & Msc Anna & Maersk Stadelhorn \\
\hline Estelle Maersk & Msc Soraya & Widukind & Msc Amsterdam \\
\hline Maersk Genoa & Msc Venice & Msc Margarita & Msc Eloane \\
\hline Maersk Gibraltar & Maersk Kobe & Durande & Msc Erica \\
\hline Maersk Guayaquil & Msc Geneva & Ebba Maersk & Msc Istanbul \\
\hline Maersk Sarat & Msc Ilona & Eleonora Maersk & Msc Mirjam \\
\hline Msc Carolina & Msc Judith & Eugen Maersk & Msc Kingston \\
\hline
\end{tabular}

Fonte: autoria própria

E uma lista dos navios recorrentes, separados pela rota que percorreram.

Tabela 5 - Navios que compõe cada rota

\begin{tabular}{llllll}
\hline Rota 1 & Rota 2 & Rota 3 & Rota 4 & Rota 5 & Rota 6 \\
\hline Cap San Antonio & E. R. London & Bf Caroda & Msc Alicante & Amazonia & Cma Cgm Brazil \\
\hline $\begin{array}{llll}\text { Cap San } \\
\text { Artemissio }\end{array}$ & Mol Genesis & Helga & $\begin{array}{l}\text { Msc } \\
\text { Barcelona }\end{array}$ & Pantanal & Cma Cgm Cayenne \\
\hline Cap San Augustin & Msc Barbara & Msc Julie & Msc Cadiz & Cma Cgm Marseille \\
\hline Cap San Lorenzo & Msc Fiammetta & Msc Meline & Msc Coruna & Cma Cgm Saint \\
\hline Cap San Maleas & Msc Katyayni & Wms Harlingen & Msc Madrid & Marfret Guyane \\
\hline Cap San Marco & Msc Krystal & X-Press & Msc Marta & Marfret Marajo \\
\hline Cap San Nicolas & Msc Marianna & Msc Agadir & Msc Vigo & \\
\hline Cap San Raphael & Msc Marina & Msc Ajaccio & Rhodos & \\
\hline Cezanne & Msc Oriane & Msc Amalfi & Rio De Janeiro & \\
\hline Maersk Laberinto & Msc Vidhi & Msc Arica & Rio Negro & & \\
\hline Maersk Labrea & Northern Majestic & Msc Azov & & \\
\hline Maersk Lamanai & Rio Barrow & Msc Letizia & & \\
\hline Maersk Lanco & Max Loyalty & & & \\
\hline Maersk Leon & & & & \\
\hline Maersk Lima & & & & \\
\hline Maersk Lins & & & \\
\hline Maersk Lota & & & \\
\hline Fonte: autoria propace & & \\
\hline
\end{tabular}

Fonte: autoria própria 
Como dito anteriormente, foi realizada uma limpeza na base considerando TEC, TEP e a data do último anúncio para identificar quantas vezes de fato os navios atracaram nos portos e quantas vezes eles anunciaram que atracariam, mas atrasaram e tiveram que anunciar uma nova data para atracação.

Com isso foi determinado o número de vezes que o navio realizou uma rota na costa brasileira, ou seja, o número de ciclos durante esse ano analisado. Com essa mesma base tratada manualmente foi possível determinar quanto tempo durou em média a rota do navio no Brasil e no exterior verificando a quantidade de dias entre a atracação no primeiro porto brasileiro da rota e no último.

Para entender melhor a frequência do navio na rota, foi analisado quanto tempo cada navio opera na rota. O tempo médio de todos os navios recorrentes em rota no Brasil é de 15,1 dias e o tempo médio de rota no exterior é de 21,1 dias. Os resultados são encontrados no apêndice B, tabela 35 .

Deve-se ressaltar que nem todos os navios passaram o ano todo na mesma rota e esse tempo médio é muito relativo, pois as rotas são muito diferentes entre si.

\subsubsection{Particularidades de cada uma das rotas}

Para cada uma das rotas foram identificados: os portos e navios pertencentes às rotas, as características dos seus respectivos navios e algumas estatísticas das rotas - tais como o tempo médio dos navios em viagem no Brasil - a quantidade de vezes aproximada de atracação dos navios nos portos, com base no número de viagens anunciadas por porto, um exemplo da rota de um ou mais navios e o cálculo da oferta dos navios para essa rota durante um ano.

\subsection{Rota A}

A primeira rota a ser descrita é a rota cujos navios passam com frequência pelos portos de Santos, Paranaguá, Rio Grande, Itapoá, além dos portos sul-americanos de Buenos Aires e Montevidéu e esporadicamente pelos portos de Itaguaí, Itajaí e Pecém. 
A sequência da rota é geralmente a sequência Santos, Paranaguá, Buenos Aires, Montevidéu, Rio Grande e Itapoá.

Na maioria das vezes na volta o navio retorna para Santos antes de seguir para o exterior e algumas vezes ele passa também por Paranaguá nesse trajeto de volta.

A rota de quase todos os navios no exterior é o norte da Europa, que consiste principalmente nos portos de Roterdã, Londres, Hamburgo, Antuérpia, Le Havre e Bremerhaven.

O fato de os navios não passarem cem por cento das vezes pelo mesmo porto vai contra a descrição dos serviços de linhas regulares que determina que as rotas sejam fixas.

Para entender melhor as características desta rota, deve-se estudar mais afundo o trajeto dos navios individualmente. Desta forma, é possível entender se todos realizam o mesmo trajeto durante o ano todo, com o mesmo tempo de rota, vão para o mesmo destino, entre outras coisas.

Mais adiante no texto serão apresentadas duas tabelas. A primeira (Tabela 8) com as características dos navios: ano de construção e capacidade em TEUs. A segunda (Tabela 34) indica a quantidade de vezes que os navios passaram pelos portos. Vale ressaltar que esses números provavelmente não são exatos, no entanto, a base nos dá uma ideia da quantidade de vezes que os navios passaram nos portos.

Os navios dessa rota podem ser separados em três tipos:

- Classe CAP: Cap San Antonio, Cap San Artemissio, Cap San Augustin, Cap San Lorenzo, Cap San Maleas, Cap San Marco, Cap San Nicolas, Cap San Raphael.

- Navios Maersk: Maersk Laberinto, Maersk Labrea, Maersk Lamanai, Maersk Lanco, Maersk Leon, Maersk Lima, Maersk Lins, Maersk Lota

- Outros: Cezanne 
Tabela 6 - Características e estatísticas dos navios da rota 1

\begin{tabular}{lll}
\hline Nome Navio & Ano & TEUs \\
\hline Cap San Antonio & 2014 & 9814 \\
\hline Cap San Artemissio & 2014 & 9814 \\
\hline Cap San Augustin & 2013 & 9814 \\
\hline Cap San Lorenzo & 2013 & 9814 \\
\hline Cap San Maleas & 2014 & 10500 \\
\hline Cap San Marco & 2013 & 9814 \\
\hline Cap San Nicolas & 2013 & 9814 \\
\hline Cap San Raphael & 2014 & 9814 \\
\hline Cezanne & 2015 & 9971 \\
\hline Maersk Laberinto & 2012 & 8700 \\
\hline Maersk Labrea & 2013 & 8700 \\
\hline Maersk Lamanai & 2013 & 8700 \\
\hline Maersk Lanco & 2013 & 8700 \\
\hline Maersk Leon & 2012 & 8700 \\
\hline Maersk Lima & 2011 & 7564 \\
\hline Maersk Lins & 2012 & 8700 \\
\hline Maersk Lota & 2012 & 8700 \\
\hline
\end{tabular}

Fonte: autoria própria

O primeiro grupo de navios realiza um número médio de 10,1 viagens com tempo de rota no Brasil de 19,1 dias e 14,4 dias no exterior. O segundo tem um tempo médio de viagem um pouco mais alto, o que lhes impede de fazer tantas viagens durante o ano. O tempo médio em rota no Brasil é de 27,4 dias e no exterior de 24,9 dias. Esses navios fazem em média 6,3 viagens por ano.

O navio Cezanne não se enquadra em nenhum dos grupos, além disso, como veremos mais adiante, apesar de realizar uma rota similar à dos outros navios, ele passa por muitos outros portos, o que indica que ele provavelmente tem mais de uma rota para realizar durante o ano.

No apêndice está apresentada a Tabela 30 (dividida em duas partes), com a quantidade de viagens distintas que os navios anunciaram por porto.

Como podemos ver com a Tabela 30, a rota dos navios da classe Cap da Hamburg Süd é bem consistente. Os navios passaram uma quantidade de vezes similar pelos mesmos portos tanto internacionais quanto brasileiros. Alguns portos como Algeciras, Bremerhaven, Itajaí, 
Pecém, Tanger Med, Tanjung e Tilbury não são portos constantes da rota, como é possível perceber pela quantidade de vezes que os navios passaram por esses portos.

O navio Cézanne, além dos portos normais da rota, passou muitas vezes por portos fora da rota no Oriente Médio, Norte da África e Europa. Após analisar melhor a base, foi possível constatar que durante o ano de 2016, esse navio realizava uma rota diferente composta pelos portos: Salalah, Jeddah, As Suways, Tangier, Felixstowe, Antwerpen, Bremerhaven, Wilhelmshaven, Rotterdam, Algeciras, 'Aqaba, Jebel Ali, Nhava Sheva, Mundra, Tanjung Priok e Genova. A partir de 2017, no entanto, ele começou a realizar a rota que realizam os outros navios classificados nesta rota.

Os navios da Maersk se diferenciam um pouco dos navios Cap não apenas pela quantidade de vezes que passaram nos portos, mas também por quais portos eles passaram. Por exemplo, os navios da Maersk passaram menos vezes pelos portos de Itaguaí e Itapoá, até mesmo Buenos Aires e Montevidéu.

Para entender melhor o funcionamento dessa rota, deve-se acompanhar ao menos um dos navios pelo seu trajeto durante o ano todo. No caso da Rota A, foi apresentada a descrição da rota do Cap San Antonio, o trajeto que o navio Cap San Antonio realizou durante os anos de 2016 e 2017 está no apêndice D.

Pode-se observar que o navio realizou oito ciclos da rota (Londres, Hamburgo, Antuérpia, Le Havre, Santos, Paranaguá, Buenos Aires, Montevidéu, Rio Grande, Itapoá, Paranaguá, Santos, Tanger Med e Roterdã), sendo que a média de tempo do navio na rota foi de 37,2 dias:

Para calcular a oferta da rota A, foi considerada a capacidade média dos navios de cada grupo de embarcações e ela foi multiplicada pelo número médio de viagens do mesmo, como ilustra a fórmula abaixo:

\section{Capacidade do Navio $\times \mathrm{Nr}$ Ciclos (ano)}


Tabela 7 - Cálculo da oferta da rota A

\begin{tabular}{llll}
\hline Nome do navio & Capacidade (TEUs) & \# de navios & Viagens por ano \\
Grupo Cap & 9899,75 & 8 & 10,4 \\
Grupo Maersk & 8700 & 8 & 6,6 \\
Cezanne & 9971 & 1 & 4 \\
\hline
\end{tabular}

Fonte: autoria própria

\subsection{Rota B}

$\mathrm{Na}$ rota $\mathrm{B}$, os navios atracaram constantemente nos portos do Rio de Janeiro, Santos, Paranaguá, Navegantes e Salvador.

A sequência dos portos pelos quais os navios atracam é geralmente os portos de Rio de Janeiro, Santos, Paranaguá, Navegantes, Rio de Janeiro novamente e Salvador. A rota da maioria desses navios no exterior é Roterdã, Hamburgo, Bremerhaven, Le Havre, Sines, Lisboa e Antuérpia. Alguns dos navios passaram também algumas vezes por Valência.

Os navios que compõem essa rota podem ser separados em 2 grandes grupos:

- Navios MSC: Msc Barbara, Msc Fiammetta, Msc Katyayni, Msc Krystal, Msc Marianna, Msc Marina, Msc Oriane, Msc Vidhi.

- Outros: E.R. London, Mol Genesis, Northern Majestic e Rio Barrow.

A seguir a Tabela 10 com características de cada navio:

Tabela 8 - Características e estatísticas dos navios da rota 2

\begin{tabular}{lll}
\hline Nome Navio & Ano & TEUs \\
\hline E.R. London & 2000 & 5762 \\
\hline MOL GENESIS & 2012 & 5605 \\
\hline MSC BARBARA & 2002 & 6402 \\
\hline MSC FIAMMETTA & 2008 & 5770 \\
\hline MSC KATYAYNI & 1996 & 5771 \\
\hline MSC KRYSTAL & 2008 & 5762 \\
\hline MSC MARIANNA & 2002 & 6730 \\
\hline MSC MARINA & 2003 & 6402 \\
\hline MSC ORIANE & 2008 & 5782 \\
\hline MSC VIDHI & 2001 & 5514 \\
\hline NORTHERN MAJESTIC & 2004 & 6750 \\
\hline RIO BARROW & 2001 & 5551 \\
\hline
\end{tabular}

Fonte: autoria própria 
Os navios têm tempo médio de viagem de 36,6 dias, sendo 12,6 em rota dentro do Brasil e 24,9 em rota fora do Brasil. O número de viagens médio desse grande grupo de navios é de 6,5 viagens.

Os tempos em rota dos navios no Brasil estão bem similares, o que pode ser ocasionado, entre outras coisas, pelo fato de os portos desta rota estarem próximos entre si, o que pode diminuir os atrasos dos navios em tempos de rota.

No apêndice $\mathrm{C}$ temos a quantidade de viagens distintas que os navios anunciaram por porto.

Como podemos ver pela Tabela 38, os navios da MSC realizam rotas muito similares. Algumas exceções como o MSC Krystal, o MSC Marianna, MSC Katyayni e o MSC Vidhi saem da rota algumas vezes, mas em geral os navios atracam sempre nos mesmos portos.

Os números da Tabela 38 estão altos, mas como dito anteriormente não indicam exatamente a quantidade de atracações dos navios nos portos, e sim, o número de viagens realizadas por navio no porto. No entanto, podemos perceber, por exemplo, que os portos do Rio de Janeiro, Salvador, Santos, Sines, Hamburg e Lisboa para alguns navios não fazem parte da rota principal, são apenas portos secundários.

Para o estudo individual dos navios foram analisados dois navios: o MSC Fiammetta e o MSC Krystal. No entanto, grande parte do ano o MSC Fiammetta realiza uma pequena rota na Europa, o que não está dentro do foco de estudo que seria a caracterização da rota marítima brasileira. Essa discrepância pode ser identificada na Tabela 38 que indica que o MSC Fiammetta atracou 25 vezes na Antuérpia e apenas sete em Salvador. Desta forma, para o cálculo da oferta serão considerados principalmente os dados do MSC Krystal.

Os navios desse segundo grupo não seguem um padrão muito consistente. O E.R. London e o Mol Gênesis, por exemplo, passaram algumas vezes por rotas nos Estados Unidos e algumas vezes por portos na Arábia ou na Austrália. Os outros dois se mantiveram sempre na mesma rota similar à dos portos da MSC.

No apêndice A temos os exemplos dos navios estudados. 
Ao analisar a rota de cada um dos navios separadamente, é possível identificar que não são todos os navios que realizam essa mesma rota durante o ano todo.

O MSC Fiammetta e o MSC Vidhi ficaram grande parte do tempo realizando rotas que não passavam pelo Brasil. O MSC Vidhi estava percorrendo o Oriente médio, assim como o Mediterrâneo e o norte da Europa. O MSC Fiammeta, por sua vez, ficou alguns meses realizando pequenos ciclos pela Europa. A Tabela 38 destaca a quantidade de vezes que o navio passou pelo porto de Hamburgo para ressaltar que os ciclos eram curtos e contemplavam sempre os mesmos portos apesar de estarem em ordens diferentes.

O MSC Fiammetta nos mostra como os navios nem sempre percorrem a mesma rota e mesmo que passando pelos mesmos portos repetidamente, por vezes, alteram a ordem de atracação. Isso ocorre devido à demanda esporádica de cada porto e comprova que com o objetivo de aperfeiçoar suas rotas e potencializar seus lucros, os navios não mais percorrem rotas fixas e pré-determinadas e sim, reprogramam e definem seus horários com base na demanda que eles recebem.

O MSC Krystal é um exemplo de um navio cuja rota é bem constante. Ele passa muitas vezes pelos mesmos portos, na mesma sequência e demora tempos similares para realizar os mesmos percursos. Por causa disso, ele será utilizado para calcular a oferta.

Para calcular a oferta da rota 2, os navios foram separados em 3 grupos:

- Navios com rota normal: MSC Krystal, E.R. London, MOL Genesis, MSC Katyayni, MSC Marianna, MSC Oriane, Northern Majestic, Rio Barrow

- Navios que não passam o tempo todo na rota que passa pelo Brasil: MSC Fiammetta, MSC Bárbara, MSC Marina,

\section{- Exceções: MSC Vidhi}

Os navios com rota normal seguirão os padrões do MSC Krystal, sete viagens durante o ano todo. 
Os navios que não passam o tempo todo em rota que passa pelo Brasil seguem os padrões do MSC Fiammetta, que fez três viagens no ano todo. Esses navios foram identificados pela proporção entre a quantidade de vezes que passaram em outros portos e vezes que passaram nos portos brasileiros.

Para as exceções, consideraremos apenas o MSC Vidhi e pela análise da sua rota, entendemos que ele fez metade do tempo em rota passando pelo Brasil, portanto, das treze viagens, seis serão consideradas no cálculo da oferta.

Assim como para todos os cálculos de oferta será considerada a capacidade média de cada grupo de navios e ela será multiplicada pelo número médio de viagens do mesmo (levandose em consideração as viagens nas quais os navios não passaram pelo Brasil).

Tabela 9 - Cálculo da oferta da rota B

\begin{tabular}{llll}
\hline Grupo de navios & Capacidade (TEUs) & \# de navios & Viagens por ano \\
Grupo 1 & 5762 & 8 & 7 \\
Grupo 2 & 5770 & 3 & 3 \\
Grupo 3 & 5514 & 1 & 6 \\
\hline
\end{tabular}

Fonte: autoria própria

\subsection{Rota C}

A terceira rota descrita contém navios que atracaram constantemente nos portos de Itajaí, Itapoá, Paranaguá, Salvador e Santos. A sequência dos portos é geralmente a seguinte: Itajaí, Itapoá, Paranaguá, Salvador e Santos. A maioria desses navios realiza uma rota similar fora do Brasil também, passando por Algeciras, Valencia, Tanjung Priok e Las Palmas de Gran Canaria

Os navios que compõem essa rota foram separados em dois grandes grupos:

- Grupo MSC: MSC Julie, MSC Meline, MSC Agadir, Msc Ajaccio, MSC Amalfi, MSC Arica, MSC Azov e MSC Letizia

- Outros: BF Caroda, Helga, Wms Harlingen, X-Press Mullhacen e Max Loyalty

A seguir, a Tabela 12 com as estatísticas e características de cada navio: 
Tabela 10 - Características e estatísticas dos navios da rota $\mathbf{C}$

\begin{tabular}{lll}
\hline Nome Navio & Ano & TEUS \\
\hline BF CARODA & 2004 & 862 \\
\hline HELGA & 2008 & 1700 \\
\hline XMS HARLINGEN & 2007 & 698 \\
\hline MAX LOYALTY & 2008 & 767 \\
\hline MSC JULIE & 2006 & 868 \\
\hline MSC MELINE & 2015 & 8800 \\
\hline MSC AGADIR & 2015 & 8800 \\
\hline MSC AJACCIO & 2012 & 8900 \\
\hline MSC AMALFI & 2014 & 9400 \\
\hline MSC ARICA & 2012 & 8700 \\
\hline MSC AZOV & 2014 & 9400 \\
\hline MSC LETIZIA & 2015 & 8800 \\
\hline
\end{tabular}

Fonte: autoria própria

O grupo dos MSC tem tempo médio de rota no Brasil de 8,8 dias e um tempo médio de rota fora do Brasil de 26,5 dias. Os outros navios, por sua vez, têm um tempo de rota no Brasil similar de 9,3 dias. O número de médio de viagens dos navios MSC é de 6,6 viagens. O número médio dos outros navios é de 13.

No apêndice $\mathrm{C}$ temos a quantidade de viagens distintas que cada navio anunciou por porto.

No que diz respeito aos navios da MSC, podemos ver que todos seguem um padrão com relação à frequência nos portos indicados como principais nesta rota. Além disso, eles seguem as rotas com maior rigidez do que os outros navios que têm rotas bem diferentes ao longo do ano. Alguns navios como o MSC Arica, o MSC Julie e o MSC Letizia, realizam outras rotas fora do Brasil, passando por um número maior ou diferente de portos. Os outros navios, entretanto, não têm uma rota fixa que possa ser caracterizada.

Para entender melhor a rota desses navios, pode-se analisar um trecho do trajeto percorrido pelo navio MSC Azov que foi apresentada no apêndice C.

Para calcular a oferta da rota três, os navios foram separados nos grupos prédeterminados anteriormente. 
Os navios da MSC são em geral mais novos e tem uma capacidade média mais alta, por volta de 9000 TEUs. Os navios classificados como outros têm uma capacidade menor, portanto, uma aproximação desses números não teria tanto impacto no cálculo da oferta final.

Assim como para todos os cálculos de oferta será considerada a capacidade média de cada grupo de navios e ela será multiplicada pelo número médio de viagens do mesmo.

\begin{tabular}{|llll|}
\hline \multicolumn{2}{l}{ Tabela 11 - Cálculo da oferta da rota C } & & \\
\hline Grupo de navios & Capacidade media (TEUs) & \# de navios & Viagens por ano \\
\hline Grupo 1 & 9000 & 8 & 7 \\
Grupo 2 & 700 & 5 & 3 \\
\hline
\end{tabular}

Fonte: autoria própria

\subsection{Rota D}

Os navios foram agrupados conjuntamente, pois todos realizam com certa frequência a seguinte rota na América do Sul: Buenos Aires, Itajaí, Itapoá, Montevidéu, Paranaguá, Rio Grande, Rio de Janeiro, Salvador, Santos e Suape.

Esta é uma das maiores rotas realizadas pelos navios no Brasil, ou pelo menos a rota que passa por um maior número de portos.

A maioria desses navios realiza uma rota similar fora do Brasil também, passando por Valência, Gioria Tauro, Livorno, Genova, Fos sur Mer e Barcelona. Atracando também algumas vezes em Tanger Med e Tangier,

Os navios desta rota não serão agrupados em subgrupos, pois todos têm características de idade e capacidade similares. A média de idade dos navios é de aproximadamente oito anos e a capacidade média deles é de 5644 TEUs.

Seguindo o padrão de descrição das outras rotas, tem-se a seguir a Tabela 14 com as características dos navios que pertencem a essa rota. 
Tabela 12 - Características e estatísticas dos navios da rota D

\begin{tabular}{lll}
\hline Nome Navio & Ano & TEUs \\
\hline MSC ALICANTE & 2011 & 5550 \\
\hline MSC BARCELONA & 2011 & 5550 \\
\hline MSC CADIZ & 2011 & 4390 \\
\hline MSC CORUNA & 2011 & 5550 \\
\hline MSC MADRID & 2011 & 5550 \\
\hline MSC MARTA & 2005 & 5599 \\
\hline MSC VIGO & 2012 & 5550 \\
\hline RHODOS & 2013 & 6900 \\
\hline RIO DE JANEIRO & 2008 & 5905 \\
\hline RIO NEGRO & 2008 & 5905 \\
\hline
\end{tabular}

Fonte: autoria própria

Esses navios têm um tempo médio de rota no Brasil de 21,5 dias e um tempo médio de rota no exterior de 17,6 dias.

O número médio de viagens é de 8,3 viagens por ano, um número alto se comparado com as outras rotas, com exceção de quatro navios: o MSC Madrid, o MSC Marta, o MSC Vigo e o Rhodos, que muitas vezes passaram por portos além dos portos normais da rota e algumas vezes (uma ou duas vezes) atracaram em alguns portos pontuais como em Altamira, Algeciras, Balboa, Colombo, Cristobal, entre outros, que os fez ter rotas mais longas e um número menor de viagens.

Para analisar o trajeto desses navios foram selecionados dois exemplos: o navio Rio de Janeiro e o navio MSC Madrid.

A quantidade de viagens distintas que cada navio anunciou que faria por porto além do trajeto dos navios Rio de Janeiro e MSC Madrid foi descrita no apêndice.

Para calcular a oferta para a rota $\mathrm{D}$, basta multiplicar a capacidade média dos navios pelo número de viagens realizadas.

Tabela 13 - Cálculo da oferta da rota $D$

\begin{tabular}{|llll}
\hline Grupo de navios & Capacidade (TEUs) & \# de navios & Viagens por ano \\
Grupo 1 & 5644 & 10 & 8,3 \\
\hline Fonte: autoria própria & &
\end{tabular}




\subsection{Rota $E$}

A rota E, por sua vez, é uma rota menor composta apenas por dois navios, Pantanal e Amazônia. Esses dois navios passam pelos portos de Rio de Janeiro, Santos e Vitória.

A seguir, a Tabela 16 com as características dos navios.

Tabela 14 - Características e estatísticas dos navios da rota $\mathbf{E}$

\begin{tabular}{lll}
\hline Nome Navio & Ano & TEUs \\
\hline AMAZONIA & 1991 & 1050 \\
\hline PANTANAL & 2004 & 611 \\
\hline
\end{tabular}

Fonte: autoria própria

O tempo médio em rota dentro do Brasil é de cinco dias e o tempo que o navio leva para retornar ao primeiro porto e começar novamente a rota é de três dias. O número de viagens que esses navios realizam durante o ano é mais alto, como indica a Tabela 17. São em média 27 viagens por ano.

Tabela 15 - Quantidade de vezes que os navios da rota 5 anunciaram que atracariam nos portos

\begin{tabular}{lll} 
Navios/ Portos & Pantanal & Amazonas \\
Rio & $25 \mathrm{x}$ & $30 \mathrm{x}$ \\
Santos & $25 \mathrm{x}$ & $30 \mathrm{x}$ \\
Vitoria & $24 \mathrm{x}$ & $30 \mathrm{x}$ \\
\hline
\end{tabular}

Fonte: autoria própria

O entendimento dessa rota é simples dado o número de navios que a compõem e o trajeto dos mesmos. Pelas características da rota esses são navios de cabotagem. No apêndice, tem-se a descrição da rota de um dos navios.

Para calcular a oferta para a rota cinco, basta multiplicar a capacidade dos navios pelo número de viagens realizadas. No entanto, por serem considerados navios de cabotagem não serão incluídos no nosso cálculo de oferta final de navios de longo curso.

Tabela 16 - Cálculo da oferta da rota $\mathrm{E}$

\begin{tabular}{|llll}
\hline Nome do navio & Capacidade média (TEUs) & \# de navios & Viagens por ano \\
Amazonia & 1050 & 1 & 24 \\
Pantanal & 611 & 1 & 30 \\
\hline
\end{tabular}

Fonte: autoria própria 


\subsection{Rota F}

A última rota, denominada rota $\mathrm{F}$, é composta por navios que realizam grandes rotas no exterior, mas passam apenas pelos portos de Natal e Fortaleza no Brasil.

Após atracarem nesses portos brasileiros, os navios seguem para as rotas europeias, atracando em Algeciras, Antuérpia, Degrad des Cannes, Vila do Conde, Fort de France, Le Havre, Leixões, Porto da Espanha, Rotterdam e Tilbury.

Alguns navios por vezes passaram também em alguns portos caribenhos como Philipsburg ou na região do mediterrâneo como Tanger Med.

Os navios da rota F serão separados em dois grupos:

- Grupo CMA CGM: CMA CGM Brazil, CMA CGM Cayenne, CMA CGM Marseille e CMA CGM Saint Laurente

- Grupo Marfret: Marfret Guyane e Marfret Marajo

A seguir temos a Tabela 19 com as características dos navios. Podemos ver pela tabela que os navios da CMA CGM foram construídos todos no ano de 2015 e os Marfret são um pouco mais velhos e com menor capacidade.

Tabela 17 - Características e estatísticas dos navios da rota seis

\begin{tabular}{lll} 
Nome do navio & Ano & TEUs \\
\hline CMA CGM BRAZIL & 2015 & 2350 \\
\hline CMA CGM CAYENNE & 2015 & 2140 \\
\hline CMA CGM MARSEILLE & 2015 & 2140 \\
\hline CMA CGM SAINT LAURENT & 2015 & 2140 \\
\hline MARFRET GUYANE & 2007 & 1691 \\
\hline MARFRET MARAJO & 2009 & 1691
\end{tabular}

Fonte: autoria própria

Como indica a Tabela 35, os navios do grupo CGM têm um tempo médio de rota no Brasil, considerando apenas os portos de Natal e Fortaleza, de 2 dias e um tempo médio de rota no exterior de 35,6 dias. E o número médio de viagens realizadas é de 9,2 viagens. 


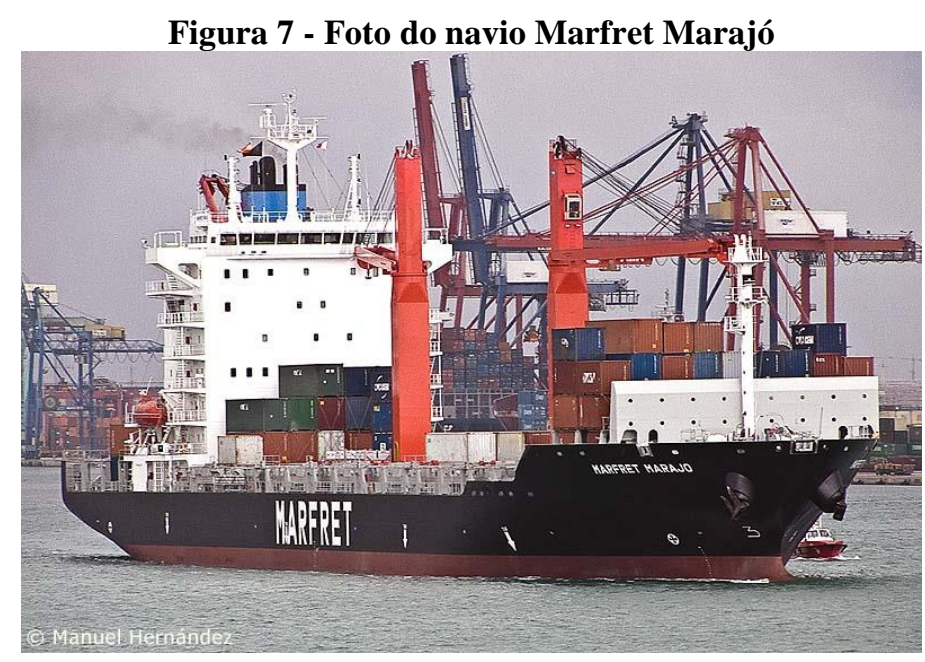

Fonte: MarineTraffic.com

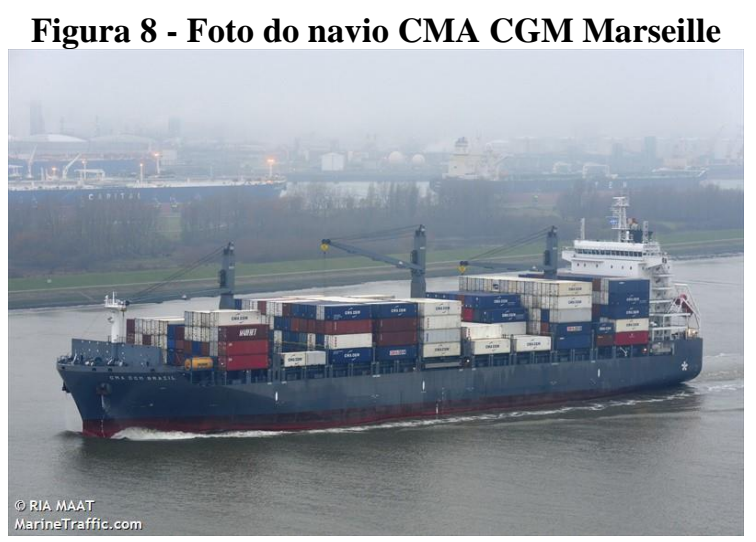

Fonte: MarineTraffic.com

A quantidade de viagens distintas, ou seja, a quantidade de vezes aproximada que cada navio atracou em cada porto está descrita na Tabela 45 contida no Apêndice.

Alguns navios desviaram algumas vezes das suas rotas habituais para atender esporadicamente demandas na Antuérpia, Lexões ou Tanger Med.

No apêndice também está a descrição do trajeto do navio CMA CGM Marseille.

Para calcular a oferta para a rota F, basta multiplicar a capacidade dos navios pelo número de viagens realizadas. Neste caso, foi utilizada para o grupo CGM CMA a capacidade da maior parte dos navios, uma vez que a diferença de capacidade entre os navios era bem pequena. 
Tabela 18 - Cálculo da oferta da rota 6

\begin{tabular}{llll}
\hline Grupo de navios & Capacidade (TEUs) & \# de navios & Viagens por ano \\
Grupo CGM CMA & 2140 & 4 & 9 \\
Grupo Mafret & 1691 & 2 & 9 \\
\hline
\end{tabular}

Fonte: autoria própria

\subsubsection{Navios "spot"}

Para os navios spot calculou-se a quantidade de viagens distintas que cada navio anunciou que faria passando por cada porto, ou seja, a quantidade de vezes aproximada que cada navio passou por cada porto. Uma tabela com todos os navios "spots" é apresentada no apêndice.

Para calcular a oferta que os navios "spot" ofereceram, basta multiplicar a capacidade dos navios pelo número de vezes que eles vieram para o Brasil, como mostra a Tabela 44, no apêndice $\mathrm{C}$.

\subsubsection{Outros navios}

Para o cálculo da oferta dos 81 navios restantes, foi averiguada a quantidade de vezes que eles atracaram no Porto de Santos.

A capacidade total de cada um dos navios foi calculada multiplicando a capacidade do navio pela metade do número de vezes que o navio atracou no Porto de Santos (a metade porque os navios geralmente atracam tanto no começo quanto no final da sua rota pelo Brasil no Porto de Santos, então faz sentido considerar apenas uma capacidade total de oferta a cada duas atracações). 


\subsection{Cálculo da oferta}

Agora que temos os valores da oferta para os três grandes grupos de navios (navios selecionados e identificados nas rotas descritas, navios que vieram para o Brasil de forma esporádica durante o período de análise e outros navios), é possível calcular um valor estimado para a oferta total de contêineres no transporte marítimo de longo curso no Brasil.

Vale ressaltar que o número de ciclos/viagens realizadas por navio no Brasil utilizado no cálculo da oferta dos navios selecionados e esporádicos, foi baseado no número de atracações anunciadas pelos navios (após a limpeza da base para descartar anúncios que foram posteriormente cancelados).

O cálculo da oferta pode ser observado na tabela 21 abaixo, que compilou todos os valores apresentados no capítulo anterior.

Tabela 19 - Cálculo da oferta

\begin{tabular}{lll}
\hline Grupo dos navios & \# de navios & Oferta (TEUs) \\
\hline Rota A & 17 & 1.322 .903 \\
\hline Rota B & 12 & 407.686 \\
\hline Rota C & 13 & 514.500 \\
\hline Rota D & 10 & 468.452 \\
\hline Rota E & 2 & Cabotagem \\
\hline Rota F & 6 & 107.478 \\
\hline Spot & 36 & 388.883 \\
\hline Outros & 81 & 2.281 .757 \\
\hline TOTAL & 177 & 5.491 .659
\end{tabular}

Fonte: autoria própria

A oferta do transporte de contêineres no Brasil entre Agosto de 2016 e Setembro de 2017, segundo o cálculo realizado nesta dissertação, pode ser aproximada para o valor de 5.491.659 contêineres. Se esse valor for multiplicado pela ocupação máxima dos navios de 80\%, um valor de aproximadamente 4,4 milhões de contêineres será obtido. 
Esse número representa a capacidade que os navios porta-contêineres que realizaram rotas de longo curso ao longo da costa brasileira durante o período estudado tiveram de transportar contêineres, levando-se em consideração a quantidade de ciclos (rotas passando pelo Brasil) que cada navio realizou, mas sem considerar a rotatividade dos contêineres durante um ciclo. Isto é, o valor considera apenas a capacidade total do navio de transporte e não a quantidade de contêineres que ele de fato movimentou ao atracar em diversos portos durante um ciclo.

As estimativas para o cálculo da oferta de cada um dos grupos foram explicadas no capítulo anterior. Vale ressaltar que os navios da rota $\mathrm{E}$ foram excluídos do cálculo por serem considerados navios de cabotagem e para essa análise estão sendo considerados apenas navios com rotas de longo curso.

Para efeito de validação do cálculo realizado, decidiu-se comparar os valores obtidos com a quantidade de contêineres movimentados entre Agosto de 2016 e Setembro de 2017 nos portos brasileiros segundo a ANTAQ (Agência Nacional do Transporte Aquaviário) e no Porto de Santos segundo os dados do próprio porto.

As seguintes análises foram realizadas para validar o valor:

- Análise 1: Comparar o valor de 4,4 milhões de capacidade total de oferta com o número real de contêineres movimentados no Brasil durante o mesmo período de tempo.

- Análise 2: Comparar o valor de 823.659 contêineres ofertados por alguns navios da Rota A (que passa pelo Porto de Santos) com o número real de contêineres movimentados pelos navios desta rota, no Porto de Santos, durante o período de tempo de estudo, para averiguar quanto da capacidade total dos navios o porto movimentou e descobrir qual a taxa de movimentação de contêineres durante um ciclo do navio.

Com essas duas análises é possível ter um valor estimado da rotatividade dos contêineres nos navios a cada ciclo realizado passando pela costa brasileira e, portanto, ter um entendimento melhor de como os números calculados na dissertação se aproximam da realidade.

A seguir é explicada a primeira análise: 
Segundo a ANTAQ (2017, p. 19), 9,2 milhões de contêineres foram movimentados no Brasil no ano de 2017 e 8,8 milhões de contêineres foram movimentados no Brasil no ano de 2016. Como o período de tempo estudado engloba metade de cada um dos anos, foi considerado 9,0 milhões de contêineres movimentados no Brasil para o período de tempo estudado, uma média dos dois valores.

Desse total, seguindo a proporção de navios de longo curso e cabotagem do ano de 2017 , $73 \%$ dos navios realizavam serviços de longo curso e $27 \%$ de cabotagem. Isso nos dá um valor de 6,57 milhões de contêineres movimentados por longo curso no período de estudo (ANTAQ, 2017).

Os 4,4 milhões de contêineres calculados nessa dissertação representam $66 \%$ dos 6,57 milhões de contêineres movimentados no Brasil. No entanto, é válido lembrar que no cálculo realizado aqui não foi considerada a movimentação dos contêineres nos portos durante um ciclo (uma rota do navio), isto é, não foi levado em consideração o carregamento e o descarregamento dos navios em cada porto pois não haviam dados suficientes para isso e o objetivo era encontrar um valor aproximado. Foi considerando apenas que ele carrega/descarrega $80 \%$ da sua capacidade total a cada ciclo que ele realiza. No entanto, vale indicar como sugestões para trabalhos futuros, calcular a oferta de contêineres levando-se em consideração o carregamento e o descarregamento dos navios.

Para entender um pouco melhor da movimentação de contêineres em cada porto foi realizada uma segunda análise.

Foi comparado o número de contêineres movimentados por alguns navios analisados pela rota A (embarcados e desembarcados) com a capacidade total de cada navio, para se obter uma estimativa do percentual da capacidade do navio que é movimentada por porto.

Ao somar todos os contêineres embarcados pelos navios selecionados da rota A durante o período de tempo analisado pela base, chegou-se ao valor de 311.292 contêineres. Ao se comparar esse valor com a oferta total calculada para esses navios de 823.659 contêineres, temse uma movimentação de embarque de contêineres de aproximadamente $38 \%$ da capacidade dos navios. 
Ao somar todos os contêineres removidos dos navios selecionados da rota A durante o período de tempo da análise da base, obteve-se o valor de 336.345 contêineres, o que representa $41 \%$ da capacidade dos navios.

Os cálculos da movimentação dos contêineres estão descritos na tabela 63 do apêndice F e tiveram como base os dados do próprio Porto de Santos.

Deve-se ter em mente que o Porto de Santos é o porto com maior movimentação de contêineres na América Latina, portanto, os outros portos provavelmente movimentam em média menos contêineres. Mas, considerando que o navio embarca e desembarca $40 \%$ da sua capacidade, ou seja, movimenta $80 \%$ da sua capacidade apenas no primeiro porto e ele ainda vai passar por outros portos e voltar para Santos antes de ir embora, o valor encontrado para a oferta calculada é condizente.

No entanto, como é sabido que o Porto de Santos é o principal porto da América Latina, e por isso movimenta mais contêineres que os outros portos, foram comparados os valores de contêineres movimentados no Porto de Santos com a movimentação dos outros para se ter uma estimativa mais aproximada da movimentação total comparada com a oferta total calculada. Segundo o Sistema de Desempenho Portuário da ANTAQ (2017), a quantidade de contêineres movimentados por navios de longo curso nas principais instalações portuárias brasileiras em 2017, foi a seguinte:

Tabela 20 - Quantidade de contêineres movimentados por navios de longo curso nas principais instalações portuárias brasileiras em 2017

\begin{tabular}{ll}
$\begin{array}{l}\text { Principais } \\
\text { instalações 2017 }\end{array}$ & $\begin{array}{l}\text { Contêineres movimentados (milhares de } \\
\text { TEUs) }\end{array}$ \\
\hline Santos & 2960 \\
\hline Portonave & 812 \\
\hline Paranaguá & 752 \\
\hline Rio Grande & 744 \\
\hline Embraport & 619 \\
\hline Itapoá & 592 \\
\hline Suape & 461 \\
\hline Salvador & 301 \\
\hline Rio de Janeiro & 283 \\
\hline Itaguaí & 281 \\
\hline Total & 7805
\end{tabular}

Fonte: ANTAQ (2017) 
A partir dessa tabela, pode-se estimar a movimentação de contêineres em cada um dos portos tendo como base o \% calculado para o Porto de Santos. Abaixo foram apresentados os cálculos para o \% de contêineres embarcados em cada porto tendo como base o Porto de Santos, mas a mesma comparação foi utilizada para o cálculo do \% de contêineres descarregados.

Tabela 21 - \% de contêineres embarcados em cada porto

\begin{tabular}{lll}
\hline Portos & $\begin{array}{l}\text { Comparação da movimentação } \\
\text { de contêineres dos portos com o } \\
\text { Porto de Santos }\end{array}$ & $\begin{array}{l}\text { \% de contêineres embarcados } \\
\text { em cada porto tendo como } \\
\text { base o Porto de Santos }\end{array}$ \\
\hline Santos & $100 \%$ & $38 \%$ \\
\hline Portonave & $27 \%$ & $10 \%$ \\
\hline Paranaguá & $25 \%$ & $10 \%$ \\
\hline Rio Grande & $25 \%$ & $10 \%$ \\
\hline Embraport & $21 \%$ & $8 \%$ \\
\hline Itapoá & $20 \%$ & $8 \%$ \\
\hline Suape & $16 \%$ & $6 \%$ \\
\hline Salvador & $10 \%$ & $4 \%$ \\
\hline Rio de Janeiro & $10 \%$ & $4 \%$ \\
\hline Itaguaí & $9 \%$ & $4 \%$ \\
\hline Font Autoria
\end{tabular}

Fonte: Autoria Própria

No entanto, para compreender o percentual estimado de movimentação de contêineres em comparação com a capacidade das embarcações para os navios selecionados da rota A, deve-se comparar a movimentação desses navios no Porto de Santos com a movimentação de todos os outros portos pertencentes à rota A. Desta forma, fez-se necessário usar os dados do CEPAL (2017), para comparar a movimentação no Porto de Santos com os portos de Montevideo e Buenos Aires. Os valores abaixo são referentes ao ano de 2016.

Tabela 22 - Contêineres movimentados

\begin{tabular}{ll}
\hline Portos & $\begin{array}{l}\text { Contêineres } \\
\text { movimentados } \\
\text { (milhares de TEUs) }\end{array}$ \\
\hline Santos & 3.393 .593 \\
\hline Montevideo & 888.119 \\
\hline $\begin{array}{l}\text { Buenos } \\
\text { Aires }\end{array}$ & 1.352 .068 \\
\hline Total & 5.633 .780 \\
\hline
\end{tabular}

Fonte: Autoria Própria

A partir dessa tabela, pode-se estimar a movimentação de contêineres em cada um dos portos tendo como base o \% calculado para o Porto de Santos. 
Tabela 23 - Movimentação de contêineres em cada um dos portos

\begin{tabular}{lll}
\hline Portos & $\begin{array}{l}\text { \% de contêineres movimentados } \\
\text { em cada porto considerando-se } \\
\text { os 3 portos da lista }\end{array}$ & $\begin{array}{l}\text { Quanto a movimentação dos } \\
\text { portos representa da } \\
\text { movimentação do Porto de Santos }\end{array}$ \\
\hline Santos & $60 \%$ & $100 \%$ \\
\hline Montevideo & $16 \%$ & $26 \%$ \\
\hline Buenos Aires & $24 \%$ & $40 \%$ \\
\hline
\end{tabular}

Fonte: Autoria Própria

Desta forma, com base na movimentação real de contêineres no Porto de Santos e na proporção da movimentação real total de contêineres nos outros portos em relação ao Porto de Santos, foi possível estimar a movimentação de contêineres nos navios da rota A em relação à capacidade total deles:

Tabela 24 - Movimentação de contêineres nos navios da rota $\mathrm{A}$ em relação à capacidade total dos mesmos

\begin{tabular}{lll}
\hline $\begin{array}{l}\text { Portos brasileiros } \\
\text { que compõe a rota A }\end{array}$ & $\begin{array}{l}\text { \% de contêineres embarcados se } \\
\text { comparados com a capacidade } \\
\text { total dos navios da rota 1 }\end{array}$ & $\begin{array}{l}\text { \% de contêineres descarregados } \\
\text { se comparados com a capacidade } \\
\text { total dos navios da rota 1 }\end{array}$ \\
\hline Santos & $38 \%$ & $41 \%$ \\
\hline Paranaguá & $10 \%$ & $11 \%$ \\
\hline Buenos Aires & $15 \%$ & $16 \%$ \\
\hline Montevideo & $10 \%$ & $11 \%$ \\
\hline Rio Grande & $10 \%$ & $11 \%$ \\
\hline Itapoá & $8 \%$ & $9 \%$ \\
\hline Paranaguá & $10 \%$ & $11 \%$ \\
\hline Santos & $38 \%$ & $41 \%$ \\
\hline Total & $\mathbf{1 3 9} \%$ & $\mathbf{1 5 0} \%$ \\
\hline
\end{tabular}

Fonte: Autoria Própria

Portanto, para a rota A, por exemplo, utilizando como base de comparação as movimentações nos portos comparadas à movimentação do Porto de Santos, a rotatividade seria de $239 \%$ para os portos brasileiros.

Esse número de $239 \%$ é maior que a relação de $149 \%$ dos 4,4 milhões contêineres movimentados calculados com os 6,57 milhões contêineres realmente movimentados, mas o parâmetro utilizado foi o Porto de Santos, o principal porto da América Latina. Portanto, a rotatividade não deve ser em média tão alta. Esse número se fazia importante apenas para confirmar que a rotatividade seria maior por ciclo do que os $80 \%$ da capacidade máxima do navio, utilizado para o cálculo. 


\section{Análise dos resultados obtidos}

Com vistas a descrever e caracterizar a forma como se dá a oferta de contêineres no transporte marítimo brasileiro, convém versar a respeito dos seguintes questionamentos:

(a) As rotas que os navios realizam são regulares como afirma a literatura?

(b) Os navios atracam em todos os portos com a mesma frequência ou existem portos principais e portos secundários?

(c) Se existem duas companhias marítimas com serviços a serem entregues nos portos da mesma rota e em datas muito próximas, será que ambas iniciarão suas rotas com os navios pouco ocupados ao invés de juntar suas mercadorias e fazer com que um navio sirva as duas empresas?

(d) Caso, após a programação da rota, não tenha havido muita demanda em um determinado porto ou aconteça algum imprevisto que pode atrasar o restante da rota, será que o navio atracará no porto de qualquer forma (tendo firmado um acordo com os proprietários da mercadoria) ou seguirá direto para o próximo porto da rota para otimizar o serviço?

Partindo do resultado das análises apresentadas no presente estudo, é possível formular algumas respostas para essas perguntas, a saber:

(a) As rotas dos navios não são tão regulares como afirma a literatura. Elas são influenciadas pela demanda e a demanda depende de inúmeros fatores, tais como: a época do ano, a logística interna das empresas mais representativas nas embarcações (com maior quantidade de carga), a infraestrutura dos portos, entre outras coisas.

(b) Existem portos principais e portos secundários. Nos primeiros, os navios atracam com muito mais frequência do que no segundo grupo.

(c) As companhias marítimas estão se organizando e combinando coisas entre si de forma a afretar espaços nos navios para conseguir adequar a oferta à demanda $\mathrm{e}$ evitar que o preço do frete fique muito baixo. 
(d) Os navios estão desistindo de atracar em portos nos quais anunciaram que atracariam. Muito provavelmente por causa da falta de demanda na região e da falha infraestrutura dos portos. Isto é, a baixa demanda e a dificuldade estrutural tornam a atracação em alguns portos economicamente desfavorável, o que faz com que as embarcações apenas desistam de atracar nos portos durante o trajeto e acabem prejudicando os pequenos embarcadores.

\subsection{As rotas realizadas pelas embarcações não são fixas}

Abaixo uma breve definição de STOPFORD ${ }^{51}$, a respeito das linhas regulares:

"Um serviço de linhas regulares é uma frota de navios, com um proprietário ou um gerenciamento comum, que oferece um serviço fixo, em intervalos de tempo regulares, entre os portos nomeados e fornece o transporte a quaisquer mercadorias na área de influência servida por esses portos e pronta para viajar segundo as suas datas. Os aspectos que distinguem um serviço de linhas regulares de um serviço de linhas não regulares são um itinerário fixo, a inclusão num serviço regular e a obrigação de aceitar a carga de todos que apareçam e navegar, cheio ou não, na data determinada por uma programação publicada".

Ocorre que utilizando uma base de dados real isso não se comporta dessa maneira. Segundo NOTTEBOOM ${ }^{52}$, talvez apenas gerenciar o fator tempo na operação de serviços lineares e desenvolver redes de serviços caracterizadas pelos custos baixos de operação, altas frequências, rápidos tempos em trânsito e ambos, rigorosos e confiáveis cronogramas de viagem não sejam suficientes para adequar as companhias marítimas aos requisitos de otimização do mundo cada vez mais globalizado. As companhias estão cada vez mais engajadas em melhorar seus serviços e isso inclui adaptar seus cronogramas antes rigorosos e fixos à demanda sazonal, diminuir ou aumentar a frequência nos portos, fazer rotas variáveis ao longo do ano para atender diferentes mercados (atender aqueles com maior demanda em determinada época do ano),

\footnotetext{
51 STOPFORD (2009)

${ }^{52}$ NOTTEBOOM, (2006)
} 
trabalhar cada vez mais com o afretamento de espaço entre companhias para minimizar os custos com o transporte de mercadorias, entre outras coisas.

Da base, pôde-se extrair a Tabela 27 que apresenta como são poucos os navios que realizam uma rota fixa durante todo o ano independente da demanda a qual eles estão servindo:

Tabela 25 - Número de navios por tipo de rota

\begin{tabular}{lll}
\hline & Número de navios & \% de navios \\
\hline Rota fixa & 40 & $42 \%$ \\
\hline Rota variável & 18 & $19 \%$ \\
\hline Spots & 36 & $37 \%$ \\
\hline Cabotagem & 2 & $2 \%$ \\
\hline
\end{tabular}

Fonte: autoria própria

Ao analisarmos a rota A, por exemplo, existem muitos navios que realizam uma rota fixa Brasil-Europa, como o Cap San Antonio, San Artemissio e a maioria dos navios da Cap. Em compensação, o Navio Cezanne tem uma rota bem variável ao longo do ano.

Na rota dois, por sua vez, enquanto o MSC Krystal realiza uma rota bem regular, o MSC Fiammetta que antes passava apenas pela Europa, começou em março de 2017 a realizar uma rota que passava pelo Brasil também.

A seguir, dois exemplos para comparação. 
Tabela 26 - Parte da rota do Cap San Antonio durante os anos de 2016 e 2017

\begin{tabular}{|c|c|c|c|c|c|}
\hline Porto & Data & & & & \\
\hline Santos & $11 / 08 / 2016$ & London Gateway Port & $11 / 11 / 2016$ & London Gateway Port & $04 / 03 / 2017$ \\
\hline Paranagua & $13 / 08 / 2016$ & Hamburg & $13 / 11 / 2016$ & Hamburg & 05/03/2017 \\
\hline Buenos Aires & $17 / 08 / 2016$ & Antwerpen & $16 / 11 / 2016$ & Antwerpen & $08 / 03 / 2017$ \\
\hline Montevideo & $19 / 08 / 2016$ & Le Havre & $17 / 11 / 2016$ & Le Havre & $10 / 03 / 2017$ \\
\hline Rio Grande & $21 / 08 / 2016$ & Santos & $01 / 12 / 2016$ & Santos & $23 / 03 / 2017$ \\
\hline Itapoa & $24 / 08 / 2016$ & Paranagua & $03 / 12 / 2016$ & Paranagua & $25 / 03 / 2017$ \\
\hline Paranagua & $25 / 08 / 2016$ & Buenos Aires & $06 / 12 / 2016$ & Buenos Aires & $29 / 03 / 2017$ \\
\hline Santos & $27 / 08 / 2016$ & Montevideo & $09 / 12 / 2016$ & Montevideo & $31 / 03 / 2017$ \\
\hline Tanger Med & $10 / 09 / 2016$ & Rio Grande & $11 / 12 / 2016$ & Rio Grande & $02 / 04 / 2017$ \\
\hline $\begin{array}{l}\text { Rotterdam } \\
\text { London }\end{array}$ & $14 / 09 / 2016$ & Itapoa & $14 / 12 / 2016$ & Itapoa & $05 / 04 / 2017$ \\
\hline Gateway Port & $16 / 09 / 2016$ & Paranagua & $16 / 12 / 2016$ & Paranagua & $06 / 04 / 2017$ \\
\hline Hamburg & $18 / 09 / 2016$ & Santos & $18 / 12 / 2016$ & Santos & $08 / 04 / 2017$ \\
\hline Antwerpen & $20 / 09 / 2016$ & Tanger Med & $01 / 01 / 2017$ & Tanger Med & $24 / 04 / 2017$ \\
\hline Le Havre & $22 / 09 / 2016$ & Rotterdam & $05 / 01 / 2017$ & Rotterdam & $27 / 04 / 2017$ \\
\hline Santos & $06 / 10 / 2016$ & London Gateway Port & $06 / 01 / 2017$ & London Gateway Port & $29 / 04 / 2017$ \\
\hline Paranagua & 09/10/2016 & Hamburg & 08/01/2017 & Hamburg & $01 / 05 / 2017$ \\
\hline Buenos Aires & $13 / 10 / 2016$ & Antwerpen & $10 / 01 / 2017$ & Antwerpen & $04 / 05 / 2017$ \\
\hline Montevideo & $15 / 10 / 2016$ & Le Havre & $13 / 01 / 2017$ & Le Havre & $06 / 05 / 2017$ \\
\hline Rio Grande & $17 / 10 / 2016$ & Santos & $26 / 01 / 2017$ & Santos & $18 / 05 / 2017$ \\
\hline Itapoa & $19 / 10 / 2016$ & Paranagua & $28 / 01 / 2017$ & Paranagua & $20 / 05 / 2017$ \\
\hline Paranagua & $21 / 10 / 2016$ & Buenos Aires & $31 / 01 / 2017$ & Buenos Aires & $23 / 05 / 2017$ \\
\hline Santos & $22 / 10 / 2016$ & Montevideo & $02 / 02 / 2017$ & Montevideo & $25 / 05 / 2017$ \\
\hline Tanger Med & $05 / 11 / 2016$ & Rio Grande & $04 / 02 / 2017$ & Rio Grande & $28 / 05 / 2017$ \\
\hline \multirow[t]{5}{*}{ Rotterdam } & $09 / 11 / 2016$ & Itapoa & 07/02/2017 & Itapoa & $30 / 05 / 2017$ \\
\hline & & Paranagua & $10 / 02 / 2017$ & Paranagua & $01 / 06 / 2017$ \\
\hline & & Santos & $11 / 02 / 2017$ & Santos & $03 / 06 / 2017$ \\
\hline & & Tanger Med & $25 / 02 / 2017$ & Tanger Med & $17 / 06 / 2017$ \\
\hline & & Rotterdam & $01 / 03 / 2017$ & Rotterdam & $21 / 06 / 2017$ \\
\hline
\end{tabular}


Tabela 27 - Parte da rota do MSC Fiammetta, navio da rota B, durante os anos de 2016 e 2017

\begin{tabular}{ll}
\hline Porto & Data \\
\hline Felixstowe & $06 / 08 / 2016$ \\
Bremerhaven & $07 / 08 / 2016$ \\
\hline Hamburg & $08 / 08 / 2016$ \\
\hline \hline Antwerpen & $11 / 08 / 2016$ \\
Rotterdam & $23 / 08 / 2016$ \\
\hline Hamburg & $25 / 08 / 2016$ \\
\hline \hline Bremerhaven & $27 / 08 / 2016$ \\
Le Havre & $29 / 08 / 2016$ \\
Lisboa & $01 / 09 / 2016$ \\
Sines & $02 / 09 / 2016$ \\
Felixstowe & $04 / 09 / 2016$ \\
Bremerhaven & $05 / 09 / 2016$ \\
\hline Hamburg & $07 / 09 / 2016$ \\
\hline \hline Antwerpen & $09 / 09 / 2016$ \\
Felixstowe & $02 / 10 / 2016$ \\
Bremerhaven & $04 / 10 / 2016$ \\
\hline Hamburg & $05 / 10 / 2016$ \\
\hline \hline Antwerpen & $07 / 10 / 2016$ \\
Felixstowe & $30 / 10 / 2016$ \\
Bremerhaven & $01 / 11 / 2016$ \\
\hline Hamburg & $02 / 11 / 2016$ \\
\hline \hline Antwerpen & $05 / 11 / 2016$ \\
\hline Hamburg & $27 / 11 / 2016$ \\
\hline \hline Bremerhaven & $29 / 11 / 2016$ \\
Felixstowe & $01 / 12 / 2016$ \\
Antwerpen & $02 / 12 / 2016$ \\
London Gateway Port & $27 / 12 / 2016$ \\
\hline Hamburg & $28 / 12 / 2016$ \\
\hline \hline Bremerhaven & $31 / 12 / 2016$ \\
Antwerpen & $05 / 01 / 2017$ \\
Felixstowe & $29 / 01 / 2017$ \\
Bremerhaven & $31 / 01 / 2017$ \\
\hline Hamburg & $01 / 02 / 2017$ \\
\hline Antwerpen & $28 / 02 / 2017$ \\
Felixstowe & \\
Bremerhaven & \\
\hline & $02 / 2017$ \\
\hline
\end{tabular}

\begin{tabular}{ll}
\hline Hamburg & $01 / 03 / 2017$ \\
\hline \hline Antwerpen & $04 / 03 / 2017$ \\
Antwerpen & $04 / 04 / 2017$ \\
Le Havre & $07 / 04 / 2017$ \\
Lisboa & $09 / 04 / 2017$ \\
Sines & $11 / 04 / 2017$ \\
\hline RJ & $20 / 04 / 2017$ \\
Santos & $22 / 04 / 2017$ \\
Paranagua & $23 / 04 / 2017$ \\
Navegantes & $24 / 04 / 2017$ \\
Santos & $27 / 04 / 2017$ \\
RJ & $30 / 04 / 2017$ \\
Salvador & $02 / 05 / 2017$ \\
\hline \hline Antwerpen & $16 / 05 / 2017$ \\
Rotterdam & $17 / 05 / 2017$ \\
Hamburg & $19 / 05 / 2017$ \\
Bremerhaven & $22 / 05 / 2017$ \\
Le Havre & $25 / 05 / 2017$ \\
Lisboa & $29 / 05 / 2017$ \\
Sines & $30 / 05 / 2017$ \\
\hline RJ & $08 / 06 / 2017$ \\
Santos & $09 / 06 / 2017$ \\
Navegantes & $11 / 06 / 2017$ \\
Paranagua & $11 / 06 / 2017$ \\
Santos & $15 / 06 / 2017$ \\
RJ & $17 / 06 / 2017$ \\
Salvador & $20 / 06 / 2017$ \\
\hline \hline Antwerpen & $04 / 07 / 2017$ \\
Rotterdam & $05 / 07 / 2017$ \\
Hamburg & $07 / 07 / 2017$ \\
Bremerhaven & $11 / 07 / 2017$ \\
Le Havre & $13 / 07 / 2017$ \\
Lisboa & $15 / 07 / 2017$ \\
Sines & $16 / 07 / 2017$ \\
\hline RJ & $27 / 07 / 2017$ \\
Santos & $28 / 07 / 2017$ \\
Paranagua & $29 / 07 / 2017$ \\
Navegantes & $31 / 07 / 2017$ \\
Salvador & $08 / 08 / 2017$ \\
\hline \hline
\end{tabular}

Fonte: autoria própria

É válido lembrar que mesmo os navios que realizam rotas "regulares" por vezes não escalam alguns portos que são considerados da sua rota e que os navios que realizam rotas "variáveis" também diferem entre si com relação à variabilidade das suas rotas. O MSC Fiammetta é um exemplo de navio que alterou sua rota ao longo do ano. 
As rotas mais regulares estão associadas aos navios com maiores capacidades e são controlados pelos maiores armadores.

\subsection{Existem portos principais e portos secundários}

Com a análise da base é possível identificar que existem portos principais e portos secundários nas rotas. Os navios atracam com muito mais frequência nos portos principais do que nos portos secundários, como pode ser observado na seguinte análise:

Tabela 28 - Quantidade de vezes que alguns dos navios do grupo Cap da rota 1 anunciaram que atracariam nos portos

\begin{tabular}{lllll}
\hline & CAP SAN & CAP SAN & CAP SAN & CAP SAN \\
Nome Navio & ANTONIO & ARTEMISSIO & AUGUSTIN & LORENZO \\
\hline Algeciras & 4 & 5 & 3 & 4 \\
\hline Antwerpen & 21 & 19 & 22 & 19 \\
\hline Bremerhaven & 4 & 5 & 3 & 4 \\
\hline Buenos_Aires & 25 & 18 & 25 & 21 \\
\hline Hamburg & 20 & 22 & 22 & 19 \\
\hline Itajai & 5 & 6 & 4 & 5 \\
\hline Itapoa & 24 & 22 & 26 & 22 \\
\hline Le_Havre & 21 & 19 & 22 & 19 \\
\hline London & 7 & 7 & 8 & 7 \\
\hline London_Gateway_Port & 20 & 20 & 22 & 19 \\
\hline Montevideo & 25 & 18 & 25 & 21 \\
\hline Paranagua & 25 & 21 & 26 & 21 \\
\hline Pecem & 4 & 6 & 3 & 5 \\
\hline Rio_Grande & 25 & 21 & 25 & 20 \\
\hline Rotterdam & 22 & 24 & 24 & 20 \\
\hline Santos & 25 & 21 & 26 & 21 \\
\hline Tanger_Med & 9 & 9 & 10 & 11 \\
\hline Tangier & 14 & 14 & 16 & 14 \\
\hline Tanjung_Priok & 6 & 5 & 6 & 7 \\
\hline Tilbury & 4 & 5 & 3 & 4 \\
\hline Fonte: & & & & \\
\hline
\end{tabular}

\section{Fonte: autoria própria}

Pode-se perceber que os portos principais são Itapoá, Paranaguá, Santos e Rio Grande, enquanto Pecém e Itajaí são portos secundários.

Uma explicação provável é a de que as empresas controladoras dos navios muitas vezes decidem não parar nos portos secundários principalmente por dois motivos:

- Demanda: muitas vezes não compensa atracar naquele porto, já que se tem pouca carga para descarregar ali. Os motivos para não ter muita carga para descarregar ali 
provavelmente consideram a infraestrutura do porto, a logística interna que será realizada após o descarregamento da carga, os impostos a serem cobrados naquela região, entre outras coisas.

- A infraestrutura do próprio porto: muitos portos ficam fechados por problemas técnicos por alguns dias e o custo para o navio esperar o porto abrir é muito alto.

\subsection{As companhias marítimas estão se organizando de forma a afretar espaços dentro das embarcações para diversas transportadoras}

Deve-se entender como serviço, o contrato que uma empresa firma com uma afretadora para transportar uma quantidade determinada de carga de um porto de origem a um porto de destino com um prazo máximo de entrega pré-determinado.

Existem três grupos envolvidos diretamente no serviço do transporte de um contêiner: o dono do navio, a transportadora e o dono da carga. Em muitas situações a transportadora é dona do navio, ou o dono da carga é a própria transportadora e tem o próprio navio, muitas são as situações que podem acontecer.

Com a análise da base pode-se notar que o nome da transportadora está cada vez menos associado ao dono do navio. Muitos navios carregam cargas de mais de uma transportadora. Por exemplo, o navio CMA CGM BRAZIL, carrega cargas da CMA-CGM, Aliança, HamburgSüd, Hyundai, Maersk, MSC e Safmarine.

A Tabela 31 ilustra isso ao mostrar que a maioria dos navios está associado a mais de uma transportadora. 
Tabela 29 - Quantidade de transportadoras por navios

\begin{tabular}{|c|c|}
\hline Navio & \# \\
\hline Amazonia & 1 \\
\hline Bf Caroda & 4 \\
\hline Cap San Antonio & 9 \\
\hline Cap San Artemissio & 9 \\
\hline Cap San Augustin & 9 \\
\hline Cap San Lorenzo & 9 \\
\hline Cap San Maleas & 9 \\
\hline Cap San Marco & 9 \\
\hline Cap San Nicolas & 9 \\
\hline Cap San Raphael & 9 \\
\hline Cezanne & 4 \\
\hline Cma Cgm Brazil & 2 \\
\hline Cma Cgm Cayenne & 2 \\
\hline Cma Cgm Marseille & 2 \\
\hline Cma Cgm Saint Laurent & 2 \\
\hline Dali & 2 \\
\hline Durande & 4 \\
\hline E. R. London & 8 \\
\hline Ebba Maersk & 6 \\
\hline Eleonora Maersk & 5 \\
\hline Elly Maersk & 6 \\
\hline Emma Maersk & 6 \\
\hline Estelle Maersk & 6 \\
\hline Eugen Maersk & 6 \\
\hline Helga & 7 \\
\hline Maersk Genoa & 2 \\
\hline Maersk Gibraltar & 2 \\
\hline Maersk Guayaquil & 2 \\
\hline Maersk Kobe & 3 \\
\hline Maersk Laberinto & 5 \\
\hline Maersk Labrea & 5 \\
\hline Maersk Lamanai & 6 \\
\hline
\end{tabular}

\begin{tabular}{|c|c|}
\hline Maersk Lanco & 6 \\
\hline Maersk Leon & 7 \\
\hline Maersk Lima & 5 \\
\hline Maersk Lins & 5 \\
\hline Maersk Lota & 5 \\
\hline Maersk Saltoro & 2 \\
\hline Maersk Sarat & 2 \\
\hline Maersk Shams & 2 \\
\hline Maersk Stadelhorn & 2 \\
\hline Marfret Guyane & 2 \\
\hline Marfret Marajo & 2 \\
\hline Max Loyalty & 7 \\
\hline Mol Genesis & 12 \\
\hline Msc Agadir & 3 \\
\hline Msc Ajaccio & 2 \\
\hline Msc Alicante & 10 \\
\hline Msc Amalfi & 2 \\
\hline Msc Amsterdam & 6 \\
\hline Msc Anna & 6 \\
\hline Msc Arica & 2 \\
\hline Msc Azov & 2 \\
\hline Msc Barbara & 9 \\
\hline Msc Barcelona & 10 \\
\hline Msc Cadiz & 10 \\
\hline Msc Carolina & 7 \\
\hline Msc Coruna & 10 \\
\hline Msc Eloane & 6 \\
\hline Msc Emanuela & 3 \\
\hline Msc Erica & 6 \\
\hline Msc Fiammetta & 6 \\
\hline Msc Gaia & 7 \\
\hline Msc Geneva & 4 \\
\hline Msc Hamburg & 5 \\
\hline
\end{tabular}

\begin{tabular}{|c|c|}
\hline Msc Ilona & 4 \\
\hline Msc Istanbul & 5 \\
\hline Msc Judith & 3 \\
\hline Msc Julie & 3 \\
\hline Msc Kalamata & 3 \\
\hline Msc Katyayni & 7 \\
\hline Msc Kingston & 3 \\
\hline Msc Kolkata & 3 \\
\hline Msc Krystal & 8 \\
\hline Msc Letizia & 3 \\
\hline Msc Madrid & 11 \\
\hline Msc Margarita & 10 \\
\hline Msc Marianna & 9 \\
\hline Msc Marina & 8 \\
\hline Msc Marta & 11 \\
\hline Msc Meline & 2 \\
\hline Msc Mirjam & 6 \\
\hline Msc Oriane & 9 \\
\hline Msc Soraya & 7 \\
\hline Msc Venice & 7 \\
\hline Msc Vidhi & 11 \\
\hline Msc Vigo & 11 \\
\hline Northern Majestic & 6 \\
\hline Pantanal & 1 \\
\hline Rhodos & 9 \\
\hline Rio Barrow & 8 \\
\hline Rio De Janeiro & 11 \\
\hline Rio Negro & 10 \\
\hline Widukind & 3 \\
\hline Wms Harlingen & 5 \\
\hline X-Press Mulhacen & 7 \\
\hline
\end{tabular}

Fonte: autoria própria

Segundo Stopford (2009), o transporte de mercadorias através de contêineres, forma um mercado muito dependente da oferta e da demanda, uma vez que é regulado por essas duas variáveis econômicas em conjunto com a taxa de frete. Se a oferta de navios é alta, maior que 
a demanda, o preço da taxa de frete cai; por outro lado, se a demanda por navios está maior do que a oferta, as transportadoras podem cobrar um preço maior pelo serviço.

Tanto a oferta quanto a demanda do mercado marítimo variam muito, o que faz com que o preço também oscile bastante. Existem dois principais fatores que influenciam negativamente a demanda: a sazonalidade e os períodos de crise.

Conforme o modelo do sistema de transporte de linhas regulares de Stopford (2009), existem três formas principais de oferecimento dos serviços de linhas regulares:

1-) Companhias de linhas regulares: fornecem serviços de linhas regulares, utilizando navios próprios, complementados por navios afretados;

2-) Alianças: grupos de companhias que operam uma rede conjunta de serviços globais, por exemplo, a Grand Alliance;

3-) Afretamento de espaços: as companhias de linhas regulares fretam espaços nos serviços a outras companhias.

Pode-se inferir pela análise da base que, a estratégia das companhias foi se organizar para diminuir a oferta do mercado diminuindo o número de navios que realizavam a mesma rota, isto é, afretando espaço. Se antes três navios de três companhias diferentes realizavam a mesma rota no mesmo período, agora apenas um navio realiza essa rota e as duas companhias que tiraram seus navios desta rota enviam seus serviços pelo navio de outra companhia, isto é, afretando espaço. Com isso, as empresas estão consolidando o mercado e tornando possível manter um preço mais alto de frete.

\subsection{As companhias marítimas estão desistindo de atracar em alguns portos e isso atrapalha os pequenos e médios embarcadores}

O transporte marítimo brasileiro vem enfrentando uma polêmica discussão. Muitos navios desistem de atracar nos portos, isto é, deixam de atracar nos portos nos quais já haviam 
anunciado que atracariam, prejudicando pequenos e médios embarcadores que teriam suas cargas transportadas.

A base de dados evidencia o fato de que muitas vezes os navios anunciam que vão atracar nos portos e depois desistem. Eles oferecem o serviço provavelmente para saber se terão demanda, mas durante a rota apenas desistem de atracar e nos próximos anúncios da rota não consta mais a escala nesses portos. Isso se torna ainda mais prejudicial aos pequenos e médios embarcadores quando as decisões são tomadas com as cargas já embarcadas.

A seguir temos um exemplo:

Tabela 30 - Exemplo de navio que deixou de escalar em um porto que havia anunciado que escalaria

\begin{tabular}{llll}
$\begin{array}{l}\text { Nome } \\
\text { Porto }\end{array}$ & TEC & TEP & Data de anúncio \\
\hline Santos & $18 / 04 / 2017$ & $18 / 04 / 2017$ & $03 / 04 / 2017$ 00:03 \\
\hline Pecem & $24 / 04 / 2017$ & $24 / 04 / 2017$ & $03 / 04 / 2017$ 00:03 \\
\hline Santos & $26 / 04 / 2017$ & $26 / 04 / 2017$ & $08 / 04 / 201723: 08$
\end{tabular}

Fonte: Autoria Própria

Como apresentado na tabela 32, em 03.04.2017 o navio anunciou que atracaria em Santos e Pecém, no entanto, no dia 08.04.2017 (data da próxima comunicação com o navio), ele anunciou que atracaria apenas em Santos, excluindo o porto de Pecém da rota.

Tabela 31 - Exemplo de navio que deixou de escalar em um porto que havia anunciado que escalaria

\begin{tabular}{llll}
\hline $\begin{array}{l}\text { Nome } \\
\text { Porto }\end{array}$ & TEC & TEP & Data de anúncio \\
\hline Itajai & $03 / 06 / 2017$ & $03 / 06 / 2017$ & Anúncio1 \\
\hline Santos & $13 / 06 / 2017$ & $13 / 06 / 2017$ & Anúncio1 \\
\hline Santos & $03 / 06 / 2017$ & $03 / 06 / 2017$ & Anúncio2 \\
\hline
\end{tabular}

Fonte: Autoria Própria

O mesmo que ocorreu com o porto de Pecém se passou com o de Itajaí. No entanto, no exemplo trocamos a data exata para que se possa identificar os diferentes anúncios que foram realizados.

A hipótese é a de que os donos dos navios desistem de atracar nos portos secundários principalmente por dois motivos: 
- Falta de demanda: muitas vezes não compensa financeiramente atracar naquele porto, já que se tem pouca carga para descarregar. Os motivos para não ter muita carga para descarregar ali provavelmente consideram a logística interna que será realizada após o descarregamento da carga, os impostos a serem cobrados naquela região, entre outras coisas.

- A infraestrutura do próprio porto: muitos portos não fornecem uma infraestrutura que otimiza os custos dos armadores que terão que atracar seus navios nos portos. Os portos ficam fechados por problemas técnicos por alguns dias e o custo para o navio esperar o porto abrir ou ficar em fila é muito alto.

As denúncias apontam que os armadores se dão o direito de não atracar em portos nos quais estavam previstas atracações e os usuários não dispõem de meios suficientes para contrapô-los, dado que eles são os donos dos navios e ameaçam colocar os usuários em listas restritivas, se recusando a transportar novamente seus produtos.

Recentemente a ANTAQ ${ }^{53}$ soltou uma Resolução Normativa - RN nº18, publicada no Diário Oficial da União em 26 de dezembro de 2017 - que, trata sobre os direitos e deveres dos usuários, dos agentes intermediários e das empresas que operam nas navegações de apoio marítimo, apoio portuário, cabotagem e longo curso, e, tendo por objetivo primordial garantir a qualidade do serviço marítimo prestado, também impõe regras direcionadas à redução do número de supressões de escala sem justificativa, de forma a contribuir para a reversão do cenário acima exposto e para minimizar o prejuízo sofrido pelos pequenos e médios usuários, muito afetados por tal prática. Assim, tais usuários passam a ter à sua disposição instrumentos legais potencialmente capazes de lhes permitir que façam valer os seus direitos.

Como pontuado pela própria $\mathrm{ANTAQ}^{54}$, representando um marco no amadurecimento regulatório da navegação marítima e de apoio e na tutela do direito dos usuários desse serviço, a Resolução Normativa No 18/2017, além de tratar expressamente das condições de adequação do serviço prestado, a serem observadas permanentemente pelos transportadores marítimos e

\footnotetext{
${ }^{53}$ ANTAQ (Agência Nacional do Transporte Aquaviário)

${ }^{54}$ Portal.antaq
} 
agentes intermediários, impõe deveres a serem cumpridos por eles em caso de supressão de escala.

Nesse sentido, dispõe:

Art. 14. Em caso de supressão de escala, os transportadores marítimos e os agentes intermediários deverão adotar as medidas necessárias para a entrega da carga no destino acordado, cumprindo o critério de pontualidade, sem a cobrança de custos extras para o usuário, salvo nas situações de avaria grossa

Ao determinar que nesses casos (de supressão de escala) os transportadores marítimos e agentes intermediários devem adotar as medidas que forem necessárias para garantir a entrega da carga no destino acordado - em observância ao prazo estabelecido (pontualidade) e sem cobranças adicionais -, a resolução da ANTAQ contribui significativamente para proteger juridicamente os interesses e direitos dos usuários do serviço de transporte que poderiam ser prejudicados pelo arbítrio do transportador em optar por não mais parar em determinado porto.

Por força de tal artigo, mesmo que os armadores optem por alterar os portos nos quais vão atracar, devem garantir que a carga seja entregue da forma previamente acordada, o que garante que os pequenos e médios embarcadores que contrataram com tais armadores irão ter acesso.

Ao longo do ano de 2018 foram realizadas algumas reuniões do Comitê Técnico de Comércio Exterior e Fiscal - Comitec, que contaram com a participação do diretor geral da Agência Nacional de Transportes Aquaviários - Antaq, além do presidente do SINDICMIS/ACTC, do diretor executivo da Entidade, entre outras pessoas, cujas pautas centrais foram a Resolução Normativa ${ }^{\circ} 18$.

Em uma das reuniões, Mario Povia afirmou que entre os principais objetivos da $\mathrm{RN} \mathrm{n}^{\circ}$ 18, está a redução do número de supressões de escala sem justificativa. Além disso, ressaltou o que seriam alguns motivos válidos para recusa do transporte de carga. Sejam eles: embarcador não observar preceitos legais ou regulamentares; problemas no acondicionamento dos volumes; comprovada inviabilidade técnica ou econômica; indisponibilidade operacional; inadimplência do usuário perante o transportador; caso fortuito ou força maior; 
Dito isso, é válido o levantamento de algumas reflexões para o sistema brasileiro de transporte marítimo:

- É importante ter frequência? Ou os navios podem não escalar portos onde já anunciaram que atracariam?

- Os órgãos reguladores estão com o objetivo de fazer algo similar às companhias aéreas ou rodoviárias, fixar uma rota e cobrar uma penalidade caso a companhia desmarque a rota. Quão válida seria essa ideia?

- Qual seria o custo dessa atracação para o armador se comparado com as perdas do usuário?

- Será que não estão ambos, donos de navios e usuários, sendo prejudicados por um atraso estrutural do país? 


\section{Considerações finais e recomendações para trabalhos futuros}

Para finalizar, vale ressaltar que é importante, para além desse trabalho, dar continuidade às conclusões inferidas através da análise da base. Trabalhar com uma base descritiva com dados reais nunca antes estudados permite estimular reflexões a respeito das questões levantadas inicialmente e o levantamento de novos questionamentos que podem gerar boas reflexões para transformar o país.

Com relação ao objetivo geral, foi possível obter uma boa descrição e visão integrada do sistema brasileiro do transporte de contêineres. Muitas foram as análises realizadas na dissertação para se tornar possível construir uma visão da oferta de contêineres no transporte marítimo de longo curso no Brasil. No entanto, vale destacar como recomendação para futuros trabalhos, obter uma base de dado que inicialmente contivesse apenas a data do último anúncio da viagem do navio, ou que indicasse qual viagem inicialmente planejada havia sido alterada e realizar o cálculo da oferta levando-se em consideração a rotatividade dos contêineres a cada atracação do navio.

Para dar continuidade ao trabalho, após a finalização do objetivo proposto por essa dissertação, seria muito interessante que fossem estudadas as companhias que realizam cada rota e as mercadorias que elas carregam, assim como as legislações de cada porto brasileiro e dos portos de destino (a taxação de impostos), a infraestrutura dos portos, o desenvolvimento social que a movimentação de cada porto promove, entre outras análises e avaliar como todos esses fatores se relacionam e o impacto disso para o Brasil.

Além disso, seria importante fazer uma nova análise para verificar a efetividade da implementação da Resolução Normativa - $\mathrm{RN} n^{\circ} 18$, entendendo o percentual de navios que deixam de escalar portos que anunciaram que escalariam, para tornar os dados mais precisos.

As caracterizações são importantes na medida em que permitem mapear as dificuldades e apresentar uma visão integrada do sistema que explicita sinergias que muitas vezes as visões particulares camuflam, para que seja possível levantar soluções para os problemas identificados. Estudos e análises fornecem diagnósticos da situação atual que permitem planejamentos pautados em conteúdos sólidos. 
Deve-se ter em mente que mudanças de infraestrutura num país dependem de altos investimentos e precisam de tempo, iniciativa e pensamento a longo prazo para serem realizadas. Mas proporcionalmente à dificuldade da implementação o impacto causado pode ser muito positivo para o desenvolvimento econômico, social e para a eficiência do Brasil.

É incontestável que o crescimento econômico do Brasil e a sua paulatina inserção e consolidação no mercado internacional estão intrinsecamente relacionados ao bom funcionamento do sistema de transportes brasileiro. 


\section{REFERÊNCIAS}

ALIANÇA. [S. 1.], 2020. Disponível em:

https://www.alianca.com.br/alianca/pt/alianca/index.html. Acesso em: 6 abr. 2020.

ANALYTICS, I. (s.d.). Alteryx Designer. Fonte: http://www.itganalytics.com.br/alteryxdesigner.html

ANTAQ. (2017). Anuário Estatístico Aquaviário. São Paulo: Gerência de Estatística e Avaliação de Desempenho da ANTAQ.

ANTAQ. (2017). Sistema de Desempenho Portuário. São Paulo: ANTAQ.

ANTAQ. (20 de 08 de 2018). Portos Organizados. Fonte: Portal da Antaq: http://antaq.gov.br/Portal/pdf/PortosOrganizados.pdf

BAIN \& COMPANY . (2016). Infraestrutura Rodoviária no Brasil: para onde vamos? São Paulo: Bain \& Company.

BARCO, B. L. (1998). A Logística do Contêiner Vazio. São Paulo: Dissertação de Mestado (Engenharia Naval e Oceânica) - Escola Politécnica da Universidade de São PAulo.

BELL, M., \& BICHOU, K. (2008). An analysis into speed and schedule stability for container liner services. Maritime Economics and Logistics.

BOWERSOX, D. J., CLOSS, D. J., \& COOPER, M. B. (2006). Gestão logística de cadeias de suprimentos. Porto Alegre: Bookman.

BRANCHINI, R. M., ARMENTANO, V. A., \& MORABITO, R. (2015). Routing and fleet deployment in liner shipping with spot voyages. Transportation Reserach Part $C$ : Emerging Technologies, 57, 188-205.

BROOKS, M. R., BUTTON, K., \& NIJKAMP, P. (2002). Maritime Transport: classics in transport analysis vol.1. Chelthenham, UK: Edward Elgar.

CEPAL. (15 de 07 de 2017). Perfil Marítimo e Logístico da América Latina e Caribe. Fonte: CEPAL - Nações Unidas: http://perfil.cepal.org/l/es/start.html

CABOTAGEM Log-In Logística. [S. 1.], 2020. Disponível em:

https://www.loginlogistica.com.br/cabotagem. Acesso em: 6 abr. 2020.

CHEAITOU, A., LARBI, R., \& HAMDAN, S. (2018). Liner shipping routing, fleet sizing and speed optimization with application to Asia - Northern Europe-trade. 2018 4th International Conference on Logistics Operations Management (GOL).

CHRISTIANSEN, K., FAGERHOLT, B., \& NYGREEN et al, B. (2013). Ship routing and scheduling in the new millennium. European Jounal of Operational Research. 
CHRISTIANSEN, M., FAGERHOLT, K., \& RONEN, D. (2004). Ship Routing and Scheduling: Status and Perspectives. Transportation Science.

CMA CGM: Freight Shipping Companies. [S. 1.], 2020. Disponível em:

https://www.cmacgm-group.com/en/group/at-a-glance/fleet. Acesso em: 6 abr. 2020.

CNT. (2018). Plano CNT de transporte e logística 2018. Brasília: CNT.

COSTA, G. A. (2006). Modelo de margem de contribuição aplicado ao planejamento de marketing no transporte marítimo regular de contêineres. São Paulo: Escola Politécnica da Universidade de São Paulo.

DRUCKER, P. F. (2003). Inovação e Espírito Empreendedor: prática e princípios. São Paulo: Pioneira.

HAMBURG Sud: Serviço de linhas - Rede Global. [S. 1.], 2020. Disponível em: https://www.hamburgsud-

line.com/liner/pt/liner_services/liner_services_2/liner_services_overview_2.html. Acesso em: 6 abr. 2020.

IBGE. (25 de 11 de 2014). IBGE mapeia a infraestrutura dos transportes no Brasil. Fonte: Agência de Notícias IBGE: https://agenciadenoticias.ibge.gov.br/agencia-sala-deimprensa/2013-agencia-de-noticias/releases/14707-asi-ibge-mapeia-a-infraestruturados-transportes-no-brasil

IPEA. (2009). Brasil em Desenvolvimento: Estado, Planejamento e Políticas Públicas. Brasília: IPEA.

INTERNATIONAL ASSOCIATION OF PORTS AND HARBORS, I. World Container Traffic Data 2017. [s.l.]: [s.n.], 2017.

KJELDSEN, K. (2011). Classification of Ship Routing and Scheduling Problems in Liner Shipping. INFOR: Information Systems and Operational Research.

LAMBERT, D. M., STOCK, J. R., \& VANTINE, J. G. (1998). Administração Estratégica da Logística. São Paulo: Vantine Consultoria.

LAWRENCE, S. A. International Sea Transport: The Years Ahead. Lexington, MA: Lexington Books, 1972.

LEVINSON, M. (2006). The Box. New Jersey, USA: Princeton University Press.

LEVINSON, M. (2006). The Box - How the Shipping Container Made the World Smaller and the World Economy Bigger. New Jersey, USA: Princeton University Press.

LUNA, E. P. (2003). Terminglês: glossário de expressões inglesas de uso corrente no comércio exterior. São Paulo: Aduaneiras.

MASAELI, M., ALUMUR, S., \& BOOKBINDER, J. (2018). Shipment scheduling in hub location problems . Transportation Research Part B: Methodological. 
MAERSK. Maersk line-performing in rough seas. 2013. Disponível em:

<http://files.shareholder.com/downloads/ABEA-3GG91Y/0x0x693342/68e1f253-b6f7-4c9bb22a- f6d31c8625aa/Maersk_Line.pdf>.

MENG, Q., \& WANG, T. (2010). A chance constrained programming model for short-term liner ship fleet planning problems. Maritime Policy and Management.

MENG, Q., S, W., \& ANDERSSON, H. e. (2014). Containership Routing and Scheduling in Liner Shipping: Overview and Future Research Directions. Transportation Science.

MERCOSUL Line. [S. 1.], 2020. Disponível em: http://www.mercosulline.com.br/empresa_navios.php. Acesso em: 6 abr. 2020.

NETTO, J. F. Modelo de Simulação para Dimensionamento da Frota de Contêineres Movimentada por Navios em Rota Dedicada. - Escola Politécnica da Universidade de São Paulo, 2012.

NG, M. (2015). Container vessel fleet deployment for liner shipping with stochastic dependencies in shipping demand. Transportation Research Part B: Methodological.

NG, M., \& LIN, D. (2018). Fleet deployment in liner shipping with incomplete demand information. Transportation Research Part E: Logistics and Transportation Review, 184-189.

NOBRE, M. (2006). A gestão logística do contêiner vazio. São Paulo: Universidade Católica de Santos, Programa de Gestão de Negócios.

NOBRE, M., \& SANTOS, F. R. (2005). O mercado de transporte marítimo: especialização, evolução e os reflexos na logística internacional. SIMPÓSIO DE ENGENHARIA DE PRODUÇÃO (SIMPEP) (p. 12). Bauru: FEB/ Unesp. Fonte: www.simpep.feb.unesp.br

NOTTEBOOM, T. (2004). A carrier`s perspective on container network configuration at sea and on land. Journal of International Logistics and Trade, 65-87.

NOTTEBOOM, T. (2006). The time factor in liner shipping services. Maritime Economics and Logistics, 19-39.

OCDE. (02 de Out de 2005). Development, Organization for Economic Co-operation and. Fonte: www.ocde.org

OFFICE. (s.d.). Excel. Fonte: Suporte Office: https://support.office.com/pt-br/excel

PERAKIS, A., \& JARAMILLO, D. (1991). Fleet deployment optimization for liner shipping part 1. background, problem formulation and solution approaches. Maritime Policy and Management.

ROBINSON, R. (1998). Asian hub/ feeder nets: The dynamics of restructuring. Maritime Policy and Management. 
RONEN, D. (1993). Ship scheduling: the last decade. European Jounal of Operational Research.

RONEN, D. (2002). Cargo ships routing and scheduling: survey of models and problems. Em M. R. BROOKS, K. BUTTON, \& P. NIJKAMP, Maritime transport: classics in transport analysis vol.1. Cheltenham, UK: Edward Elgar.

SANTOS, F. R. (2006). O Marketing dos armadores de longo curso operando navios portacontêineres no Porto de Santos. Dissertação de Mestrado - Universidade Católica de Santos, Programa de Gestão de Negócios, São Paulo.

STOPFORD, M. (2009). Economia Marítima (3a edição ed.). (L. Robles, \& A. C. Casaca, Trads.) São Paulo: Blucher.

TRAN, N., \& HAASIS, H. (2015). Literature survey of network optimization in container liner shipping. Flexible Services an Manufacturing Journal.

UNCTAD. (2009). Review of Maritime Transport. UNITED NATIONS CONFERENCE ON TRADE AND DEVELOPMENT. Nova Iorque e Geneva: United Nations.

UNCTAD. (2010). Review of Maritime Transport. UNITED NATIONS CONFERENCE ON TRADE AND DEVELOPMENT. Nova Iorque e Geneva: United Nations.

UNCTAD. (2011). Review of Maritime Transport. UNITED NATIONS CONFERENCE ON TRADE AND DEVELOPMENT. Nova Iorque e Geneva: United Nations.

UNCTAD. (2012). Review of Maritime Transport. UNITED NATIONS CONFERENCE ON TRADE AND DEVELOPMENT. Geneva e Nova Iorque: United Nations.

UNCTAD. (2013). Review of Maritime Transport. UNITED NATIONS CONFERENCE ON TRADE AND DEVELOPMENT. Nova Iorque e Geneva: United Nations.

UNCTAD. (2014). Review of Maritime Transport. UNITED NATIONS CONFERENCE ON TRADE AND DEVELOPMENT. Nova Iorque e Geneva: United Nations.

UNCTAD. (2016). Review of Maritime Transport. UNITED NATIONS CONFERENCE ON TRADE AND DEVELOPMENT. Nova Iorque e Geneva: United Nations.

UNCTAD. (2017). Review of Maritime Transport. UNITED NATIONS CONFERENCE ON TRADE AND DEVELOPMENT. Nova Iorque e Geneva: United Nations.

UNCTAD. Review of Maritime Transport 2010. In: Review of Maritime Transport. [s.1.]: [s.n.], 2010. ISBN: 0566-7682/978-92-1-112810-9, ISSN: 17496632. Review of Maritime Transport 2012. [s.l.]: [s.n.], 2012. Review of Maritime Transport 2017. [s.1.]: [s.n.], 2017.

VESSELS. (16 de 03 de 2019). Fonte: PORT OF HAMBURG: https://www.hafenhamburg.de/en/vessels 
VESSEL Tracking Ship and Container Tracking. [S. 1.], 2020. Disponível em: http://www.vesseltracking.net/ships?search=zante. Acesso em: 6 abr. 2020.

VIEIRA, G. B. (2003). Transporte Internacional de Cargas. São Paulo: Aduaneiras.

VILHELMSEN, C., LUSBY, R., \& LARSEN, J. (2017). Tramp ship routing and scheduling with voyage separation requirements. OR Spectrum, 913-943.

WALLER, S., SCHOFER, J., \& ZILIASKOPOULOS, A. (2001). Evaluation with Traffic Assignment Under Demand Uncertainty. Transportation Research Record. 


\section{APÊNDICES}

\section{APÊNDICE A - CARACTERÍSTICAS DOS NAVIOS PORTA-CONTÊINERES QUE PASSARAM PELA COSTA BRASILEIRA}

Tabela 32 - Navios porta-contêineres que passaram pela costa brasileira, seu respectivo ano de construção e sua capacidade

\begin{tabular}{|c|c|c|c|}
\hline Nome Navio & $\begin{array}{l}\text { Ano do } \\
\text { navio }\end{array}$ & $\begin{array}{l}\text { Capac. } \\
\text { (TEUs) }\end{array}$ & $\begin{array}{l}\text { Idade } \\
\text { (anos) }\end{array}$ \\
\hline Allegoria & 2006 & 5527 & 12 \\
\hline Amazonia & 1991 & 1050 & 27 \\
\hline Anthea Y & 2001 & 1740 & 17 \\
\hline Antofagasta Express & 2015 & 3500 & 3 \\
\hline Arica Express & 2007 & 2797 & 11 \\
\hline Bea Schulte & 2010 & 4616 & 8 \\
\hline Bf Caroda & 2004 & 862 & 14 \\
\hline Buxharmony & 2007 & 2702 & 11 \\
\hline Cap Cortes & 2013 & 3820 & 5 \\
\hline Cap San Antonio & 2014 & 9814 & 4 \\
\hline Cap San Artemissio & 2014 & 9814 & 4 \\
\hline Cap San Augustin & 2013 & 9814 & 5 \\
\hline Cap San Juan & 2015 & 10600 & 3 \\
\hline Cap San Lazaro & 2015 & 10950 & 3 \\
\hline Cap San Lorenzo & 2013 & 9814 & 5 \\
\hline Cap San Maleas & 2014 & 10500 & 4 \\
\hline Cap San Marco & 2013 & 9814 & 5 \\
\hline Cap San Nicolas & 2013 & 9814 & 5 \\
\hline Cap San Raphael & 2014 & 9814 & 4 \\
\hline Cap San Vincent & 2015 & 10600 & 3 \\
\hline Ccni Andes & 2015 & 9030 & 3 \\
\hline Ccni Angol & 2015 & 9030 & 3 \\
\hline Cezanne & 2015 & 9971 & 3 \\
\hline Chacabuco & 2006 & 5527 & 12 \\
\hline Cma Cgm Brazil & 2015 & 2350 & 3 \\
\hline Cma Cgm Cayenne & 2015 & 2140 & 3 \\
\hline Cma Cgm Congo & 2015 & 9448 & 3 \\
\hline Cma Cgm Ganges & 2015 & 9956 & 3 \\
\hline Cma Cgm Marseille & 2015 & 2140 & 3 \\
\hline Cma Cgm Mekong & 2015 & 9956 & 3 \\
\hline Cma Cgm Saint Laurent & 2015 & 2140 & 3 \\
\hline Conti Darwin & 1999 & 6078 & 19 \\
\hline Cosco Shipping Volga & 2017 & 9092 & 1 \\
\hline Cs Setubal & 1997 & 1122 & 21 \\
\hline Csav Toconao & 2013 & 9000 & 5 \\
\hline Dali & 2015 & 10000 & 3 \\
\hline
\end{tabular}

\begin{tabular}{|c|c|c|c|}
\hline Durande & 2003 & 1740 & 15 \\
\hline E.R. Berlin & 2000 & 5762 & 18 \\
\hline E.R. Canada & 2001 & 5762 & 17 \\
\hline E.R. Denmark & 2002 & 5762 & 16 \\
\hline E.R. London & 2000 & 5514 & 18 \\
\hline E.R. Seoul & 2000 & 5514 & 18 \\
\hline E.R. Sweden & 2002 & 5762 & 16 \\
\hline E.R. Tianan & 2005 & 8204 & 13 \\
\hline Ebba Maersk & 2007 & 15500 & 11 \\
\hline Eleonora Maersk & 2007 & 15550 & 11 \\
\hline Elly Maersk & 2007 & 15500 & 11 \\
\hline Emma Maersk & 2006 & 15500 & 12 \\
\hline Estelle Maersk & 2006 & 15550 & 12 \\
\hline Eugen Maersk & 2008 & 15550 & 10 \\
\hline Express Brazil & 2010 & 3510 & 8 \\
\hline Express France & 2010 & 3510 & 8 \\
\hline Gerhard Schulte & 2006 & 3534 & 12 \\
\hline Helga & 2008 & 1700 & 10 \\
\hline Hs Berlioz & 2007 & 3568 & 11 \\
\hline Hs Rossini & 2012 & 3568 & 6 \\
\hline Jpo Leo & 2005 & 3104 & 13 \\
\hline Jpo Scorpius & 2007 & 2572 & 11 \\
\hline Lutetia & 2005 & 3104 & 13 \\
\hline Maersk Genoa & 2016 & 10100 & 2 \\
\hline Maersk Gibraltar & 2016 & 10100 & 2 \\
\hline Maersk Guayaquil & 2015 & 10100 & 3 \\
\hline Maersk Kobe & 2000 & 6250 & 18 \\
\hline Maersk Kolkata & 2003 & 6246 & 15 \\
\hline Maersk Laberinto & 2012 & 8700 & 6 \\
\hline Maersk Labrea & 2013 & 8700 & 5 \\
\hline Maersk Laguna & 2011 & 7450 & 7 \\
\hline Maersk Lamanai & 2013 & 8700 & 5 \\
\hline Maersk Lanco & 2013 & 8700 & 5 \\
\hline Maersk Leon & 2012 & 8700 & 6 \\
\hline Maersk Leticia & 2011 & 7450 & 7 \\
\hline Maersk Lima & 2011 & 7564 & 7 \\
\hline Maersk Lins & 2012 & 8700 & 6 \\
\hline Maersk Lirquen & 2011 & 7450 & 7 \\
\hline
\end{tabular}




\begin{tabular}{|c|c|c|c|}
\hline Maersk Lota & 2012 & 8700 & 6 \\
\hline Maersk Saltoro & 2015 & 9962 & 3 \\
\hline Maersk Sarat & 2015 & 9443 & 3 \\
\hline Maersk Shams & 2015 & 10000 & 3 \\
\hline Maersk Sirac & 2015 & 7450 & 3 \\
\hline Maersk Stadelhorn & 2015 & 9962 & 3 \\
\hline March & 2004 & 5576 & 14 \\
\hline Marfret Guyane & 2007 & 1691 & 11 \\
\hline Marfret Marajo & 2009 & 1691 & 9 \\
\hline Max Loyalty & 2006 & 868 & 12 \\
\hline Mol Anchorage & 2013 & 8762 & 5 \\
\hline Mol Genesis & 2012 & 5605 & 6 \\
\hline Mol Londrina & 2012 & 8700 & 6 \\
\hline Mol Paramount & 2005 & 6350 & 13 \\
\hline Monte Tamaro & 2007 & 4000 & 11 \\
\hline Msc Abidjan & 2013 & 8772 & 5 \\
\hline Msc Agadir & 2012 & 8962 & 6 \\
\hline Msc Ajaccio & 2013 & 9400 & 5 \\
\hline Msc Alessia & 2001 & 6732 & 17 \\
\hline Msc Alicante & 2011 & 5550 & 7 \\
\hline Msc Amalfi & 2014 & 9400 & 4 \\
\hline Msc Amsterdam & 2015 & 16652 & 3 \\
\hline Msc Anna & 2016 & 17273 & 2 \\
\hline Msc Arica & 2012 & 8762 & 6 \\
\hline Msc Azov & 2014 & 9400 & 4 \\
\hline Msc Barbara & 2002 & 6402 & 16 \\
\hline Msc Barcelona & 2011 & 5550 & 7 \\
\hline Msc Cadiz & 2011 & 4390 & 7 \\
\hline Msc Carolina & 2005 & 5606 & 13 \\
\hline Msc Coruna & 2011 & 5550 & 7 \\
\hline Msc Eloane & 2016 & 19462 & 2 \\
\hline Msc Emanuela & 2010 & 13798 & 8 \\
\hline Msc Erica & 2016 & 19437 & 2 \\
\hline Msc Fiammetta & 2008 & 5770 & 10 \\
\hline Msc Gaia & 2010 & 14000 & 8 \\
\hline Msc Geneva & 2006 & 4860 & 12 \\
\hline Msc Hamburg & 2015 & 16652 & 3 \\
\hline Msc Ilona & 2001 & 6732 & 17 \\
\hline Msc Istanbul & 2015 & 16652 & 3 \\
\hline Msc Jeongmin & 2016 & 9400 & 2 \\
\hline Msc Judith & 2006 & 8034 & 12 \\
\hline Msc Julie & 2015 & 880 & 3 \\
\hline Msc Kalamata & 2003 & 6416 & 15 \\
\hline Msc Katyayni & 1996 & 5711 & 22 \\
\hline Msc Kingston & 2003 & 6246 & 15 \\
\hline Msc Krystal & 2008 & 5762 & 10 \\
\hline Msc Laura & 2002 & 6732 & 16 \\
\hline
\end{tabular}

\begin{tabular}{|c|c|c|c|}
\hline Msc Letizia & 2015 & 8800 & 3 \\
\hline Msc Lily & 2015 & 8800 & 3 \\
\hline Msc Ludovica & 2003 & 6732 & 15 \\
\hline Msc Luisa & 2002 & 6732 & 16 \\
\hline Msc Madrid & 2011 & 5550 & 7 \\
\hline Msc Margarita & 2002 & 5762 & 16 \\
\hline Msc Marianna & 2002 & 6730 & 16 \\
\hline Msc Marina & 2003 & 6402 & 15 \\
\hline Msc Marta & 2005 & 5599 & 13 \\
\hline Msc Maureen & 2003 & 6732 & 15 \\
\hline Msc Meline & 2015 & 8800 & 3 \\
\hline Msc Michaela & 2002 & 6402 & 16 \\
\hline Msc Mirjam & 2016 & 19200 & 2 \\
\hline Msc Naomi & 2015 & 8800 & 3 \\
\hline Msc Oriane & 2008 & 5782 & 10 \\
\hline Msc Sara Elena & 2015 & 8800 & 3 \\
\hline Msc Soraya & 2008 & 5800 & 10 \\
\hline Msc Vanessa & 2003 & 6732 & 15 \\
\hline Msc Venice & 2016 & 15908 & 2 \\
\hline Msc Vidhi & 2001 & 5514 & 17 \\
\hline Msc Vigo & 2012 & 5550 & 6 \\
\hline Msc Vita & 2015 & 8800 & 3 \\
\hline Nordamelia & 2017 & 2500 & 1 \\
\hline Nordic Beijing & 2013 & 3421 & 5 \\
\hline Nordic Hong Kong & 2013 & 3421 & 5 \\
\hline Nordic Macau & 2013 & 3421 & 5 \\
\hline Nordic Stralsund & 2013 & 3421 & 5 \\
\hline Northern Juvenile & 2009 & 8400 & 9 \\
\hline Northern Majestic & 2004 & 6750 & 14 \\
\hline Ocean Blue & 2017 & 0 & 1 \\
\hline Pandora & 2008 & 2702 & 10 \\
\hline Pantanal & 2004 & 611 & 14 \\
\hline Polonia & 2003 & 3091 & 15 \\
\hline Rhodos & 2013 & 6900 & 5 \\
\hline Rio Barrow & 2001 & 5551 & 17 \\
\hline Rio De Janeiro & 2008 & 5905 & 10 \\
\hline Rio Negro & 2008 & 5905 & 10 \\
\hline Rr Europa & 2002 & 2466 & 16 \\
\hline San Antonio Express & 2008 & 1841 & 10 \\
\hline San Fernando & 2015 & 8714 & 3 \\
\hline San Vicente & 2014 & 9034 & 4 \\
\hline San Vicente Express & 2014 & 3500 & 4 \\
\hline Seamax Rowayton & 2015 & 9443 & 3 \\
\hline Skyros & 2014 & 9000 & 4 \\
\hline Switzerland & 2016 & 9000 & 2 \\
\hline Tempanos & 2011 & 8000 & 7 \\
\hline Tubul & 2011 & 8000 & 7 \\
\hline
\end{tabular}




\begin{tabular}{llll}
\hline Valence & 2013 & 8800 & 5 \\
\hline Valiant & 2013 & 8800 & 5 \\
\hline Valor & 2013 & 8800 & 5 \\
\hline Value & 2013 & 8800 & 5 \\
\hline Vilano & 2006 & 2742 & 12 \\
\hline Widukind & 2006 & 3100 & 12 \\
\hline Wms Harlingen & 2007 & 698 & 11 \\
\hline X-Press Mulhacen & 2008 & 767 & 10 \\
\hline Zante & 2002 & 493 & 16 \\
\hline
\end{tabular}

Fonte: autoria própria 
APÊNDICE B - \# DE VIAGENS, TEMPO MÉDIO DE VIAGEM NO BRASIL E TEMPO MÉDIO NO EXTERIOR DOS NAVIOS RECORRENTES QUE PERCORRERAM A COSTA BRASILEIRA

Tabela 33 - Estatísticas dos navios como tempo de rota médio no Brasil e número de viagens realizadas

\begin{tabular}{|c|c|c|c|c|c|c|c|}
\hline \multirow[t]{2}{*}{ Navio } & \multirow{2}{*}{$\begin{array}{l}\text { \# de } \\
\text { viagens }\end{array}$} & \multirow{2}{*}{$\begin{array}{l}\text { Tempo } \\
\text { médio } \\
\text { no Brasil }\end{array}$} & \multirow{2}{*}{$\begin{array}{l}\text { Tempo } \\
\text { médio no } \\
\text { exterior }\end{array}$} & MAERSK LIMA & 6,0 & 24,2 & 26,0 \\
\hline & & & & MAERSK LINS & 5,0 & 36,4 & 29,6 \\
\hline CAP SAN ANTONIO & 10,0 & 19,3 & 15,9 & MAERSK LOTA & 7,0 & 24,7 & 27,3 \\
\hline CAP SAN & 13,0 & 15,4 & 12,1 & E. R. LONDON & 7,0 & 13,1 & 31,0 \\
\hline ARTEMISSIO & & & & MOL GENESIS & 8,0 & 12,3 & 29,9 \\
\hline $\begin{array}{l}\text { CAP SAN } \\
\text { AUGUSTIN }\end{array}$ & 11,0 & 18,4 & 14,4 & MSC BARBARA & 3,0 & 13,3 & 24,0 \\
\hline CAP SAN LORENZO & 12,0 & 17,0 & 13,3 & MSC FIAMMETTA & 3,0 & 12,3 & 24,7 \\
\hline CAP SAN MALEAS & 10,0 & 19,3 & 15,8 & MSC KATYAYNI & 6,0 & 12,8 & 29,8 \\
\hline CAP SAN MARCO & 9,0 & 23,4 & 14,3 & MSC KRYSTAL & 7,0 & 14,3 & 29,5 \\
\hline CAP SAN NICOLAS & 9,0 & 20,1 & 14,7 & MSC MARIANNA & 4,0 & 10,3 & 23,7 \\
\hline CAP SAN RAPHAEL & 9,0 & 20,2 & 14,6 & MSC MARINA & 6,0 & 4,6 & 20,4 \\
\hline CEZANNE & 4,0 & 40,0 & 28,0 & MSC ORIANE & 10,0 & 13,4 & 18,4 \\
\hline MAERSK & 7,0 & 21,6 & 26,1 & MSC VIDHI & 13,0 & 6,3 & 19,4 \\
\hline LABERINTO & & & & NORTHERN & 3,0 & 14,0 & 18,0 \\
\hline MAERSK LABREA & 7,0 & 27,3 & 23,9 & MAJESTIC & & & \\
\hline MAERSK LAMANAI & 7,0 & 30,7 & 21,3 & RIO BARROW & 8,0 & 13,3 & 30,6 \\
\hline MAERSK LANCO & 7,0 & 29,4 & 22,7 & BF CARODA & 9,0 & 10,4 & 3,0 \\
\hline MAERSK LEON & 7,0 & 24,9 & 22,1 & HELGA & 20,0 & 7,5 & 2,5 \\
\hline
\end{tabular}

\begin{tabular}{|c|c|c|c|}
\hline MSC JULIE & 5,0 & 9,2 & 26,4 \\
\hline MSC MELINE & 10,0 & 6,9 & 28,1 \\
\hline WMS HARLINGEN & 2,0 & 9,0 & 3,0 \\
\hline $\begin{array}{l}\text { X-PRESS } \\
\text { MULHACEN }\end{array}$ & 23,0 & 10,6 & 5,0 \\
\hline MAX LOYALTY & 4,0 & 9,0 & 4,0 \\
\hline MSC AGADIR & 5,0 & 8,8 & 27,2 \\
\hline MSC AJACCIO & 10,0 & 7,6 & 26,9 \\
\hline MSC AMALFI & 8,0 & 11,6 & 31,1 \\
\hline MSC ARICA & 10,0 & 7,3 & 27,9 \\
\hline MSC AZOV & 3,0 & 7,3 & 23,7 \\
\hline MSC LETIZIA & 4,0 & 11,7 & 20,3 \\
\hline MSC ALICANTE & 10,0 & 19,2 & 15,4 \\
\hline MSC BARCELONA & 8,0 & 25,8 & 15,0 \\
\hline MSC CADIZ & 9,0 & 23,3 & 12,1 \\
\hline MSC CORUNA & 8,0 & 21,5 & 19,1 \\
\hline MSC MADRID & 9,0 & 21,6 & 18,9 \\
\hline MSC MARTA & 10,0 & 15,3 & 18,2 \\
\hline
\end{tabular}




\begin{tabular}{lccc}
\hline MSC VIGO & 10,0 & 16,4 & 14,9 \\
\hline RHODOS & 5,0 & 21,2 & 12,4 \\
\hline RIO DE JANEIRO & 7,0 & 28,4 & 21,3 \\
\hline RIO NEGRO & 7,0 & 22,0 & 29,0 \\
\hline AMAZONIA & 24,0 & 6,0 & 2,8 \\
\hline
\end{tabular}

\begin{tabular}{llll}
\hline PANTANAL & 30,0 & 4,0 & 3,2 \\
\hline CMA CGM BRAZIL & 9,0 & 2,0 & 42,0 \\
\hline $\begin{array}{l}\text { CMA CGM } \\
\text { CAYENNE }\end{array}$ & 11,0 & 2,0 & 30,9 \\
\hline $\begin{array}{l}\text { CMA CGM } \\
\text { MARSEILLE }\end{array}$ & 9,0 & 2,0 & 37,4 \\
\hline
\end{tabular}

\begin{tabular}{lccc}
\hline $\begin{array}{l}\text { CMA CGM SAINT } \\
\text { LAURENT }\end{array}$ & 8,0 & 2,0 & 36,9 \\
\hline MARFRET GUYANE & 10,0 & 2,0 & 29,5 \\
\hline MARFRET MARAJO & 8,0 & 2,0 & 36,9 \\
\hline
\end{tabular}

Fonte: autoria própria 


\section{APÊNDICE C - QUANTIDADE DE VEZES QUE OS NAVIOS ANALISADOS ANUNCIARAM QUE ATRACARIAM NOS PORTOS}

Tabela 34 - Quantidade de vezes que os navios da Cap da rota A anunciaram que atracariam nos portos

\begin{tabular}{|c|c|c|c|c|c|c|c|c|c|}
\hline Nome Navio & $\begin{array}{l}\text { CAP SAN } \\
\text { ANTONIO }\end{array}$ & $\begin{array}{l}\text { CAP SAN } \\
\text { ARTEMISSIO }\end{array}$ & $\begin{array}{l}\text { CAP SAN } \\
\text { AUGUSTIN }\end{array}$ & $\begin{array}{l}\text { CAP SAN } \\
\text { LORENZO }\end{array}$ & $\begin{array}{l}\text { CAP SAN } \\
\text { MALEAS }\end{array}$ & $\begin{array}{l}\text { CAP SAN } \\
\text { MARCO }\end{array}$ & $\begin{array}{l}\text { CAP SAN } \\
\text { NICOLAS }\end{array}$ & $\begin{array}{l}\text { CAP SAN } \\
\text { RAPHAEL }\end{array}$ & CEZANNE \\
\hline Aqaba & & & & & & & & & 2 \\
\hline Algeciras & 4 & 5 & 3 & 4 & 3 & 3 & 3 & 3 & 17 \\
\hline Antwerpen & 21 & 19 & 22 & 19 & 23 & 23 & 24 & 22 & 15 \\
\hline As_Suways & & & & & & & & & 3 \\
\hline Bremerhaven & 4 & 5 & 3 & 4 & 3 & 3 & 3 & 2 & 16 \\
\hline Buenos_Aires & 25 & 18 & 25 & 21 & 24 & 21 & 21 & 19 & 4 \\
\hline Felixstowe & & & & & & & & & 4 \\
\hline Genova & & & & & & & & & 2 \\
\hline
\end{tabular}

\begin{tabular}{|c|c|c|c|c|c|c|c|c|c|}
\hline Hamburg & 20 & 22 & 22 & 19 & 22 & 23 & 24 & 22 & \\
\hline Itajai & 5 & 6 & 4 & 5 & 3 & 3 & 3 & 3 & 14 \\
\hline Itapoa & 24 & 22 & 26 & 22 & 22 & 21 & 22 & 19 & \\
\hline Jebel_Ali & & & & & & & & & 4 \\
\hline Jeddah & & & & & & & & & 5 \\
\hline Le_Havre & 21 & 19 & 22 & 19 & 23 & 23 & 24 & 22 & 5 \\
\hline London & 7 & 7 & 8 & 7 & 7 & 8 & 9 & 9 & 3 \\
\hline London_Gateway_Port & 20 & 20 & 22 & 19 & 20 & 23 & 24 & 22 & 7 \\
\hline Montevideo & 25 & 18 & 25 & 21 & 24 & 21 & 18 & 19 & 4 \\
\hline Mundra & & & & & & & & & 3 \\
\hline Nhava_Sheva & & & & & & & & & 4 \\
\hline Paranagua & 25 & 21 & 26 & 21 & 23 & 23 & 22 & 19 & 14 \\
\hline Pecem & 4 & 6 & 3 & 5 & 3 & 3 & 3 & 3 & 4 \\
\hline Rio_Grande & 25 & 21 & 25 & 20 & 20 & 21 & 21 & 19 & 8 \\
\hline Rotterdam & 22 & 24 & 24 & 20 & 21 & 23 & 25 & 23 & 16 \\
\hline Salalah & & & & & & & & & 2 \\
\hline Santos & 25 & 21 & 26 & 21 & 23 & 23 & 22 & 20 & 13 \\
\hline Tanger_Med & 9 & 9 & 10 & 11 & 9 & 8 & 11 & 11 & 1 \\
\hline Tangier & 14 & 14 & 16 & 14 & 14 & 14 & 14 & 13 & 2 \\
\hline Tanjung_Priok & 6 & 5 & 6 & 7 & 6 & 6 & 6 & 5 & 2 \\
\hline
\end{tabular}


Tabela 35 - Quantidade de vezes que os navios Maersk da rota A anunciaram que atracariam nos portos

\begin{tabular}{|c|c|c|c|c|c|c|c|c|}
\hline Nome Navio & $\begin{array}{l}\text { MAERSK } \\
\text { LABERINTO }\end{array}$ & $\begin{array}{l}\text { MAERSK } \\
\text { LABREA }\end{array}$ & $\begin{array}{l}\text { MAERSK } \\
\text { LAMANAI }\end{array}$ & $\begin{array}{l}\text { MAERSK } \\
\text { LANCO }\end{array}$ & $\begin{array}{l}\text { MAERSK } \\
\text { LEON }\end{array}$ & $\begin{array}{l}\text { MAERSK } \\
\text { LIMA }\end{array}$ & $\begin{array}{l}\text { MAERSK } \\
\text { LINS }\end{array}$ & $\begin{array}{l}\text { MAERSK } \\
\text { LOTA }\end{array}$ \\
\hline Antwerpen & 21 & 20 & 22 & 22 & 22 & 22 & 19 & 21 \\
\hline Bremerhaven & 21 & 21 & 22 & 25 & 23 & 23 & 21 & 22 \\
\hline Buenos_Aires & 9 & 9 & 9 & 9 & 10 & 8 & 9 & 10 \\
\hline Cape_Town & & & & 2 & & & & \\
\hline Hamburg & 3 & 2 & 3 & 2 & 2 & 2 & 3 & 2 \\
\hline Itaguai & 1 & 1 & 1 & 1 & & & & 1 \\
\hline Itajai & 21 & 24 & 22 & 25 & 23 & 17 & 21 & 22 \\
\hline Itapoa & 2 & 1 & 4 & 1 & 1 & 1 & 1 & 2 \\
\hline Le_Havre & 12 & 10 & 12 & 9 & 12 & 13 & 14 & 9 \\
\hline London & 8 & 6 & 8 & 5 & 10 & 7 & 6 & 9 \\
\hline Paranagua & 22 & 24 & 24 & 24 & 23 & 18 & 21 & 21 \\
\hline Pecem & 7 & 6 & 10 & 6 & 7 & 6 & 5 & 6 \\
\hline Port_Elizabeth & & & & 2 & & & & \\
\hline Port_of_Itaguai & 1 & & & & & & & \\
\hline Rio_Grande & 16 & 15 & 18 & 17 & 17 & 14 & 15 & 21 \\
\hline Rotterdam & 21 & 19 & 22 & 26 & 23 & 23 & 19 & 22 \\
\hline Santos & 22 & 25 & 27 & 25 & 23 & 19 & 21 & 25 \\
\hline Tanger_Med & 1 & & & 1 & & & & \\
\hline Tangier & & 1 & & 1 & & & & \\
\hline Tanjung_Priok & 2 & 1 & 2 & 1 & 2 & 1 & 1 & 1 \\
\hline Tilbury & 5 & 5 & 6 & 5 & 4 & 7 & 5 & 5 \\
\hline Valencia & 1 & & & & & & & \\
\hline
\end{tabular}

Fonte: autoria própria 
Tabela 36 - Quantidade de vezes que os navios MSC da rota B anunciaram que atracariam nos portos

\begin{tabular}{|c|c|c|c|c|c|c|c|c|}
\hline Nome Navio & $\begin{array}{l}\text { MSC } \\
\text { BARBARA }\end{array}$ & $\begin{array}{l}\text { MSC } \\
\text { FIAMMETTA }\end{array}$ & $\begin{array}{l}\text { MSC } \\
\text { KATYAYNI }\end{array}$ & $\begin{array}{l}\text { MSC } \\
\text { KRYSTAL }\end{array}$ & $\begin{array}{l}\text { MSC } \\
\text { MARIANNA }\end{array}$ & $\begin{array}{l}\text { MSC } \\
\text { MARINA }\end{array}$ & $\begin{array}{l}\text { MSC } \\
\text { ORIANE }\end{array}$ & $\begin{array}{l}\text { MSC } \\
\text { VIDHI }\end{array}$ \\
\hline Alexandria & & & & 2 & & & & \\
\hline Algeciras & & & & 2 & & & & \\
\hline Antwerpen & 36 & 25 & 28 & 39 & 12 & 31 & 44 & 51 \\
\hline Ashdod & & & & & & & 14 & \\
\hline Bremerhaven & 37 & 25 & 29 & 38 & 8 & 31 & 45 & 32 \\
\hline Charleston & & & & & 24 & & & \\
\hline Dakar & & & 1 & & & & & \\
\hline Felixstowe & 12 & 8 & & 4 & 24 & & 18 & \\
\hline Freeport_Grand_Bahama & & & 25 & & & & & \\
\hline Genova & & & & 2 & & & & \\
\hline Gioia_Tauro & & & & 2 & & & & \\
\hline Haifa & & & & & & & & 14 \\
\hline Hamburg & 8 & 25 & 30 & 38 & 8 & 7 & 43 & 44 \\
\hline Houston & & & & & 1 & & & \\
\hline La_Spezia & & & & 2 & & & & \\
\hline Le_Havre & 36 & 25 & 28 & 36 & 8 & 31 & 45 & 47 \\
\hline \multicolumn{9}{|l|}{ Le_Port } \\
\hline Lisboa & 6 & 6 & 13 & 26 & 7 & 5 & 30 & 24 \\
\hline Livorno & & & & 2 & & & & \\
\hline London_Gateway_Port & 2 & & & & & & 2 & \\
\hline Mersin & & & & & 2 & & & \\
\hline Mobile & & & & & & 25 & & \\
\hline Napoli & & & & & 2 & & & 10 \\
\hline Navegantes & 8 & 7 & 20 & 26 & 8 & 7 & 38 & 32 \\
\hline New_Orleans & & & & & 26 & & & \\
\hline Paranagua & 8 & 9 & 20 & 28 & 8 & 4 & 38 & 34 \\
\hline Rio_de_Janeiro & 8 & 8 & 20 & 29 & 7 & 4 & 39 & 34 \\
\hline Rotterdam & 8 & 11 & 18 & 38 & 12 & 31 & 45 & 45 \\
\hline Salvador & 8 & 7 & 18 & 29 & 7 & 7 & 34 & 26 \\
\hline Santos & 8 & 8 & 20 & 28 & 8 & 7 & 40 & 35 \\
\hline Savannah & & & & & 18 & & & \\
\hline
\end{tabular}


Valencia

Veracruz

Fonte: autoria própria 
Tabela 37 - Quantidade de vezes que os outros navios da rota 2 anunciaram que atracariam nos portos

\begin{tabular}{|c|c|c|c|c|}
\hline Nome Navio & E.R. LONDON & MOL GENESIS & NORTHERN MAJESTIC & RIO BARROW \\
\hline Altamira & 5 & & & \\
\hline Antwerpen & 40 & 37 & 10 & 35 \\
\hline Baltimore & & 23 & & \\
\hline Bremerhaven & 38 & 31 & 10 & 33 \\
\hline Colombo & 2 & & & \\
\hline Felixstowe & & 28 & & \\
\hline Fos_sur_Mer & 3 & & & \\
\hline Gioia_Tauro & 3 & & & \\
\hline Hamburg & 40 & 28 & 8 & 27 \\
\hline Houston & 5 & & & \\
\hline King_Abdullah_City & 2 & & & \\
\hline La_Spezia & 3 & & & \\
\hline Le_Havre & 37 & 41 & 10 & 30 \\
\hline Le_Port & 1 & & & \\
\hline Lisboa & 27 & 25 & 6 & 26 \\
\hline London_Gateway_Port & 5 & & & \\
\hline Melbourne & 3 & & & \\
\hline Mobile & & 5 & & \\
\hline Napoli & & 3 & & \\
\hline Navegantes & 30 & 27 & 9 & 30 \\
\hline New_Orleans & 5 & & & \\
\hline New_York & & 14 & & \\
\hline Newark & & 13 & & \\
\hline Norfolk & & 23 & & \\
\hline Paranagua & 30 & 27 & 9 & 28 \\
\hline Port_de_Pointe_des_Galets & 2 & & & \\
\hline Port_Louis & 3 & & & \\
\hline Rio_de_Janeiro & 30 & 27 & 9 & 31 \\
\hline Rotterdam & 40 & 28 & 10 & 33 \\
\hline Salvador & 27 & 24 & 9 & 27 \\
\hline Santos & 31 & 26 & 10 & 31 \\
\hline Savannah & & 6 & & \\
\hline Sines & 28 & 25 & 8 & 26 \\
\hline Southampton & 5 & & & \\
\hline Sydney & & 3 & & \\
\hline
\end{tabular}


Wilmington

5

Fonte: autoria própria 
Tabela 38 - Quantidade de vezes que os navios da rota $C$ anunciaram que atracariam nos portos

\begin{tabular}{|c|c|c|c|c|c|c|}
\hline Nome Navio & BF CARODA & HELGA & MSC JULIE & MSC MELINE & WMS HARLINGEN & X-PRESS MULHACEN \\
\hline Agadir & 6 & & & & & \\
\hline Algeciras & 19 & 35 & 9 & 12 & 7 & 44 \\
\hline Ancona & & 6 & & & 6 & \\
\hline Balboa & & & 8 & & & \\
\hline Bar & & 6 & & & & \\
\hline Barcadera & & 3 & & & & \\
\hline Barcelona & 6 & & & & & \\
\hline Bilbao & & 5 & & & & \\
\hline Casablanca & 7 & 2 & & & & 3 \\
\hline Catania & & 1 & & & 14 & \\
\hline Civitavecchia & & & 8 & & & \\
\hline Cristobal & & & 8 & & & \\
\hline Durres & & 5 & & & 1 & \\
\hline Gioia_Tauro & & & 8 & & & \\
\hline Halifax & & 5 & & & & \\
\hline Itajai & 9 & 21 & 8 & 14 & 2 & 24 \\
\hline Itapoa & 9 & 21 & 9 & 14 & 2 & 24 \\
\hline Koper & & 1 & & & 6 & \\
\hline La_Spezia & & & 8 & & & \\
\hline Las_Palmas_de_Gran_Canaria & 17 & 33 & 7 & 10 & & 36 \\
\hline Long_Beach & & & 7 & & & \\
\hline Malta & & 1 & & & 9 & \\
\hline Malta_Freeport_Distripark & & 13 & & & 10 & \\
\hline Mariel & & 5 & & & & \\
\hline Marseille & 6 & & & & & \\
\hline Moa & & 4 & & & & \\
\hline Napoli & & & & & 12 & \\
\hline Navegantes & 9 & 21 & 8 & 14 & 2 & 25 \\
\hline Nuevitas & & 3 & & & & \\
\hline Oakland & & & 7 & & & \\
\hline Paranagua & 9 & 21 & 9 & 14 & 2 & 24 \\
\hline Port_Vendres & 4 & & & & & \\
\hline Ravenna & & 2 & & & 5 & \\
\hline Rijeka & & 1 & & & 6 & \\
\hline Rotterdam & & 6 & & & & \\
\hline
\end{tabular}




\begin{tabular}{|c|c|c|c|c|c|c|}
\hline Salerno & & & & & 16 & \\
\hline Salvador & 9 & 21 & 9 & 14 & 2 & 25 \\
\hline Santa_Cruz_de_Tenerife & 11 & 12 & & & & 18 \\
\hline Santos & 9 & 21 & 8 & 14 & 2 & 25 \\
\hline Sines & & & 8 & & & \\
\hline Tanger_Med & 1 & & & & & 5 \\
\hline Tangier & & & 3 & 3 & & \\
\hline Tanjung_Priok & 10 & 21 & 5 & 8 & 1 & 25 \\
\hline Vado_Ligure & & & & & 7 & \\
\hline Valencia & 15 & 21 & 18 & 12 & & 29 \\
\hline Vancouver & & & 7 & & & \\
\hline Venezia & & & & & 7 & \\
\hline
\end{tabular}




\begin{tabular}{|c|c|c|c|c|c|c|c|}
\hline Nome Navio & $\begin{array}{l}\text { MAX } \\
\text { LOYALTY }\end{array}$ & $\begin{array}{l}\text { MSC } \\
\text { AGADIR }\end{array}$ & $\begin{array}{l}\text { MSC } \\
\text { AJACCIO }\end{array}$ & $\begin{array}{l}\text { MSC } \\
\text { AMALFI }\end{array}$ & $\begin{array}{l}\text { MSC } \\
\text { ARICA }\end{array}$ & $\begin{array}{l}\text { MSC } \\
\text { AZOV }\end{array}$ & $\begin{array}{l}\text { MSC } \\
\text { LETIZIA }\end{array}$ \\
\hline Algeciras & 10 & 7 & 17 & 14 & 16 & 6 & 8 \\
\hline Antwerpen & & 4 & & & 1 & & \\
\hline Balboa & & & & & & & 7 \\
\hline Bilbao & 10 & & & & & & \\
\hline Civitavecchia & & & & & & & 7 \\
\hline Cristobal & & & & & & & 7 \\
\hline Gijon & 7 & & & & & & \\
\hline Gioia_Tauro & & & & & & & 7 \\
\hline Hamburg & & 4 & & & 1 & & \\
\hline Hong_Kong & & & & & 1 & & \\
\hline Itajai & 4 & 8 & 16 & 13 & 15 & 5 & 7 \\
\hline Itapoa & 4 & 8 & 16 & 11 & 15 & 5 & 7 \\
\hline Jebel_Ali & & & & & 1 & & \\
\hline La_Spezia & & & & & & & 7 \\
\hline Las_Palmas_de_Gran_Canaria & 10 & 7 & 15 & 11 & 14 & 6 & 4 \\
\hline Le_Havre & 8 & 4 & & & 1 & & \\
\hline Leixoes & 16 & & & & & & \\
\hline Lisboa & 4 & & & & & & \\
\hline London_Gateway_Port & & 4 & & & & & \\
\hline Long_Beach & & & & & & & 8 \\
\hline Navegantes & 4 & 7 & 16 & 11 & 15 & 5 & 7 \\
\hline Oakland & & & & & & & 8 \\
\hline Paranagua & 4 & 8 & 16 & 11 & 15 & 5 & 7 \\
\hline Ploce & 1 & & & & & & \\
\hline Rotterdam & 27 & 4 & & & 1 & & \\
\hline Salvador & 5 & 8 & 16 & 11 & 13 & 6 & 7 \\
\hline Santa_Cruz_de_Tenerife & 5 & & & & & & \\
\hline Santos & 4 & 6 & 16 & 13 & 15 & 5 & 7 \\
\hline Sines & & & & & & & 7 \\
\hline Tangier & & & 2 & 3 & 3 & & 3 \\
\hline Tanjung_Priok & 6 & 7 & 11 & 9 & 11 & 6 & 3 \\
\hline
\end{tabular}


Vancouver 11

Fonte: autoria própria 
Tabela 40 - Quantidade de vezes que os navios da rota D anunciaram que atracariam nos portos

\begin{tabular}{|c|c|c|c|c|c|c|c|c|c|c|}
\hline Nome Navio & $\begin{array}{l}\text { MSC } \\
\text { ALICANTE }\end{array}$ & $\begin{array}{l}\text { MSC } \\
\text { BARCELONA }\end{array}$ & $\begin{array}{l}\text { MSC } \\
\text { CADIZ } \\
\end{array}$ & $\begin{array}{l}\text { MSC } \\
\text { CORUNA }\end{array}$ & $\begin{array}{l}\text { MSC } \\
\text { MADRID }\end{array}$ & $\begin{array}{l}\text { MSC } \\
\text { MARTA }\end{array}$ & $\begin{array}{l}\text { MSC } \\
\text { VIGO }\end{array}$ & RHODOS & $\begin{array}{l}\text { RIO DE } \\
\text { JANEIRO }\end{array}$ & RIO NEGRO \\
\hline Adelaide & & & & & & & & 3 & & \\
\hline Algeciras & & & & & & 1 & & 9 & & \\
\hline Altamira & & & & & & 1 & & & & \\
\hline Antwerpen & & & & & 13 & 19 & 9 & 4 & & \\
\hline Ashdod & & & & & 8 & 6 & & & & \\
\hline Balboa & & & & & & & 1 & & & \\
\hline Bar & & 1 & & 1 & & & 1 & 1 & & \\
\hline Barcelona & 28 & 35 & 32 & 32 & 29 & 21 & 28 & 6 & 26 & 25 \\
\hline Bremerhaven & & & & & 4 & 14 & 8 & 9 & & \\
\hline Buenos_Aires & 37 & 37 & 40 & 39 & 38 & 23 & 27 & 11 & 28 & 33 \\
\hline Cape_Town & & & & & & & & 7 & & \\
\hline Civitavecchia & & & & & & & 1 & & & \\
\hline Coega & & & & & & & & 2 & & \\
\hline Colombo & & & & & & & & 1 & & \\
\hline Cristobal & & & & & & & 1 & & & \\
\hline Durban & & & & & & & & 7 & & \\
\hline Felixstowe & & & & & 15 & 10 & & & & \\
\hline Fos_sur_Mer & 29 & 41 & 37 & 34 & 33 & 24 & 30 & 11 & 24 & 26 \\
\hline Freeport_Grand_Bahama & & & & & & 1 & & & & \\
\hline Fremantle & & & & & & & & 1 & & \\
\hline Genova & 31 & 34 & 32 & 31 & 29 & 21 & 29 & 11 & 28 & 26 \\
\hline Gioia_Tauro & 27 & 28 & 32 & 32 & 26 & 23 & 28 & 9 & 30 & 25 \\
\hline Haifa & & & & & 8 & 6 & & & & \\
\hline Hamburg & & & & & 13 & 19 & 8 & 1 & & \\
\hline Houston & & & & & & 1 & & & 1 & \\
\hline Itajaí & & & & & & & & 2 & & \\
\hline Itapoá & 33 & 33 & 38 & 37 & 34 & 25 & 27 & 9 & 34 & 31 \\
\hline King_Abdullah_City & & & & & & & & 1 & & \\
\hline La_Spezia & & & & & & 1 & 1 & 3 & & \\
\hline Las_Palmas_de_Gran_Canaria & & & & & & & & 2 & & \\
\hline Le_Havre & & & & & 13 & 19 & 8 & 4 & & \\
\hline Le_Port & & & & & & & & 1 & & \\
\hline Limassol & & & & & 2 & & & & & \\
\hline Lisboa & & & & & & 6 & 6 & & & \\
\hline
\end{tabular}




\begin{tabular}{|c|c|c|c|c|c|c|c|c|c|c|}
\hline Livorno & 32 & 35 & 33 & 35 & 30 & 22 & 30 & 11 & 32 & 28 \\
\hline London_Gateway_Port & & & & & & & & 12 & & \\
\hline Long_Beach & & & & & & & 1 & & & \\
\hline Melbourne & & & & & & & & 3 & & \\
\hline Montevideo & 35 & 35 & 38 & 37 & 36 & 22 & 25 & 11 & 27 & 30 \\
\hline Napoli & & & & & 5 & 7 & & 3 & & \\
\hline Navegantes & 34 & 35 & 38 & 37 & 34 & 31 & 32 & 7 & 33 & 29 \\
\hline New_Orleans & & & & & & 1 & & & & \\
\hline Oakland & & & & & & & 1 & & & \\
\hline Paranagua & & & & & & 12 & 10 & 2 & & \\
\hline Piraeus & & & & & & 1 & & & & \\
\hline Port_de_Pointe_des_Galets & & & & & & & & 2 & & \\
\hline Port_Elizabeth & & & & & & & & 5 & & \\
\hline Port_Everglades & & & & & & 1 & & & & \\
\hline Port_Louis & & & & & & & & 3 & & \\
\hline Rio_de_Janeiro & 36 & 36 & 42 & 38 & 37 & 33 & 38 & 11 & 31 & 31 \\
\hline Rio_Grande & 35 & 35 & 35 & 32 & 36 & 18 & 25 & 8 & 29 & 29 \\
\hline Rotterdam & & & & & 9 & 15 & 8 & 9 & & \\
\hline Salvador & & & & & & 7 & 8 & 2 & & \\
\hline Santos & 37 & 35 & 40 & 37 & 36 & 34 & 38 & 13 & 30 & 31 \\
\hline Sines & & & & & & 7 & 9 & & & \\
\hline Suape & 37 & 37 & 37 & 38 & 38 & 23 & 30 & 11 & 31 & 30 \\
\hline Sydney & & & & & & & & 3 & & \\
\hline Tanger_Med & 11 & 10 & 13 & 11 & 9 & 7 & 9 & 4 & 11 & 9 \\
\hline Tangier & 13 & 13 & 16 & 14 & 12 & 9 & 11 & 4 & 13 & 13 \\
\hline Tanjung_Priok & & & & & & & & 2 & & \\
\hline Valencia & 39 & 40 & 42 & 40 & 39 & 28 & 35 & 14 & 35 & 32 \\
\hline Vancouver & & & & & & & 1 & & & \\
\hline Veracruz & & & & & & 1 & & & & \\
\hline
\end{tabular}


Tabela 41 - Quantidade de vezes que os navios da rota 6 anunciaram que atracariam nos portos

\begin{tabular}{|c|c|c|c|c|c|c|}
\hline Nome Navio & $\begin{array}{l}\text { CMA CGM } \\
\text { BRAZIL }\end{array}$ & $\begin{array}{l}\text { CMA CGM } \\
\text { CAYENNE }\end{array}$ & CMA MARSEILLE & $\begin{array}{l}\text { CMA CGM SAINT } \\
\text { LAURENT }\end{array}$ & $\begin{array}{l}\text { MARFRET } \\
\text { GUYANE }\end{array}$ & $\begin{array}{l}\text { MARFRET } \\
\text { MARAJO }\end{array}$ \\
\hline Algeciras & 18 & 18 & 15 & 16 & 16 & 17 \\
\hline Antwerpen & 1 & 1 & 1 & 1 & 1 & 1 \\
\hline Degrad_des_Cannes & 6 & 11 & 9 & 7 & 11 & 9 \\
\hline Fort_de_France & 1 & & & & & \\
\hline Fortaleza & 9 & 11 & 9 & 8 & 10 & 8 \\
\hline Le_Havre & 9 & 10 & 9 & 9 & 10 & 9 \\
\hline Leixoes & & 1 & 1 & & & \\
\hline Natal & 9 & 11 & 9 & 8 & 10 & 8 \\
\hline Paramaribo & & 1 & & 1 & & 1 \\
\hline Philipsburg & 7 & 10 & 9 & 9 & 11 & 9 \\
\hline Port_of_Spain & 7 & 10 & 9 & 9 & 11 & 9 \\
\hline Rotterdam & 15 & 16 & 13 & 15 & 15 & 16 \\
\hline Tanger_Med & & & & & 1 & \\
\hline Tilbury & 15 & 17 & 14 & 16 & 16 & 16 \\
\hline Vila_do_Conde & 9 & 11 & 9 & 8 & 11 & 9 \\
\hline
\end{tabular}

Fonte: autoria própria 
Tabela 42 - Quantidade de vezes que os navios spot passaram por cada porto

\begin{tabular}{|c|c|c|c|c|c|c|c|c|c|}
\hline Nome Navio & $\begin{array}{l}\text { MSC } \\
\text { MARGARITA }\end{array}$ & DURANDE & DALI & $\begin{array}{l}\text { ELLY } \\
\text { MAERSK }\end{array}$ & $\begin{array}{l}\text { EMMA } \\
\text { MAERSK }\end{array}$ & $\begin{array}{l}\text { ESTELLE } \\
\text { MAERSK }\end{array}$ & $\begin{array}{l}\text { MAERSK } \\
\text { GENOA }\end{array}$ & $\begin{array}{l}\text { MAERSK } \\
\text { GIBRALTAR }\end{array}$ & $\begin{array}{l}\text { MAERSK } \\
\text { GUAYAQUIL }\end{array}$ \\
\hline Aqaba & & & 2 & & & & & & 2 \\
\hline Abidjan & & 5 & & & & & & & \\
\hline Algeciras & & 4 & 10 & & & & 5 & 5 & 8 \\
\hline Antwerpen & 41 & 6 & 7 & 11 & 12 & 14 & 5 & 4 & 7 \\
\hline Apapa & & 2 & & & & & & & \\
\hline As_Suways & & & 4 & & 1 & 2 & & & 4 \\
\hline Barcelona & 12 & & & & & & & & \\
\hline Bremerhaven & 40 & & 7 & 9 & 10 & 16 & 5 & 4 & 9 \\
\hline Buenos_Aires & 13 & & & & & & & & \\
\hline Chiwan & & & & & 1 & & & & \\
\hline Colombo & & & & 3 & 3 & 9 & & & \\
\hline Dakar & & 6 & & & & & & & \\
\hline Degrad_des_C & nes & 1 & & & & & & & \\
\hline Felixstowe & & & 6 & 10 & 13 & 17 & 4 & 3 & 6 \\
\hline Fortaleza & & 1 & & & & & & & \\
\hline Fos_sur_Mer & 14 & & & & & & & & \\
\hline Genova & 12 & & 7 & & & & 3 & 4 & 5 \\
\hline Gioia_Tauro & 10 & & & & & & & & \\
\hline Hamburg & 40 & 3 & 2 & 10 & 11 & 15 & 3 & 3 & 3 \\
\hline Hong_Kong & & & & 7 & 7 & 15 & & & \\
\hline Itapoa & 10 & & & & & & & & \\
\hline Jebel_Ali & & & 13 & 4 & 6 & 9 & 5 & 4 & 9 \\
\hline Jeddah & & & 13 & & & & 5 & 4 & 9 \\
\hline Kobe & & & & & 2 & 3 & & & \\
\hline Le_Havre & 33 & 1 & 2 & 11 & 13 & 15 & 2 & 3 & 3 \\
\hline Lisboa & 29 & & 1 & 1 & 1 & 1 & 1 & 1 & 1 \\
\hline Livorno & 12 & & & & & & & & \\
\hline Montevideo & 13 & & & & & & & & \\
\hline Mundra & & & 6 & & & & 2 & 1 & 5 \\
\hline \multicolumn{2}{|l|}{ Nagoya_Aichi } & & & & 2 & 3 & & & \\
\hline \multicolumn{2}{|l|}{ Nansha } & & & & 1 & & & & \\
\hline \multicolumn{2}{|c|}{ Nansha_New_Port } & & & & 1 & & & & \\
\hline
\end{tabular}




\begin{tabular}{|c|c|c|c|c|c|c|c|c|c|}
\hline Navegantes & 46 & & 1 & 1 & 1 & 1 & 1 & 1 & 1 \\
\hline Nhava_Sheva & & & 13 & & & & 5 & 4 & 9 \\
\hline Ningbo & & & 1 & 9 & 9 & 13 & 1 & 1 & 1 \\
\hline Paranagua & 31 & & 1 & 1 & 1 & 1 & 1 & 1 & 1 \\
\hline Philipsburg & & 1 & & & & & & & \\
\hline Port_of_Spain & & 1 & & & & & & & \\
\hline Rio_de_Janeiro & 47 & & 1 & 1 & 1 & 1 & 1 & 1 & 1 \\
\hline Rio_Grande & 10 & & & & & & & & \\
\hline Rotterdam & 40 & 4 & 7 & 10 & 11 & 17 & 5 & 4 & 9 \\
\hline Salalah & & & 5 & 5 & 6 & 10 & 3 & 2 & 4 \\
\hline Salvador & 31 & & & & & & & & \\
\hline Santos & 45 & & 1 & 1 & 1 & 1 & 1 & 1 & 1 \\
\hline Shanghai & & & 1 & 9 & 9 & 14 & 1 & 1 & 1 \\
\hline Sines & 31 & & 1 & 1 & 2 & 1 & 1 & 1 & 1 \\
\hline Singapore & & & & & 3 & 5 & & & \\
\hline Southampton & & & & & 2 & 2 & & & \\
\hline Suape & 13 & & & & & & & & \\
\hline Tanger_Med & 4 & & & 2 & 4 & 4 & & & \\
\hline Tangier & 3 & 7 & 2 & & 1 & 1 & & & 2 \\
\hline Tanjung_Pelepas & & & & 4 & 5 & 9 & & & \\
\hline Tanjung_Priok & & & 7 & 3 & 3 & 4 & 3 & 4 & 5 \\
\hline Tema & & 3 & & & & & & & \\
\hline Tilbury & & 3 & & & & & & & \\
\hline Valencia & 12 & & & & & & & & \\
\hline Vila_do_Conde & & 1 & & & & & & & \\
\hline Wilhelmshaven & & & 5 & 2 & 4 & 3 & 2 & 2 & 7 \\
\hline Xiamen & & & & & 1 & & & & \\
\hline Yantian & & & & 7 & 8 & 15 & & & \\
\hline Yokohama & & & & & 3 & 3 & & & \\
\hline
\end{tabular}

Fonte: autoria própria 
Tabela 43 - Quantidade de vezes que os navios spot passaram por cada porto

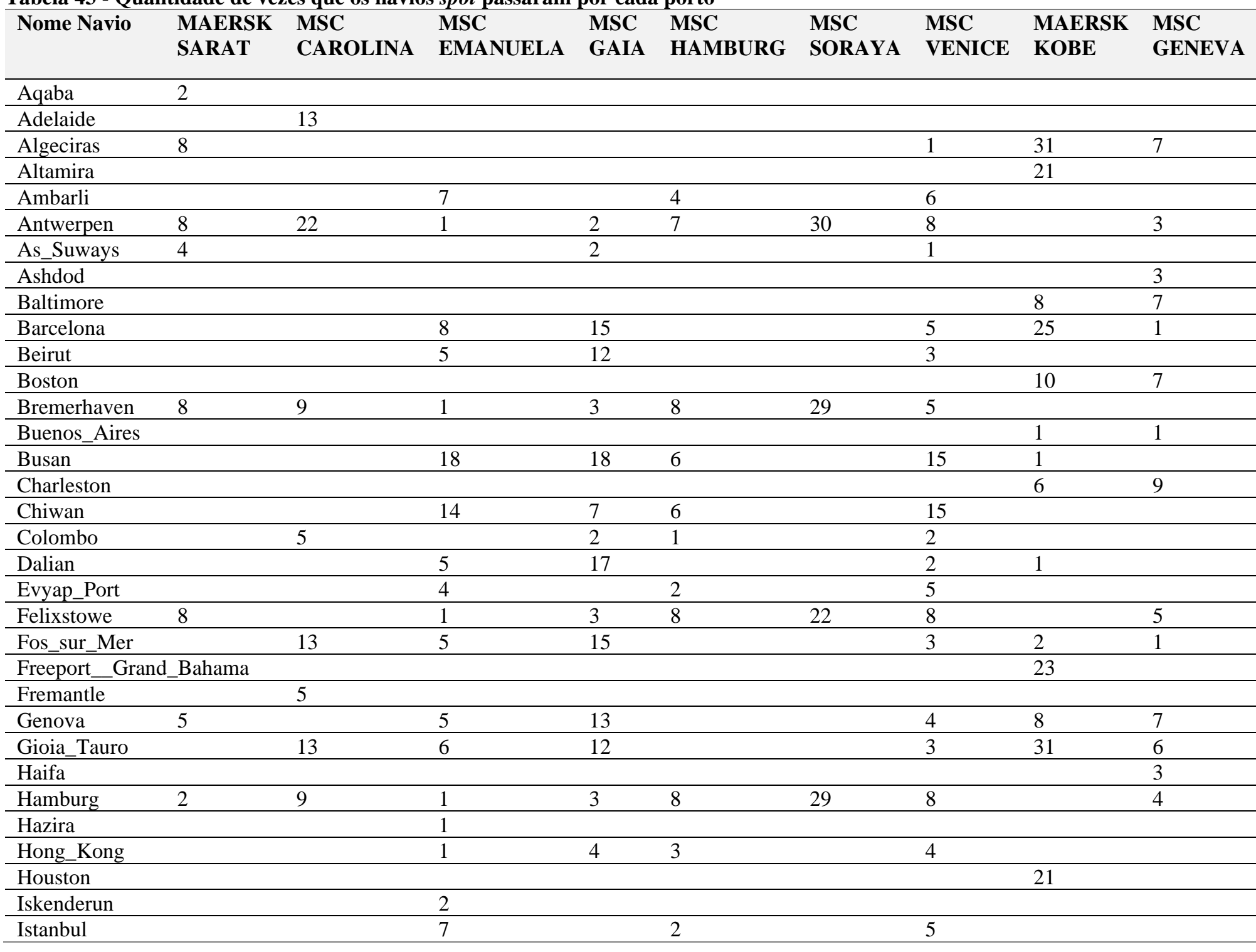




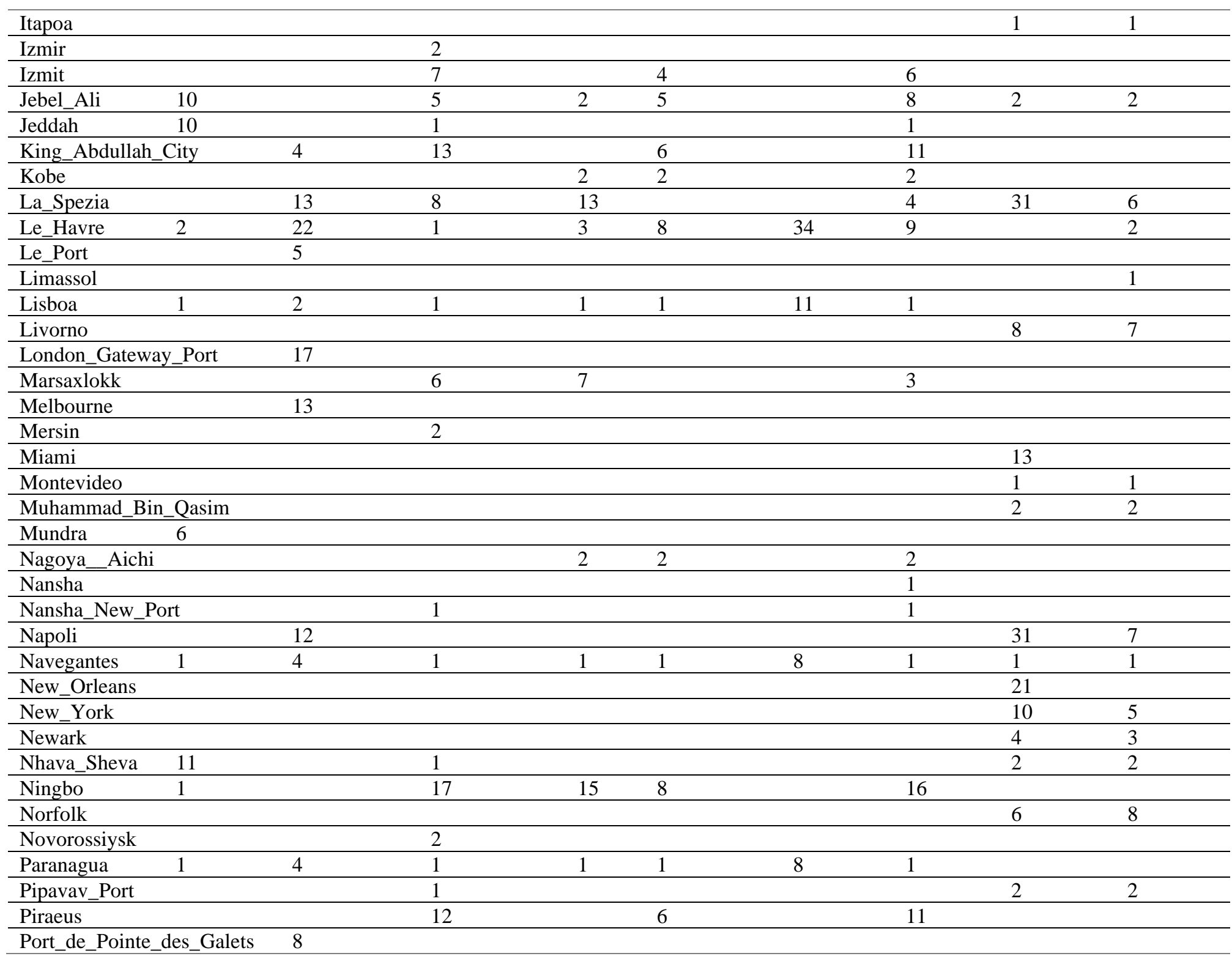


Port_Said

Qingdao

Rio de Janeiro

Rio_Grande

Rotterdam

Salalah

Salvador

Santos

Savannah

Shanghai

Shekou

Sines

Singapore

\begin{tabular}{lll} 
& 2 \\
1 & 13 \\
\hline & 4 & 1
\end{tabular}

\begin{tabular}{lll} 
& 2 \\
\hline & 13 \\
1 & 4 & 1
\end{tabular}

7

Suape

Sydney

Tanger_Med

Tangier

Tanjung_Pelepas

Tanjung_Priok

Tekirdag

Tianjin_Xingang

Valencia

Veracruz

Wilhelmshaven 5

Xiamen

Xingang

Yantian

Yarimca

Yokohama

$\begin{array}{lll} & & \\ 9 & 9 & 1 \\ 5 & & 4 \\ & 4 & \\ 1 & 4 & 1 \\ 1 & & 17 \\ & & 1 \\ 1 & 2 & 1\end{array}$

$\begin{array}{llll}7 & & & 4 \\ 1 & 6 & & 13 \\ 1 & 1 & 8 & 1\end{array}$

13

\begin{tabular}{llllll} 
& & & 1 & 1 \\
2 & 8 & 9 & 8 & 4 \\
10 & 3 & & 6 & & \\
\hline
\end{tabular}

$\begin{array}{lll}10 & 5 \\ 1 & 1 & 8\end{array}$

1

$\begin{array}{llll}17 & 8 & 16 & 6 \\ 1 & & 16\end{array}$

Fonte: autoria própria

$\begin{array}{llll}1 & 1 & 11 & 1 \\ 17 & 7 & & 17\end{array}$

$17 \quad 3$

6

8

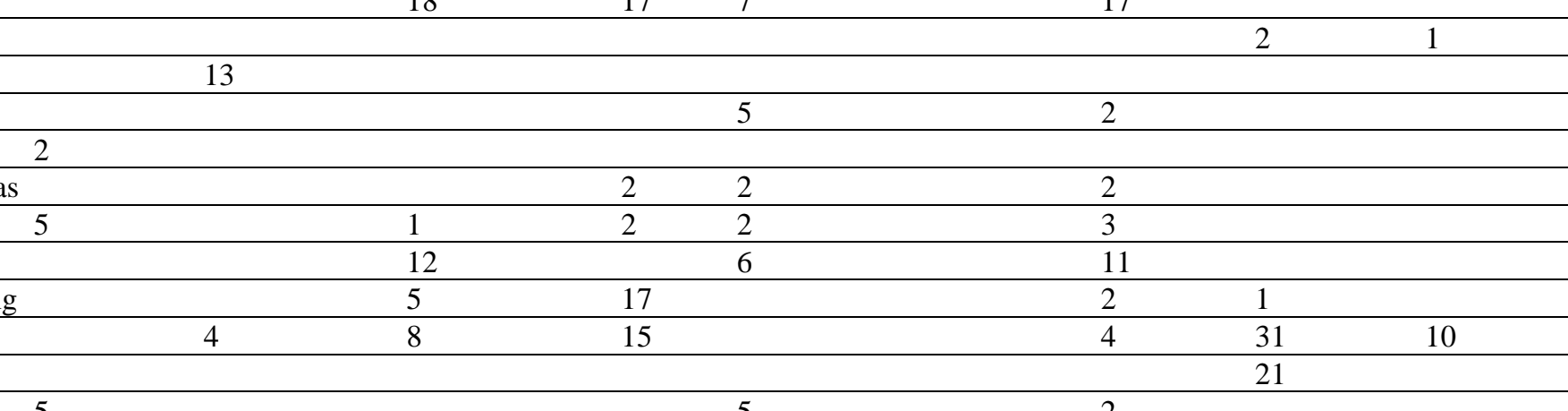

(2)

$\begin{array}{lll} & 5 & 2 \\ 11 & 4 & 9\end{array}$

9


Tabela 44 - Quantidade de vezes que os navios spot passaram por cada porto

\begin{tabular}{|c|c|c|c|c|c|c|c|c|c|}
\hline Nome Navio & $\begin{array}{l}\text { MSC } \\
\text { ILONA }\end{array}$ & $\begin{array}{l}\text { MSC } \\
\text { JUDITH }\end{array}$ & $\begin{array}{l}\text { MSC } \\
\text { KALAMATA }\end{array}$ & $\begin{array}{l}\text { MSC } \\
\text { KOLKATA }\end{array}$ & $\begin{array}{l}\text { MSC } \\
\text { ANNA }\end{array}$ & WIDUKIND & $\begin{array}{l}\text { EBBA } \\
\text { MAERSK }\end{array}$ & $\begin{array}{l}\text { ELEONORA } \\
\text { MAERSK }\end{array}$ & $\begin{array}{l}\text { EUGEN } \\
\text { MAERSK }\end{array}$ \\
\hline Adelaide & 6 & & & & & & & & \\
\hline Algeciras & 29 & 9 & 19 & 20 & 1 & & & & \\
\hline Altamira & 18 & & & & & & & & \\
\hline Antwerpen & 10 & & & & 7 & & 17 & 13 & 11 \\
\hline As_Suways & & & & & 2 & & 2 & & 2 \\
\hline Baltimore & 8 & 6 & 18 & 21 & & & & & \\
\hline Barcelona & 21 & 1 & 2 & 1 & & & & & \\
\hline Beirut & 1 & & 1 & & & & & & \\
\hline Boston & 8 & 6 & 18 & 19 & & & & & \\
\hline Bremerhaven & 4 & & & & 12 & & 18 & 11 & 8 \\
\hline Brisbane & & & & & & 4 & & & \\
\hline Buenos_Aires & 1 & 1 & 1 & 1 & & & & & \\
\hline Busan & 1 & & 1 & & & & & & \\
\hline Cartagena & & & & & & 5 & & & \\
\hline Charleston & 10 & 7 & 19 & 21 & & & & & \\
\hline Chiwan & & & & & & & & & 3 \\
\hline Colombo & 3 & & & & 4 & & 4 & 4 & 2 \\
\hline Dalian & 1 & & 1 & & & & & & \\
\hline Dunkerque & & & & & & 4 & & & \\
\hline Felixstowe & & & & & 13 & & 20 & 13 & 13 \\
\hline Fos_sur_Mer & 9 & 1 & 2 & 1 & & & & & \\
\hline Freeport_Grand_Bahama & 18 & & & & & & & & \\
\hline Fremantle & 3 & & & & & & & & \\
\hline Genova & 12 & 9 & 19 & 18 & & & & & \\
\hline Gioia_Tauro & 34 & 8 & 21 & 18 & & & & & \\
\hline Hamburg & 4 & & & & 7 & & 16 & 13 & 8 \\
\hline Hong_Kong & & & & & 11 & & 18 & 10 & 7 \\
\hline Houston & 18 & & & & & & & & \\
\hline Itajai & & & & & 1 & & & & \\
\hline Itapoa & 1 & 1 & 1 & 1 & 1 & & & & \\
\hline Jebel_Ali & 3 & 2 & 5 & 6 & 5 & & 14 & 7 & 3 \\
\hline King_Abdullah_City & 4 & & & & & & & & \\
\hline Kingston & & & & & & 5 & & & \\
\hline
\end{tabular}


1

La_Spezia

Las_Palmas_de_Gran_Canaria

Le_Havre

34

20

18

Le_Port

10

Lisboa

$10-7$

7

Livorno

11

1

4

17

London_Gateway_Port 10

Lyttelton

Manzanillo_International_Terminal

Marsaxlokk

Melbourne

Miami

Montevideo

Muhammad_Bin_Qasim

2018

1

32

Nagoya Aichi

Nansha

Nansha New Port

Napier

Napoli

Navegantes

New_Orleans

New_York

Newark

Nhava_Sheva

Ningbo

Norfolk

1

(1)

Noumea

1

1

Panama_City

Papeete

Paranagua

Philadelphia

$\begin{array}{ll}1 & \\ 8 & \\ 1 & 1 \\ 3 & 1\end{array}$

4

Pipavav_Port

Port_de_Pointe_des_Galets

Port Everglades

Port_Louis

1
4

Port_of Spain 1

(19)

Prt

1

$\begin{array}{lllll} & & & & 4\end{array}$




\begin{tabular}{|c|c|c|c|c|c|c|c|c|c|}
\hline Rio_de_Janeiro & 1 & 1 & 1 & 1 & 1 & 1 & 3 & 2 & 2 \\
\hline Rio_Grande & 1 & 1 & 1 & 1 & & & & & \\
\hline Rotterdam & 4 & & & & 13 & 4 & 19 & 13 & 11 \\
\hline Salalah & 1 & & 1 & & 5 & & 15 & 7 & 3 \\
\hline Salvador & & & & & 1 & 1 & & & \\
\hline Santos & 1 & 1 & 1 & 1 & 2 & 1 & 3 & 2 & 2 \\
\hline Savannah & 10 & 7 & 19 & 21 & & 4 & & & \\
\hline Shanghai & 1 & & 1 & & 11 & & 16 & 12 & 7 \\
\hline Sines & 26 & 5 & 18 & 18 & 1 & & 3 & 2 & 6 \\
\hline Singapore & 1 & & 1 & & 1 & & 3 & & 5 \\
\hline Southampton & & & & & 4 & & 3 & & 7 \\
\hline Suape & 2 & 1 & 1 & 1 & & & & & \\
\hline Sydney & 6 & & & & & 4 & & & \\
\hline Tanger_Med & & & & & 4 & & 3 & 4 & 4 \\
\hline Tangier & & & & & & & 2 & & 3 \\
\hline Tanjung_Pelepas & & & & & 6 & & 6 & 5 & 7 \\
\hline Tanjung_Priok & & & & & 3 & & 7 & 4 & 4 \\
\hline Tauranga & & & & & & 4 & & & \\
\hline Tianjin_Xingang & 1 & & 1 & & & & & & \\
\hline Tilbury & & & & & & 4 & & & \\
\hline Valencia & 34 & 9 & 19 & 20 & 1 & 1 & & & \\
\hline Veracruz & 18 & & & & & & & & \\
\hline Vila_do_Conde & & & & & & 1 & & & \\
\hline Vitoria & & & & & & 1 & & & \\
\hline Wilhelmshaven & & & & & & & 2 & 4 & 4 \\
\hline Xiamen & & & & & & & 1 & & 4 \\
\hline Yantian & & & & & 11 & & 18 & 10 & 10 \\
\hline Yokohama & & & & & & & 1 & & 4 \\
\hline
\end{tabular}

\section{Fonte: autoria própria}


Tabela 45 - Quantidade de vezes que os navios spot passaram por cada porto

Nome Navio

MAERSK MAERSK MAERSK MSC

MSC MSC MSC MSC MSC

SALTORO SHAMS STADELHORN AMSTERDAM ELOANE ERICA ISTANBUL MIRJAM KINGSTON

Aqaba

Abu_Dhabi

Ad_Dammam

Algeciras

Antwerpen

Arhus

As_Suways

Baltimore

Barcelona

Beirut

$2 \quad 2$

Boston 3

Bremerhaven

Buenos_Aires

Busan

Charleston

Chiwan

Colombo

Dalian

Felixstowe

$\begin{array}{ll}2 & 2 \\ 1 & \\ 1 & \\ 8 & 7 \\ 9 & 8\end{array}$

$\begin{array}{ll}6 & 8 \\ 8 & 9\end{array}$

1
1
13

3

20

Fos_sur_Mer

Gdansk

Genova

Gioia_Tauro

Gwangyang

Hamburg

Hong_Kong

8

13

3
10

$\begin{array}{ll}11 & 9 \\ 1 & \end{array}$

$\begin{array}{lll}3 & 1 \\ & 3 & 2\end{array}$

8

$5 \quad 5$

$5 \quad 4$

4

1

6

$\begin{array}{ll}3 & 2 \\ 1 & 5 \\ 1 & 1\end{array}$

$\begin{array}{ll}2 & \\ 5 & 23 \\ 1 & 2\end{array}$

Itapoa

Jebel_Al

Jeddah

Jubail

King_Abdullah_City

8

$9 \quad 8 \quad 12$

$\begin{array}{llll}1 & 1 & & \\ 1 & & & 23 \\ 18 & 14 & 9 & 14\end{array}$

23

$\begin{array}{llll} & & & 14 \\ 4 & 1 & 5 & 2\end{array}$

\begin{tabular}{lllll} 
& & & & 23 \\
1 & & 4 & & \\
6 & 3 & 2 & 6 & \\
3 & & 1 & & \\
20 & 10 & 10 & 14 & \\
1 & & 1 & & 20 \\
2 & & & & 20 \\
1 & & 1 & & \\
1 & & 2 & & \\
2 & & & 11 & \\
9 & 12 & 10 & & \\
13 & 10 & 6 & & \\
\hline 5 & & & & \\
\hline & & & & \\
\hline
\end{tabular}




\begin{tabular}{|c|c|c|c|c|c|c|c|c|c|}
\hline \multicolumn{4}{|l|}{ Kobe } & \multicolumn{3}{|l|}{1} & \multicolumn{3}{|l|}{1} \\
\hline La_Spezia & & & & 5 & 1 & & \multicolumn{2}{|l|}{5} & 20 \\
\hline Le_Havre & 3 & 4 & 3 & 14 & 9 & 11 & 10 & 8 & \\
\hline Lisboa & 2 & 2 & 2 & 2 & 2 & 2 & 2 & 2 & \\
\hline \multicolumn{4}{|l|}{ Livorno } & & & & & & 20 \\
\hline \multicolumn{2}{|l|}{ Marsaxlokk } & 1 & & 5 & & & 5 & & \\
\hline \multicolumn{4}{|l|}{ Montevideo } & & & & & & 2 \\
\hline \multicolumn{4}{|c|}{ Muhammad_Bin_Qasim } & & & & & & 6 \\
\hline Mundra & 6 & 5 & 6 & & & & & & \\
\hline \multicolumn{4}{|l|}{ Nagoya_Aichi } & 1 & & & 1 & & \\
\hline \multicolumn{4}{|l|}{ Nansha } & 5 & & & 2 & & \\
\hline \multicolumn{4}{|c|}{ Nansha_New_Port } & 3 & & & 1 & & \\
\hline \multicolumn{4}{|c|}{ Napoli } & & & & & & 20 \\
\hline Navegantes & 2 & 2 & 2 & 2 & 2 & 2 & 2 & 2 & 2 \\
\hline \multicolumn{4}{|l|}{ New_York } & & & & & & 21 \\
\hline \multicolumn{4}{|l|}{ Newark } & & & & & & 14 \\
\hline Nhava_Sheva & 10 & 8 & 10 & & & & & & 6 \\
\hline \multicolumn{2}{|l|}{ Ningbo } & 1 & & 19 & 16 & 12 & 11 & 11 & \\
\hline \multicolumn{4}{|l|}{ Norfolk } & & & & & & 23 \\
\hline Paranagua & 2 & 2 & 2 & 2 & 2 & 2 & 2 & 2 & \\
\hline \multicolumn{4}{|l|}{ Pipavav_Port } & & & & & & 6 \\
\hline \multicolumn{2}{|l|}{ Port_Said } & 1 & & 3 & 1 & & & & \\
\hline \multicolumn{2}{|l|}{ Qingdao } & & & 7 & 1 & 1 & 4 & & \\
\hline Rio_de_Janeiro & 2 & 2 & 2 & 2 & 2 & 2 & 2 & 2 & 2 \\
\hline \multicolumn{4}{|l|}{ Rio_Grande } & & & & & & 2 \\
\hline Rotterdam & 8 & 9 & 8 & 13 & 16 & 13 & 10 & 15 & \\
\hline Salalah & 5 & 5 & 4 & 8 & 6 & 9 & 6 & 6 & \\
\hline Santos & 2 & 2 & 2 & 2 & 2 & 2 & 2 & 2 & 2 \\
\hline Savannah & & & & & & & & & 23 \\
\hline Shanghai & & 1 & & 18 & 17 & 13 & 11 & 11 & \\
\hline Shekou & & & & 2 & & & & & \\
\hline Sines & 2 & 2 & 2 & 2 & 2 & 2 & 2 & 2 & 19 \\
\hline Singapore & & & & 10 & 3 & 2 & 6 & 3 & \\
\hline Southampton & & & & 1 & 6 & 1 & & 6 & \\
\hline Suape & & & & & & & & & 2 \\
\hline Tanger_Med & & & & 3 & 4 & 1 & 3 & 5 & \\
\hline Tangier & 1 & 2 & 2 & & 1 & 1 & & 1 & \\
\hline
\end{tabular}




\begin{tabular}{|c|c|c|c|c|c|c|c|c|}
\hline Tanjung_Pelepas & & & & 5 & 11 & 3 & 3 & 6 \\
\hline Tanjung_Priok & 4 & 5 & 5 & 6 & 3 & 4 & 3 & 3 \\
\hline Tianjin_Xingang & & & & & 2 & 2 & 1 & \\
\hline Valencia & & 1 & & 6 & & & 5 & 20 \\
\hline Wilhelmshaven & 5 & 6 & 5 & 3 & 1 & 1 & 3 & \\
\hline Xiamen & & & & 9 & 1 & & 4 & \\
\hline Yantian & & & & 16 & 16 & 10 & 9 & 10 \\
\hline Yokohama & & & & 1 & & & 1 & \\
\hline
\end{tabular}

Fonte: autoria própria 
Tabela 46 - Quantidade de vezes que os navios spot passaram por cada porto

\begin{tabular}{|c|c|c|c|c|c|c|c|c|c|}
\hline Nome Navio & $\begin{array}{l}\text { MSC } \\
\text { MARGARITA }\end{array}$ & DURANDE & DALI & $\begin{array}{l}\text { ELLY } \\
\text { MAERSK }\end{array}$ & $\begin{array}{l}\text { EMMA } \\
\text { MAERSK }\end{array}$ & $\begin{array}{l}\text { ESTELLE } \\
\text { MAERSK }\end{array}$ & $\begin{array}{l}\text { MAERSK } \\
\text { GENOA }\end{array}$ & $\begin{array}{l}\text { MAERSK } \\
\text { GIBRALTAR }\end{array}$ & $\begin{array}{l}\text { MAERSK } \\
\text { GUAYAQUIL }\end{array}$ \\
\hline Aqaba & & & 2 & & & & & & 2 \\
\hline Abidjan & & 5 & & & & & & & \\
\hline Algeciras & & 4 & 10 & & & & 5 & 5 & 8 \\
\hline Antwerpen & 41 & 6 & 7 & 11 & 12 & 14 & 5 & 4 & 7 \\
\hline Apapa & & 2 & & & & & & & \\
\hline As_Suways & & & 4 & & 1 & 2 & & & 4 \\
\hline Barcelona & 12 & & & & & & & & \\
\hline Bremerhaven & 40 & & 7 & 9 & 10 & 16 & 5 & 4 & 9 \\
\hline Buenos_Aires & 13 & & & & & & & & \\
\hline Chiwan & & & & & 1 & & & & \\
\hline Colombo & & & & 3 & 3 & 9 & & & \\
\hline Dakar & & 6 & & & & & & & \\
\hline Degrad_des_C & nes & 1 & & & & & & & \\
\hline Felixstowe & & & 6 & 10 & 13 & 17 & 4 & 3 & 6 \\
\hline Fortaleza & & 1 & & & & & & & \\
\hline Fos_sur_Mer & 14 & & & & & & & & \\
\hline Genova & 12 & & 7 & & & & 3 & 4 & 5 \\
\hline Gioia_Tauro & 10 & & & & & & & & \\
\hline Hamburg & 40 & 3 & 2 & 10 & 11 & 15 & 3 & 3 & 3 \\
\hline Hong_Kong & & & & 7 & 7 & 15 & & & \\
\hline Itapoa & 10 & & & & & & & & \\
\hline Jebel_Ali & & & 13 & 4 & 6 & 9 & 5 & 4 & 9 \\
\hline Jeddah & & & 13 & & & & 5 & 4 & 9 \\
\hline Kobe & & & & & 2 & 3 & & & \\
\hline Le_Havre & 33 & 1 & 2 & 11 & 13 & 15 & 2 & 3 & 3 \\
\hline Lisboa & 29 & & 1 & 1 & 1 & 1 & 1 & 1 & 1 \\
\hline Livorno & 12 & & & & & & & & \\
\hline Montevideo & 13 & & & & & & & & \\
\hline Mundra & & & 6 & & & & 2 & 1 & 5 \\
\hline \multicolumn{2}{|l|}{ Nagoya_Aichi } & & & & 2 & 3 & & & \\
\hline \multicolumn{2}{|l|}{ Nansha } & & & & 1 & & & & \\
\hline \multicolumn{2}{|c|}{ Nansha_New_Port } & & & & 1 & & & & \\
\hline
\end{tabular}




\begin{tabular}{|c|c|c|c|c|c|c|c|c|c|}
\hline Navegantes & 46 & & 1 & 1 & 1 & 1 & 1 & 1 & 1 \\
\hline Nhava_Sheva & & & 13 & & & & 5 & 4 & 9 \\
\hline Ningbo & & & 1 & 9 & 9 & 13 & 1 & 1 & 1 \\
\hline Paranagua & 31 & & 1 & 1 & 1 & 1 & 1 & 1 & 1 \\
\hline Philipsburg & & 1 & & & & & & & \\
\hline Port_of_Spain & & 1 & & & & & & & \\
\hline Rio_de_Janeiro & 47 & & 1 & 1 & 1 & 1 & 1 & 1 & 1 \\
\hline Rio_Grande & 10 & & & & & & & & \\
\hline Rotterdam & 40 & 4 & 7 & 10 & 11 & 17 & 5 & 4 & 9 \\
\hline Salalah & & & 5 & 5 & 6 & 10 & 3 & 2 & 4 \\
\hline Salvador & 31 & & & & & & & & \\
\hline Santos & 45 & & 1 & 1 & 1 & 1 & 1 & 1 & 1 \\
\hline Shanghai & & & 1 & 9 & 9 & 14 & 1 & 1 & 1 \\
\hline Sines & 31 & & 1 & 1 & 2 & 1 & 1 & 1 & 1 \\
\hline Singapore & & & & & 3 & 5 & & & \\
\hline Southampton & & & & & 2 & 2 & & & \\
\hline Suape & 13 & & & & & & & & \\
\hline Tanger_Med & 4 & & & 2 & 4 & 4 & & & \\
\hline Tangier & 3 & 7 & 2 & & 1 & 1 & & & 2 \\
\hline Tanjung_Pelepas & & & & 4 & 5 & 9 & & & \\
\hline Tanjung_Priok & & & 7 & 3 & 3 & 4 & 3 & 4 & 5 \\
\hline Tema & & 3 & & & & & & & \\
\hline Tilbury & & 3 & & & & & & & \\
\hline Valencia & 12 & & & & & & & & \\
\hline Vila_do_Conde & & 1 & & & & & & & \\
\hline Wilhelmshaven & & & 5 & 2 & 4 & 3 & 2 & 2 & 7 \\
\hline Xiamen & & & & & 1 & & & & \\
\hline Yantian & & & & 7 & 8 & 15 & & & \\
\hline Yokohama & & & & & 3 & 3 & & & \\
\hline
\end{tabular}

Fonte: autoria própria 
Tabela 47 - Quantidade de vezes que os navios spot passaram por cada porto

\begin{tabular}{|c|c|c|c|c|c|c|c|c|c|}
\hline Nome Navio & $\begin{array}{l}\text { MAERSK } \\
\text { SARAT }\end{array}$ & $\begin{array}{l}\text { MSC } \\
\text { CAROLINA }\end{array}$ & $\begin{array}{l}\text { MSC } \\
\text { EMANUELA }\end{array}$ & $\begin{array}{l}\text { MSC } \\
\text { GAIA }\end{array}$ & $\begin{array}{l}\text { MSC } \\
\text { HAMBURG }\end{array}$ & $\begin{array}{l}\text { MSC } \\
\text { SORAYA }\end{array}$ & $\begin{array}{l}\text { MSC } \\
\text { VENICE }\end{array}$ & $\begin{array}{l}\text { MAERSK } \\
\text { KOBE }\end{array}$ & $\begin{array}{l}\text { MSC } \\
\text { GENEVA }\end{array}$ \\
\hline Aqaba & 2 & & & & & & & & \\
\hline Adelaide & & 13 & & & & & & & \\
\hline Algeciras & 8 & & & & & & 1 & 31 & 7 \\
\hline Altamira & & & & & & & & 21 & \\
\hline Ambarli & & & 7 & & 4 & & 6 & & \\
\hline Antwerpen & 8 & 22 & 1 & 2 & 7 & 30 & 8 & & 3 \\
\hline As_Suways & 4 & & & 2 & & & 1 & & \\
\hline Ashdod & & & & & & & & & 3 \\
\hline Baltimore & & & & & & & & 8 & 7 \\
\hline Barcelona & & & 8 & 15 & & & 5 & 25 & 1 \\
\hline Beirut & & & 5 & 12 & & & 3 & & \\
\hline Boston & & & & & & & & 10 & 7 \\
\hline Bremerhaven & 8 & 9 & 1 & 3 & 8 & 29 & 5 & & \\
\hline Buenos_Aires & & & & & & & & 1 & 1 \\
\hline Busan & & & 18 & 18 & 6 & & 15 & 1 & \\
\hline Charleston & & & & & & & & 6 & 9 \\
\hline Chiwan & & & 14 & 7 & 6 & & 15 & & \\
\hline Colombo & & 5 & & 2 & 1 & & 2 & & \\
\hline Dalian & & & 5 & 17 & & & 2 & 1 & \\
\hline Evyap_Port & & & 4 & & 2 & & 5 & & \\
\hline Felixstowe & 8 & & 1 & 3 & 8 & 22 & 8 & & 5 \\
\hline Fos_sur_Mer & & 13 & 5 & 15 & & & 3 & 2 & 1 \\
\hline Freeport_Grand & Bahama & & & & & & & 23 & \\
\hline Fremantle & & 5 & & & & & & & \\
\hline Genova & 5 & & 5 & 13 & & & 4 & 8 & 7 \\
\hline Gioia_Tauro & & 13 & 6 & 12 & & & 3 & 31 & 6 \\
\hline Haifa & & & & & & & & & 3 \\
\hline Hamburg & 2 & 9 & 1 & 3 & 8 & 29 & 8 & & 4 \\
\hline Hazira & & & 1 & & & & & & \\
\hline Hong_Kong & & & 1 & 4 & 3 & & 4 & & \\
\hline Houston & & & & & & & & 21 & \\
\hline Iskenderun & & & 2 & & & & & & \\
\hline Istanbul & & & 7 & & 2 & & 5 & & \\
\hline
\end{tabular}




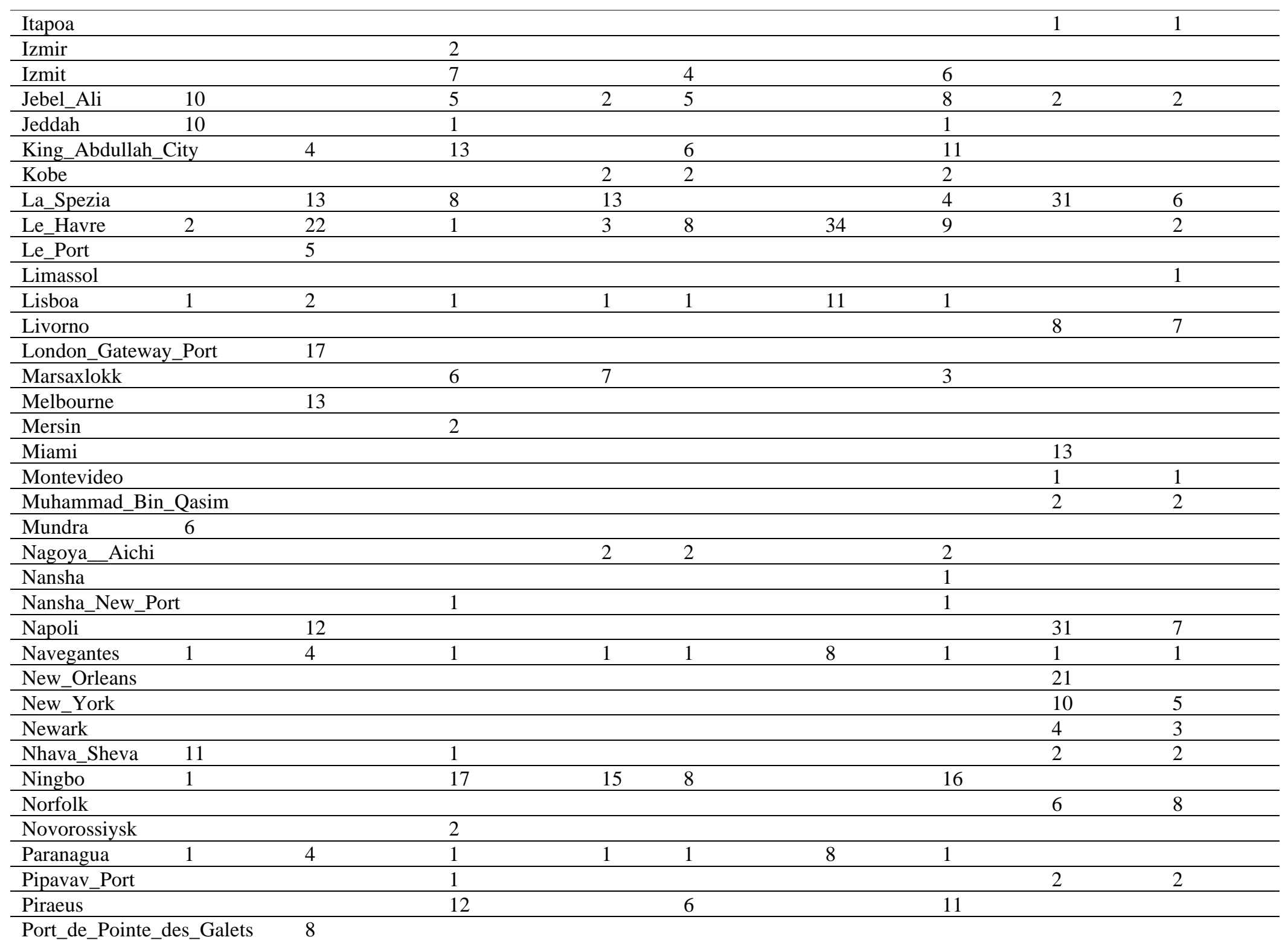


Port_Said

Qingdao

Rio_de_Janeiro

Rio_Grande

Rotterdam

Salalah

Salvador

Santos

Savannah

Shanghai

Shekou

Sines

Singapore

2

2

$\begin{array}{ll}2 & 7 \\ 13 & 1\end{array}$

Suape

Sydney

Tanger_Med

Tangier

Tanjung_Pelepas

Tanjung_Priok

Tekirdag

Tianjin_Xingang

Valencia

Veracruz

Wilhelmshaven 5

Xiamen

Xingang

Yantian

Yarimca

Yokohama

$\begin{array}{ll}1 & 4 \\ 9 & 9 \\ 5 & \end{array}$

$\begin{array}{lllll}1 & & & & \\ 1 & 2 & 8 & 9 & 8\end{array}$

Fonte: autoria

$2 \quad 8$

$\begin{array}{lll} & 4 & \\ 1 & 4 & 1 \\ 1 & & 17 \\ 1 & & 1 \\ 1 & 2 & 18\end{array}$

$\begin{array}{lll} & & 5 \\ 1 & 1 & 8\end{array}$

5

6

$\begin{array}{ll}2 & 1 \\ 1 & 1 \\ & 4\end{array}$

$\begin{array}{lll}17 & & \\ 1 & & \\ 1 & 1 & 11 \\ 17 & 7 & \end{array}$

\begin{tabular}{ll}
1 & 2 \\
16 & 6 \\
\hline
\end{tabular}

\begin{tabular}{lll}
1 & 6 & 8 \\
\hline 16 & 1 & \\
\hline & & \\
\hline 1 & 31 & 5 \\
\hline & & \\
\hline
\end{tabular}

13

5

\begin{tabular}{|c|c|c|c|c|}
\hline & & & 5 & 2 \\
\hline \multicolumn{5}{|l|}{2} \\
\hline is & & 2 & 2 & 2 \\
\hline 5 & 1 & 2 & 2 & 3 \\
\hline & 12 & & 6 & 1 \\
\hline$g$ & 5 & 17 & & 2 \\
\hline
\end{tabular}

\begin{tabular}{lll}
\hline 2 & & \\
3 & & \\
11 & & \\
\hline 2 & 1 & \\
4 & 31 & 10 \\
\hline & 21 & \\
\hline
\end{tabular}

toria própria 


\begin{tabular}{|c|c|c|c|c|c|c|c|c|c|}
\hline Nome Navio & $\begin{array}{l}\text { MSC } \\
\text { ILONA }\end{array}$ & $\begin{array}{l}\text { MSC } \\
\text { JUDITH }\end{array}$ & $\begin{array}{l}\text { MSC } \\
\text { KALAMATA }\end{array}$ & $\begin{array}{l}\text { MSC } \\
\text { KOLKATA }\end{array}$ & $\begin{array}{l}\text { MSC } \\
\text { ANNA }\end{array}$ & WIDUKIND & $\begin{array}{l}\text { EBBA } \\
\text { MAERSK }\end{array}$ & $\begin{array}{l}\text { ELEONORA } \\
\text { MAERSK }\end{array}$ & $\begin{array}{l}\text { EUGEN } \\
\text { MAERSK }\end{array}$ \\
\hline Adelaide & 6 & & & & & & & & \\
\hline Algeciras & 29 & 9 & 19 & 20 & 1 & & & & \\
\hline Altamira & 18 & & & & & & & & \\
\hline Antwerpen & 10 & & & & 7 & & 17 & 13 & 11 \\
\hline As_Suways & & & & & 2 & & 2 & & 2 \\
\hline Baltimore & 8 & 6 & 18 & 21 & & & & & \\
\hline Barcelona & 21 & 1 & 2 & 1 & & & & & \\
\hline Beirut & 1 & & 1 & & & & & & \\
\hline Boston & 8 & 6 & 18 & 19 & & & & & \\
\hline Bremerhaven & 4 & & & & 12 & & 18 & 11 & 8 \\
\hline Brisbane & & & & & & 4 & & & \\
\hline Buenos_Aires & 1 & 1 & 1 & 1 & & & & & \\
\hline Busan & 1 & & 1 & & & & & & \\
\hline Cartagena & & & & & & 5 & & & \\
\hline Charleston & 10 & 7 & 19 & 21 & & & & & \\
\hline Chiwan & & & & & & & & & 3 \\
\hline Colombo & 3 & & & & 4 & & 4 & 4 & 2 \\
\hline Dalian & 1 & & 1 & & & & & & \\
\hline Dunkerque & & & & & & 4 & & & \\
\hline Felixstowe & & & & & 13 & & 20 & 13 & 13 \\
\hline Fos_sur_Mer & 9 & 1 & 2 & 1 & & & & & \\
\hline Freeport_Grand_Bahama & 18 & & & & & & & & \\
\hline Fremantle & 3 & & & & & & & & \\
\hline Genova & 12 & 9 & 19 & 18 & & & & & \\
\hline Gioia_Tauro & 34 & 8 & 21 & 18 & & & & & \\
\hline Hamburg & 4 & & & & 7 & & 16 & 13 & 8 \\
\hline Hong_Kong & & & & & 11 & & 18 & 10 & 7 \\
\hline Houston & 18 & & & & & & & & \\
\hline Itajai & & & & & 1 & & & & \\
\hline Itapoa & 1 & 1 & 1 & 1 & 1 & & & & \\
\hline Jebel_Ali & 3 & 2 & 5 & 6 & 5 & & 14 & 7 & 3 \\
\hline King_Abdullah_City & 4 & & & & & & & & \\
\hline Kingston & & & & & & 5 & & & \\
\hline
\end{tabular}


La_Spezia

Las_Palmas_de_Gran_Canaria

Le_Havre

34

$8 \quad 20$

1

2

Le_Port

$\begin{array}{ll}18 & 1 \\ 10 & 7\end{array}$

Lisboa

Livorno

2018

1

$17 \quad 13$

London_Gateway_Port 10

Lyttelton

Manzanillo_International_Terminal

Marsaxlokk

Melbourne

Miami

Montevideo

Muhammad_Bin_Qasim

Nagoya_Aichi

Nansha

Nansha New Port

Napier

Napoli

$11-9 \quad 20$

18

10

20

New Orleans

New_York

Newark

Nhava_Sheva

Ningbo

Norfolk

Noumea

Panama_City

Papeete

Paranagua

$\begin{array}{ll}\text { nal } & \\ 1 & \\ 6 & \\ 8 & \\ 1 & 1 \\ 3 & 1\end{array}$

Philadelphia

Pipavav_Port

Port_de_Pointe_des_Galets

Port_Everglades

Port_Louis

Port_of_Spain

1

$\begin{array}{lllll} & & & & 18\end{array}$

\begin{tabular}{lllllllll}
3 & 8 & 21 & 18 & 2 & 1 & 3 & 2 & 2 \\
18 & 1 & 1 & 1 & & & & \\
6 & 4 & 18 & 19 & 4 & & \\
\hline
\end{tabular}

\begin{tabular}{lllllllll}
1 & 1 & 1 & 1 & 2 & 1 & 3 & 2 & 2 \\
18 & & & & & & & \\
6 & 4 & 18 & 19 & 4 & & \\
\hline
\end{tabular}

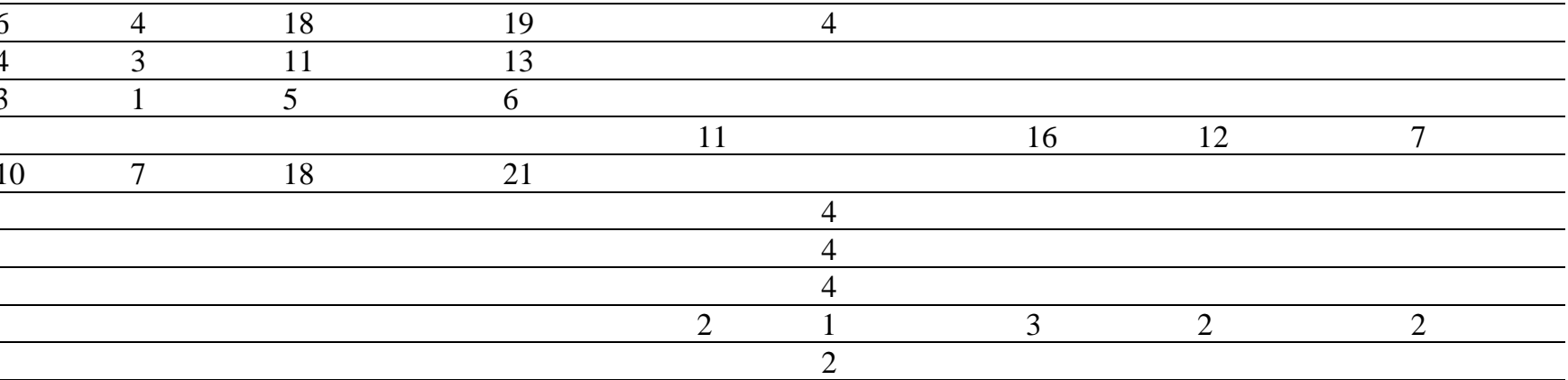

$\begin{array}{llll}3 & 5 & 6\end{array}$

4 


\begin{tabular}{|c|c|c|c|c|c|c|c|c|c|}
\hline Rio_de_Janeiro & 1 & 1 & 1 & 1 & 1 & 1 & 3 & 2 & 2 \\
\hline Rio_Grande & 1 & 1 & 1 & 1 & & & & & \\
\hline Rotterdam & 4 & & & & 13 & 4 & 19 & 13 & 11 \\
\hline Salalah & 1 & & 1 & & 5 & & 15 & 7 & 3 \\
\hline Salvador & & & & & 1 & 1 & & & \\
\hline Santos & 1 & 1 & 1 & 1 & 2 & 1 & 3 & 2 & 2 \\
\hline Savannah & 10 & 7 & 19 & 21 & & 4 & & & \\
\hline Shanghai & 1 & & 1 & & 11 & & 16 & 12 & 7 \\
\hline Sines & 26 & 5 & 18 & 18 & 1 & & 3 & 2 & 6 \\
\hline Singapore & 1 & & 1 & & 1 & & 3 & & 5 \\
\hline Southampton & & & & & 4 & & 3 & & 7 \\
\hline Suape & 2 & 1 & 1 & 1 & & & & & \\
\hline Sydney & 6 & & & & & 4 & & & \\
\hline Tanger_Med & & & & & 4 & & 3 & 4 & 4 \\
\hline Tangier & & & & & & & 2 & & 3 \\
\hline Tanjung_Pelepas & & & & & 6 & & 6 & 5 & 7 \\
\hline Tanjung_Priok & & & & & 3 & & 7 & 4 & 4 \\
\hline Tauranga & & & & & & 4 & & & \\
\hline Tianjin_Xingang & 1 & & 1 & & & & & & \\
\hline Tilbury & & & & & & 4 & & & \\
\hline Valencia & 34 & 9 & 19 & 20 & 1 & 1 & & & \\
\hline Veracruz & 18 & & & & & & & & \\
\hline Vila_do_Conde & & & & & & 1 & & & \\
\hline Vitoria & & & & & & 1 & & & \\
\hline Wilhelmshaven & & & & & & & 2 & 4 & 4 \\
\hline Xiamen & & & & & & & 1 & & 4 \\
\hline Yantian & & & & & 11 & & 18 & 10 & 10 \\
\hline Yokohama & & & & & & & 1 & & 4 \\
\hline
\end{tabular}

\section{Fonte: autoria própria}


Tabela 49 - Quantidade de vezes que os navios spot passaram por cada porto

\begin{tabular}{|c|c|c|c|c|c|c|c|c|c|}
\hline Nome Navio & $\begin{array}{l}\text { MAERSK } \\
\text { SALTORO }\end{array}$ & $\begin{array}{l}\text { MAERSK } \\
\text { SHAMS }\end{array}$ & $\begin{array}{l}\text { MAERSK } \\
\text { STADELHORN }\end{array}$ & $\begin{array}{l}\text { MSC } \\
\text { AMSTERDAM }\end{array}$ & $\begin{array}{l}\text { MSC } \\
\text { ELOANE }\end{array}$ & $\begin{array}{l}\text { MSC } \\
\text { ERICA }\end{array}$ & $\begin{array}{l}\text { MSC } \\
\text { ISTANBUL }\end{array}$ & $\begin{array}{l}\text { MSC } \\
\text { MIRJAM }\end{array}$ & $\begin{array}{l}\text { MSC } \\
\text { KINGSTON }\end{array}$ \\
\hline Aqaba & 3 & 2 & 2 & & & & & & \\
\hline Abu_Dhabi & & 1 & & 1 & & & & & \\
\hline Ad_Dammam & & 1 & & 1 & & & & & \\
\hline Algeciras & 6 & 8 & 7 & 1 & 3 & & & & 20 \\
\hline Antwerpen & 8 & 9 & 8 & 13 & 10 & 11 & 9 & 8 & \\
\hline Arhus & & & & & & 1 & & & \\
\hline As_Suways & 5 & 5 & 4 & 3 & 3 & 2 & & 2 & \\
\hline Baltimore & & & & & & & & & 23 \\
\hline Barcelona & & 1 & & 6 & 1 & & 5 & & 2 \\
\hline Beirut & & & & & 1 & & 1 & & \\
\hline Boston & & & & & & & & & 23 \\
\hline Bremerhaven & 8 & 9 & 8 & 12 & 18 & 14 & 9 & 14 & \\
\hline Buenos_Aires & & & & & & & & & 2 \\
\hline Busan & & & & 7 & 4 & 1 & 5 & & \\
\hline Charleston & & & & & & & & & 23 \\
\hline Chiwan & & & & 6 & 1 & & 4 & & \\
\hline Colombo & & & & 4 & 6 & 3 & 2 & 6 & \\
\hline Dalian & & & & & 3 & & 1 & & \\
\hline Felixstowe & 6 & 7 & 6 & 14 & 20 & 10 & 10 & 14 & \\
\hline Fos_sur_Mer & & & & & 1 & & 1 & & 2 \\
\hline Gdansk & & & & & 2 & & & & \\
\hline Genova & 4 & 5 & 5 & 1 & 1 & & 1 & & 20 \\
\hline Gioia_Tauro & & & & 2 & 1 & & 2 & & 20 \\
\hline Gwangyang & & & & & 2 & & & & \\
\hline Hamburg & 3 & 4 & 3 & 13 & 9 & 12 & 10 & 8 & \\
\hline Hong_Kong & & & & 10 & 13 & 10 & 6 & 11 & \\
\hline Itapoa & & & & & & & & & 2 \\
\hline Jebel_Ali & 10 & 10 & 10 & 10 & 5 & 8 & 6 & 4 & 6 \\
\hline Jeddah & 10 & 9 & 9 & 1 & & & & & \\
\hline Jubail & & 1 & & 1 & & & & & \\
\hline King_Abdullah & & & & 2 & & & 1 & & \\
\hline Kobe & & & & 1 & & & 1 & & \\
\hline La_Spezia & & & & 5 & 1 & & 5 & & 20 \\
\hline
\end{tabular}




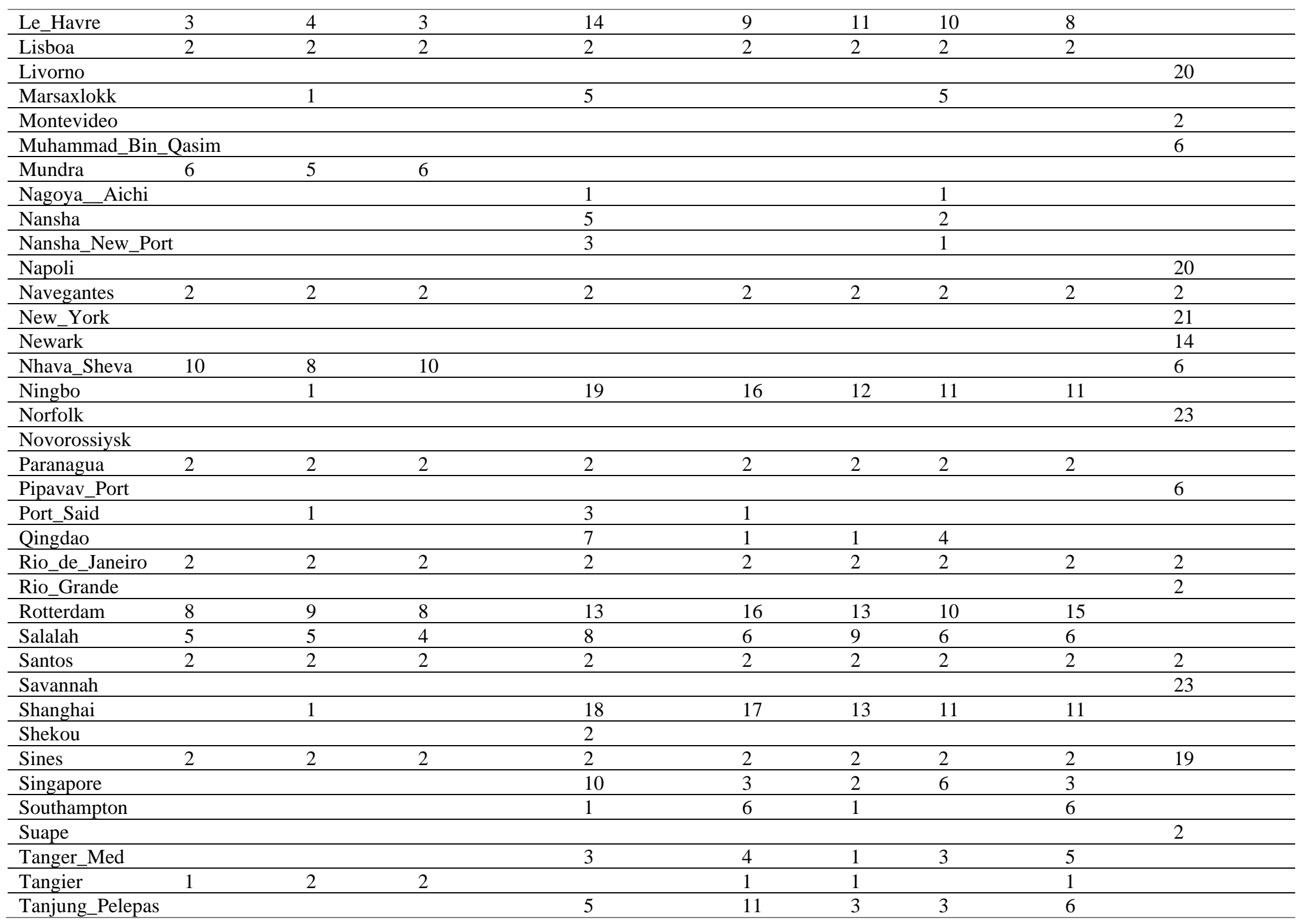




\begin{tabular}{|c|c|c|c|c|c|c|c|c|}
\hline Tanjung_Priok & 4 & 5 & 5 & 6 & 3 & 4 & 3 & 3 \\
\hline Tianjin_Xingang & & & & & 2 & 2 & 1 & \\
\hline Valencia & & 1 & & 6 & & & 5 & 20 \\
\hline Wilhelmshaven & 5 & 6 & 5 & 3 & 1 & 1 & 3 & \\
\hline Xiamen & & & & 9 & 1 & & 4 & \\
\hline Yantian & & & & 16 & 16 & 10 & 9 & 10 \\
\hline Yokohama & & & & 1 & & & 1 & \\
\hline
\end{tabular}

\section{Fonte: autoria própria}




\section{APÊNDICE D - DESCRIÇÃO DA ROTA DOS NAVIOS SELECIONADOS}

Tabela 50 - Parte da rota do Cap San Antonio, navio da rota A, durante os anos de 2016 e 2017

\begin{tabular}{|c|c|c|c|c|c|}
\hline Porto & Data & Paranagua & $21 / 10 / 2016$ & Le Havre & $13 / 01 / 2017$ \\
\hline Santos & $11 / 08 / 2016$ & Santos & $22 / 10 / 2016$ & Santos & $26 / 01 / 2017$ \\
\hline Paranagua & $13 / 08 / 2016$ & Tanger Med & 05/11/2016 & Paranagua & $28 / 01 / 2017$ \\
\hline Buenos Aires & $17 / 08 / 2016$ & Rotterdam & $09 / 11 / 2016$ & Buenos Aires & $31 / 01 / 2017$ \\
\hline Montevideo & $19 / 08 / 2016$ & London Gateway Port & $11 / 11 / 2016$ & Montevideo & $02 / 02 / 2017$ \\
\hline Rio Grande & $21 / 08 / 2016$ & Hamburg & $13 / 11 / 2016$ & Rio Grande & $04 / 02 / 2017$ \\
\hline Itapoa & $24 / 08 / 2016$ & Antwerpen & $16 / 11 / 2016$ & Itapoa & $07 / 02 / 2017$ \\
\hline Paranagua & $25 / 08 / 2016$ & Le Havre & $17 / 11 / 2016$ & Paranagua & $10 / 02 / 2017$ \\
\hline Santos & $27 / 08 / 2016$ & Santos & $01 / 12 / 2016$ & Santos & $11 / 02 / 2017$ \\
\hline Tanger Med & $10 / 09 / 2016$ & Paranagua & $03 / 12 / 2016$ & Tanger Med & $25 / 02 / 2017$ \\
\hline Rotterdam & $14 / 09 / 2016$ & Buenos Aires & $06 / 12 / 2016$ & Rotterdam & $01 / 03 / 2017$ \\
\hline London Gateway Port & $16 / 09 / 2016$ & Montevideo & $09 / 12 / 2016$ & London Gateway Port & $04 / 03 / 2017$ \\
\hline Hamburg & $18 / 09 / 2016$ & Rio Grande & $11 / 12 / 2016$ & Hamburg & $05 / 03 / 2017$ \\
\hline Antwerpen & $20 / 09 / 2016$ & Itapoa & $14 / 12 / 2016$ & Antwerpen & 08/03/2017 \\
\hline Le Havre & $22 / 09 / 2016$ & Paranagua & $16 / 12 / 2016$ & Le Havre & $10 / 03 / 2017$ \\
\hline Santos & $06 / 10 / 2016$ & Santos & $18 / 12 / 2016$ & Santos & $23 / 03 / 2017$ \\
\hline Paranagua & 09/10/2016 & Tanger Med & 01/01/2017 & Paranagua & $25 / 03 / 2017$ \\
\hline Buenos Aires & $13 / 10 / 2016$ & Rotterdam & $05 / 01 / 2017$ & Buenos Aires & $29 / 03 / 2017$ \\
\hline Montevideo & $15 / 10 / 2016$ & London Gateway Port & $06 / 01 / 2017$ & Montevideo & $31 / 03 / 2017$ \\
\hline Rio Grande & $17 / 10 / 2016$ & Hamburg & 08/01/2017 & Rio Grande & $02 / 04 / 2017$ \\
\hline Itapoa & $19 / 10 / 2016$ & Antwerpen & $10 / 01 / 2017$ & Itapoa & $05 / 04 / 2017$ \\
\hline
\end{tabular}

\begin{tabular}{ll} 
Paranagua & $06 / 04 / 2017$ \\
Santos & $08 / 04 / 2017$ \\
\hline \hline Tanger Med & $24 / 04 / 2017$ \\
Rotterdam & $27 / 04 / 2017$ \\
London Gateway Port & $29 / 04 / 2017$ \\
Hamburg & $01 / 05 / 2017$ \\
Antwerpen & $04 / 05 / 2017$ \\
Le Havre & $06 / 05 / 2017$ \\
\hline Santos & $18 / 05 / 2017$ \\
Paranagua & $20 / 05 / 2017$ \\
Buenos Aires & $23 / 05 / 2017$ \\
Montevideo & $25 / 05 / 2017$ \\
Rio Grande & $28 / 05 / 2017$ \\
Itapoa & $30 / 05 / 2017$ \\
Paranagua & $01 / 06 / 2017$ \\
Santos & $03 / 06 / 2017$ \\
\hline \hline Tanger Med & $17 / 06 / 2017$ \\
Rotterdam & $21 / 06 / 2017$
\end{tabular}

Fonte: autoria própria

Antwerpen

Itapoa

$05 / 04 / 2017$ 
Tabela 51 - Parte da rota do MSC Krystal, navio da rota B, durante os anos de 2016 e 2017

\begin{tabular}{|c|c|c|c|c|c|c|c|c|c|}
\hline Porto & Data & Le Havre & $11 / 10 / 2016$ & Navegantes & $19 / 12 / 2016$ & Bremerhaven & $06 / 03 / 2017$ & Paranagua & $16 / 05 / 2017$ \\
\hline Antwerpen & $16 / 08 / 2016$ & Lisboa & $14 / 10 / 2016$ & Santos & $22 / 12 / 2016$ & Le Havre & $08 / 03 / 2017$ & Navegantes & $17 / 05 / 2017$ \\
\hline Rotterdam & $17 / 08 / 2016$ & Sines & $16 / 10 / 2016$ & $\mathrm{RJ}$ & $23 / 12 / 2016$ & Lisboa & $11 / 03 / 2017$ & Santos & $23 / 05 / 2017$ \\
\hline Hamburg & $19 / 08 / 2016$ & RJ & $27 / 10 / 2016$ & Salvador & $27 / 12 / 2016$ & Sines & $12 / 03 / 2017$ & $\mathrm{RJ}$ & $24 / 05 / 2017$ \\
\hline Bremerhaven & $21 / 08 / 2016$ & Santos & $28 / 10 / 2016$ & Rotterdam & 12/01/2017 & $\mathrm{RJ}$ & $22 / 03 / 2017$ & Salvador & $26 / 05 / 2017$ \\
\hline Le Havre & $23 / 08 / 2016$ & Paranagua & $29 / 10 / 2016$ & Hamburg & $14 / 01 / 2017$ & Santos & $24 / 03 / 2017$ & Hamburg & "11/06/2017 \\
\hline Lisboa & $26 / 08 / 2016$ & Navegantes & $31 / 10 / 2016$ & Bremerhaven & $15 / 01 / 2017$ & Paranagua & $25 / 03 / 2017$ & Bremerhaven & $12 / 06 / 2017$ \\
\hline Sines & $27 / 08 / 2016$ & Santos & $04 / 11 / 2016$ & Le Havre & $17 / 01 / 2017$ & Navegantes & $27 / 03 / 2017$ & Le Havre & $15 / 06 / 2017$ \\
\hline RJ & $07 / 09 / 2016$ & RJ & $05 / 11 / 2016$ & Lisboa & $20 / 01 / 2017$ & Santos & $30 / 03 / 2017$ & Lisboa & $18 / 06 / 2017$ \\
\hline Paranagua & $10 / 09 / 2016$ & "Rotterdam & 25/11/2016 & RJ & $01 / 02 / 2017$ & Salvador & $04 / 04 / 2017$ & RJ & $28 / 06 / 2017$ \\
\hline Navegantes & $12 / 09 / 2016$ & Hamburg & $27 / 11 / 2016$ & Santos & 03/02/2017 & "Rotterdam & 20/04/2017 & Santos & 01/07/2017 \\
\hline Santos & $15 / 09 / 2016$ & Bremerhaven & $29 / 11 / 2016$ & Paranagua & $04 / 02 / 2017$ & Hamburg & $22 / 04 / 2017$ & Paranagua & $03 / 07 / 2017$ \\
\hline RJ & $17 / 09 / 2016$ & Le Havre & $01 / 12 / 2016$ & Navegantes & 06/02/2017 & Bremerhaven & $24 / 04 / 2017$ & Navegantes & $05 / 07 / 2017$ \\
\hline Salvador & $20 / 09 / 2016$ & Sines & $03 / 12 / 2016$ & Santos & $09 / 02 / 2017$ & Le Havre & $26 / 04 / 2017$ & Santos & $06 / 07 / 2017$ \\
\hline A Antwerpen & 04/10/2016 & Lisboa & $04 / 12 / 2016$ & $\mathrm{RJ}$ & $10 / 02 / 2017$ & Lisboa & $29 / 04 / 2017$ & $\mathrm{RJ}$ & 08/07/2017 \\
\hline Rotterdam & $05 / 10 / 2016$ & RJ & $15 / 12 / 2016$ & Salvador & $14 / 02 / 2017$ & Sines & $03 / 05 / 2017$ & Salvador & $11 / 07 / 2017$ \\
\hline Hamburg & $07 / 10 / 2016$ & Santos & $16 / 12 / 2016$ & Rotterdam & 02/03/2017 & $\mathrm{RJ}$ & $13 / 05 / 2017$ & & \\
\hline
\end{tabular}


Tabela 52 - Parte da rota do MSC Fiammetta, navio da rota B, durante os anos de 2016 e 2017

\begin{tabular}{ll}
\hline Porto & Data \\
\hline Felixstowe & $06 / 08 / 2016$ \\
Bremerhaven & $07 / 08 / 2016$ \\
\hline Hamburg & $08 / 08 / 2016$ \\
\hline \hline Antwerpen & $11 / 08 / 2016$ \\
Rotterdam & $23 / 08 / 2016$ \\
\hline Hamburg & $25 / 08 / 2016$ \\
\hline \hline Bremerhaven & $27 / 08 / 2016$ \\
Le Havre & $29 / 08 / 2016$ \\
Lisboa & $01 / 09 / 2016$ \\
Sines & $02 / 09 / 2016$ \\
Felixstowe & $04 / 09 / 2016$ \\
Bremerhaven & $05 / 09 / 2016$ \\
\hline Hamburg & $07 / 09 / 2016$ \\
\hline \hline Antwerpen & $09 / 09 / 2016$ \\
Felixstowe & $02 / 10 / 2016$ \\
Bremerhaven & $04 / 10 / 2016$ \\
\hline Hamburg & $05 / 10 / 2016$ \\
\hline \hline Antwerpen & $07 / 10 / 2016$
\end{tabular}

\begin{tabular}{ll} 
Felixstowe & $30 / 10 / 2016$ \\
Bremerhaven & $01 / 11 / 2016$ \\
\hline Hamburg & $02 / 11 / 2016$ \\
\hline \hline Antwerpen & $05 / 11 / 2016$ \\
\hline Hamburg & $27 / 11 / 2016$ \\
\hline \hline Bremerhaven & $29 / 11 / 2016$ \\
Felixstowe & $01 / 12 / 2016$ \\
Antwerpen & $02 / 12 / 2016$ \\
London Gateway Port & $27 / 12 / 2016$ \\
\hline Hamburg & $28 / 12 / 2016$ \\
\hline \hline Bremerhaven & $31 / 12 / 2016$ \\
Antwerpen & $05 / 01 / 2017$ \\
Felixstowe & $29 / 01 / 2017$ \\
Bremerhaven & $31 / 01 / 2017$ \\
\hline Hamburg & $01 / 02 / 2017$ \\
\hline \hline Antwerpen & $03 / 02 / 2017$ \\
Felixstowe & $27 / 02 / 2017$ \\
Bremerhaven & $28 / 02 / 2017$ \\
\hline Hamburg & $01 / 03 / 2017$ \\
\hline \hline
\end{tabular}

\begin{tabular}{ll} 
Antwerpen & $04 / 03 / 2017$ \\
Antwerpen & $04 / 04 / 2017$ \\
Le Havre & $07 / 04 / 2017$ \\
Lisboa & $09 / 04 / 2017$ \\
Sines & $11 / 04 / 2017$ \\
\hline RJ & $20 / 04 / 2017$ \\
Santos & $22 / 04 / 2017$ \\
Paranagua & $23 / 04 / 2017$ \\
Navegantes & $24 / 04 / 2017$ \\
Santos & $27 / 04 / 2017$ \\
RJ & $30 / 04 / 2017$ \\
Salvador & $02 / 05 / 2017$ \\
\hline \hline Antwerpen & $16 / 05 / 2017$ \\
Rotterdam & $17 / 05 / 2017$ \\
Hamburg & $19 / 05 / 2017$ \\
Bremerhaven & $22 / 05 / 2017$ \\
Le Havre & $25 / 05 / 2017$ \\
Lisboa & $29 / 05 / 2017$ \\
Sines & $30 / 05 / 2017$ \\
\hline RJ & $08 / 06 / 2017$
\end{tabular}

\begin{tabular}{ll} 
Santos & $09 / 06 / 2017$ \\
Navegantes & $11 / 06 / 2017$ \\
Paranagua & $11 / 06 / 2017$ \\
Santos & $15 / 06 / 2017$ \\
RJ & $17 / 06 / 2017$ \\
Salvador & $20 / 06 / 2017$ \\
\hline \hline Antwerpen & $04 / 07 / 2017$ \\
Rotterdam & $05 / 07 / 2017$ \\
Hamburg & $07 / 07 / 2017$ \\
Bremerhaven & $11 / 07 / 2017$ \\
Le Havre & $13 / 07 / 2017$ \\
Lisboa & $15 / 07 / 2017$ \\
Sines & $16 / 07 / 2017$ \\
\hline RJ & $27 / 07 / 2017$ \\
Santos & $28 / 07 / 2017$ \\
Paranagua & $29 / 07 / 2017$ \\
Navegantes & $31 / 07 / 2017$ \\
Salvador & $08 / 08 / 2017$ \\
\hline \hline
\end{tabular}

Fonte: autoria própria 
Tabela 53 - Parte da rota do MSC Vidhi, navio da rota B, durante os anos de 2016 e 2017

\begin{tabular}{ll}
\hline Porto & Data \\
\hline Salalah & $03 / 08 / 2016$ \\
Jeddah & $07 / 08 / 2016$ \\
As Suways & $09 / 08 / 2016$ \\
Tangier & $15 / 08 / 2016$ \\
Felixstowe & $19 / 08 / 2016$ \\
Antwerpen & $21 / 08 / 2016$ \\
Bremerhaven & $23 / 08 / 2016$ \\
Wilhelmshaven & $24 / 08 / 2016$ \\
Rotterdam & $26 / 08 / 2016$ \\
Algeciras & $31 / 08 / 2016$ \\
As Suways & $05 / 09 / 2016$ \\
'Aqaba & $07 / 09 / 2016$
\end{tabular}

$\begin{array}{ll}\text { Jeddah } & 11 / 09 / 2016 \\ \text { Jebel Ali } & 17 / 09 / 2016 \\ \text { Nhava Sheva } & 22 / 09 / 2016 \\ \text { Mundra } & 24 / 09 / 2016 \\ \text { Salalah } & 28 / 09 / 2016 \\ \text { Jeddah } & 02 / 10 / 2016 \\ \text { As Suways } & 04 / 10 / 2016 \\ \text { Tangier } & 10 / 10 / 2016 \\ \text { Felixstowe } & 14 / 10 / 2016 \\ \text { Antwerpen } & 16 / 10 / 2016 \\ \text { Bremerhaven } & 18 / 10 / 2016 \\ \text { Wilhelmshaven } & 19 / 10 / 2016 \\ \text { Rotterdam } & 21 / 10 / 2016 \\ \text { Algeciras } & 26 / 10 / 2016\end{array}$

\begin{tabular}{ll} 
Algeciras & 29/01/2017 \\
Santos & $09 / 02 / 2017$ \\
Paranagua & $11 / 02 / 2017$ \\
Itajai & $12 / 02 / 2017$ \\
Buenos Aires & $15 / 02 / 2017$ \\
Montevideo & $17 / 02 / 2017$ \\
Rio Grande & $19 / 02 / 2017$ \\
Santos & $22 / 02 / 2017$ \\
Pecem & $28 / 02 / 2017$ \\
\hline \hline Algeciras & $06 / 03 / 2017$ \\
Rotterdam & $11 / 03 / 2017$ \\
Tilbury & $13 / 03 / 2017$ \\
London Gateway Port & $14 / 03 / 2017$
\end{tabular}

\begin{tabular}{ll} 
Bremerhaven & $16 / 03 / 2017$ \\
Antwerpen & $18 / 03 / 2017$ \\
Le Havre & $21 / 03 / 2017$ \\
Algeciras & $24 / 03 / 2017$ \\
\hline Santos & $04 / 04 / 2017$ \\
Paranagua & $06 / 04 / 2017$ \\
Itajai & $07 / 04 / 2017$ \\
Buenos Aires & $10 / 04 / 2017$ \\
Montevideo & $12 / 04 / 2017$ \\
Rio Grande & $14 / 04 / 2017$ \\
Santos & $20 / 04 / 2017$ \\
Pecem & $23 / 04 / 2017$ \\
\hline \hline
\end{tabular}

Fonte: autoria própria

Tabela 54 - Parte da rota do MSC Azov, navio da rota C, durante os anos de 2016 e 2017

\begin{tabular}{|c|c|c|c|}
\hline Porto & Data & Salvador & $07 / 05 / 2017$ \\
\hline Salvador & $24 / 03 / 2017$ & Itapoa & $11 / 05 / 2017$ \\
\hline Itapoa & $28 / 03 / 2017$ & Paranagua & $12 / 05 / 2017$ \\
\hline Paranagua & $29 / 03 / 2017$ & Itajai & $13 / 05 / 2017$ \\
\hline Itajai & $30 / 03 / 2017$ & Navegantes & $14 / 05 / 2017$ \\
\hline Navegantes & $31 / 03 / 2017$ & $\underline{\text { Santos }}$ & $16 / 05 / 2017$ \\
\hline Santos & $02 / 04 / 2017$ & $\begin{array}{c}\text { Las Palmas de Gran Canaria } \\
\end{array}$ & 27/05/2017 \\
\hline Las Palmas de Gran Canaria & $13 / 04 / 2017$ & Algeciras & $30 / 05 / 2017$ \\
\hline Algeciras & $16 / 04 / 2017$ & Valencia & $02 / 06 / 2017$ \\
\hline Valencia & $19 / 04 / 2017$ & Tanjung Priok & $05 / 06 / 2017$ \\
\hline Tanjung Priok & $22 / 04 / 2017$ & Salvador & $20 / 06 / 2017$ \\
\hline
\end{tabular}

\begin{tabular}{ll} 
Itapoa & $24 / 06 / 2017$ \\
Paranagua & $25 / 06 / 2017$ \\
Itajai & $26 / 06 / 2017$ \\
Navegantes & $27 / 06 / 2017$ \\
Santos & $29 / 06 / 2017$ \\
\hline \hline Las Palmas de Gran Canaria & $08 / 07 / 2017$ \\
Algeciras & $13 / 07 / 2017$ \\
Valencia & $14 / 07 / 2017$ \\
Tanjung Priok & $19 / 07 / 2017$
\end{tabular}


Tabela 55 - Parte da rota do navio Rio de Janeiro, navio da rota D, durante os anos de 2016 e 2017

\begin{tabular}{ll}
\hline Porto & Data \\
\hline Rio Grande & $01 / 08 / 2016$ \\
Navegantes & $03 / 08 / 2016$ \\
Itapoa & $04 / 08 / 2016$ \\
Santos & $05 / 08 / 2016$ \\
Rio de Janeiro & $07 / 08 / 2016$ \\
Suape & $11 / 08 / 2016$ \\
\hline \hline Tanger Med & $19 / 08 / 2016$ \\
Tangier & $20 / 08 / 2016$ \\
Valencia & $21 / 08 / 2016$ \\
Gioia Tauro & $24 / 08 / 2016$ \\
Livorno & $27 / 08 / 2016$ \\
Genova & $28 / 08 / 2016$ \\
Fos-sur-Mer & $31 / 08 / 2016$ \\
Barcelona & $01 / 09 / 2016$ \\
Valencia & $02 / 09 / 2016$ \\
\hline Suape & $12 / 09 / 2016$ \\
Rio de Janeiro & $15 / 09 / 2016$ \\
Santos & $17 / 09 / 2016$ \\
Buenos Aires & $20 / 09 / 2016$ \\
Montevideo & $22 / 09 / 2016$ \\
Rio Grande & $24 / 09 / 2016$ \\
Navegantes & $27 / 09 / 2016$ \\
Itapoa & $29 / 09 / 2016$ \\
Santos & $30 / 09 / 2016$ \\
Rio de Janeiro & $02 / 10 / 2016$ \\
Suape & $06 / 10 / 2016$ \\
\hline \hline
\end{tabular}

\begin{tabular}{ll} 
Tangier & $14 / 10 / 2016$ \\
Valencia & $16 / 10 / 2016$ \\
Gioia Tauro & $19 / 10 / 2016$ \\
Livorno & $22 / 10 / 2016$ \\
Genova & $23 / 10 / 2016$ \\
Fos-sur-Mer & $26 / 10 / 2016$ \\
Barcelona & $27 / 10 / 2016$ \\
Valencia & $28 / 10 / 2016$ \\
\hline Suape & $07 / 11 / 2016$ \\
Rio de Janeiro & $11 / 11 / 2016$ \\
Santos & $12 / 11 / 2016$ \\
Buenos Aires & $15 / 11 / 2016$ \\
Montevideo & $17 / 11 / 2016$ \\
Rio Grande & $20 / 11 / 2016$ \\
Navegantes & $22 / 11 / 2016$ \\
Itapoa & $24 / 11 / 2016$ \\
Santos & $25 / 11 / 2016$ \\
Rio de Janeiro & $27 / 11 / 2016$ \\
Suape & $30 / 11 / 2016$ \\
\hline \hline Tangier & $09 / 12 / 2016$ \\
Tanger Med & $09 / 12 / 2016$ \\
Valencia & $11 / 12 / 2016$ \\
\hline Gioia Tauro & $14 / 12 / 2016$ \\
Livorno & $17 / 12 / 2016$ \\
Genova & $18 / 12 / 2016$ \\
Fos-sur-Mer & $21 / 12 / 2016$ \\
Barcelona & $22 / 12 / 2016$
\end{tabular}

\begin{tabular}{ll} 
Valencia & $23 / 12 / 2016$ \\
Suape & $03 / 01 / 2017$ \\
\hline \hline Rio de Janeiro & $06 / 01 / 2017$ \\
Santos & $07 / 01 / 2017$ \\
Buenos Aires & $10 / 01 / 2017$ \\
Montevideo & $12 / 01 / 2017$ \\
Rio Grande & $14 / 01 / 2017$ \\
Navegantes & $17 / 01 / 2017$ \\
Itapoa & $19 / 01 / 2017$ \\
Santos & $20 / 01 / 2017$ \\
Rio de Janeiro & $22 / 01 / 2017$ \\
Suape & $28 / 01 / 2017$ \\
\hline \hline Tanger Med & $03 / 02 / 2017$ \\
Tangier & $05 / 02 / 2017$ \\
Valencia & $06 / 02 / 2017$ \\
Gioia Tauro & $08 / 02 / 2017$ \\
Genova & $11 / 02 / 2017$ \\
Livorno & $12 / 02 / 2017$ \\
Fos-sur-Mer & $14 / 02 / 2017$ \\
Barcelona & $17 / 02 / 2017$ \\
Valencia & $18 / 02 / 2017$ \\
\hline Suape & $01 / 03 / 2017$ \\
Rio de Janeiro & $03 / 03 / 2017$ \\
Santos & $03 / 03 / 2017$ \\
Buenos Aires & $07 / 03 / 2017$ \\
Montevideo & $10 / 03 / 2017$ \\
Rio Grande & $11 / 03 / 2017$
\end{tabular}

\begin{tabular}{ll} 
Navegantes & $14 / 03 / 2017$ \\
Itapoa & $16 / 03 / 2017$ \\
Santos & $18 / 03 / 2017$ \\
Rio de Janeiro & $20 / 03 / 2017$ \\
Suape & $23 / 03 / 2017$ \\
\hline \hline Tanger Med & $31 / 03 / 2017$ \\
Tangier & $31 / 03 / 2017$ \\
Valencia & $02 / 04 / 2017$ \\
Gioia Tauro & $05 / 04 / 2017$ \\
Genova & $08 / 04 / 2017$ \\
Livorno & $09 / 04 / 2017$ \\
Fos-sur-Mer & $11 / 04 / 2017$ \\
Barcelona & $15 / 04 / 2017$ \\
Valencia & $17 / 04 / 2017$ \\
\hline Suape & $26 / 04 / 2017$ \\
Rio de Janeiro & $27 / 04 / 2017$ \\
Santos & $29 / 04 / 2017$ \\
Buenos Aires & $02 / 05 / 2017$ \\
Montevideo & $04 / 05 / 2017$ \\
Rio Grande & $06 / 05 / 2017$ \\
Navegantes & $11 / 05 / 2017$ \\
Itapoa & $12 / 05 / 2017$ \\
Santos & $13 / 05 / 2017$ \\
Rio de Janeiro & $15 / 05 / 2017$ \\
Suape & $17 / 05 / 2017$ \\
\hline \hline Tanger Med & $26 / 05 / 2017$ \\
Tangier & $26 / 05 / 2017$
\end{tabular}

\begin{tabular}{ll} 
Valencia & $28 / 05 / 2017$ \\
\hline Gioia Tauro & $31 / 05 / 2017$ \\
Livorno & $06 / 06 / 2017$ \\
Genova & $07 / 06 / 2017$ \\
Fos-sur-Mer & $09 / 06 / 2017$ \\
Barcelona & $10 / 06 / 2017$ \\
Valencia & $12 / 06 / 2017$ \\
\hline Suape & $21 / 06 / 2017$ \\
Rio de Janeiro & $25 / 06 / 2017$ \\
Santos & $26 / 06 / 2017$ \\
Buenos Aires & $29 / 06 / 2017$ \\
Montevideo & $01 / 07 / 2017$ \\
Rio Grande & $03 / 07 / 2017$ \\
Navegantes & $05 / 07 / 2017$ \\
Itapoa & $06 / 07 / 2017$ \\
Santos & $07 / 07 / 2017$ \\
Rio de Janeiro & $09 / 07 / 2017$ \\
Suape & $12 / 07 / 2017$ \\
\hline \hline Tanger Med & $21 / 07 / 2017$ \\
Tangier & $24 / 07 / 2017$ \\
Valencia & $25 / 07 / 2017$ \\
\hline Gioia Tauro & $28 / 07 / 2017$ \\
Livorno & $30 / 07 / 2017$ \\
Genova & $31 / 07 / 2017$
\end{tabular}

Fonte: autoria própria

Rio Grande 11/03/2017 
Tabela 56 - Parte da rota do navio MSC Madrid durante os anos de 2016 e 2017

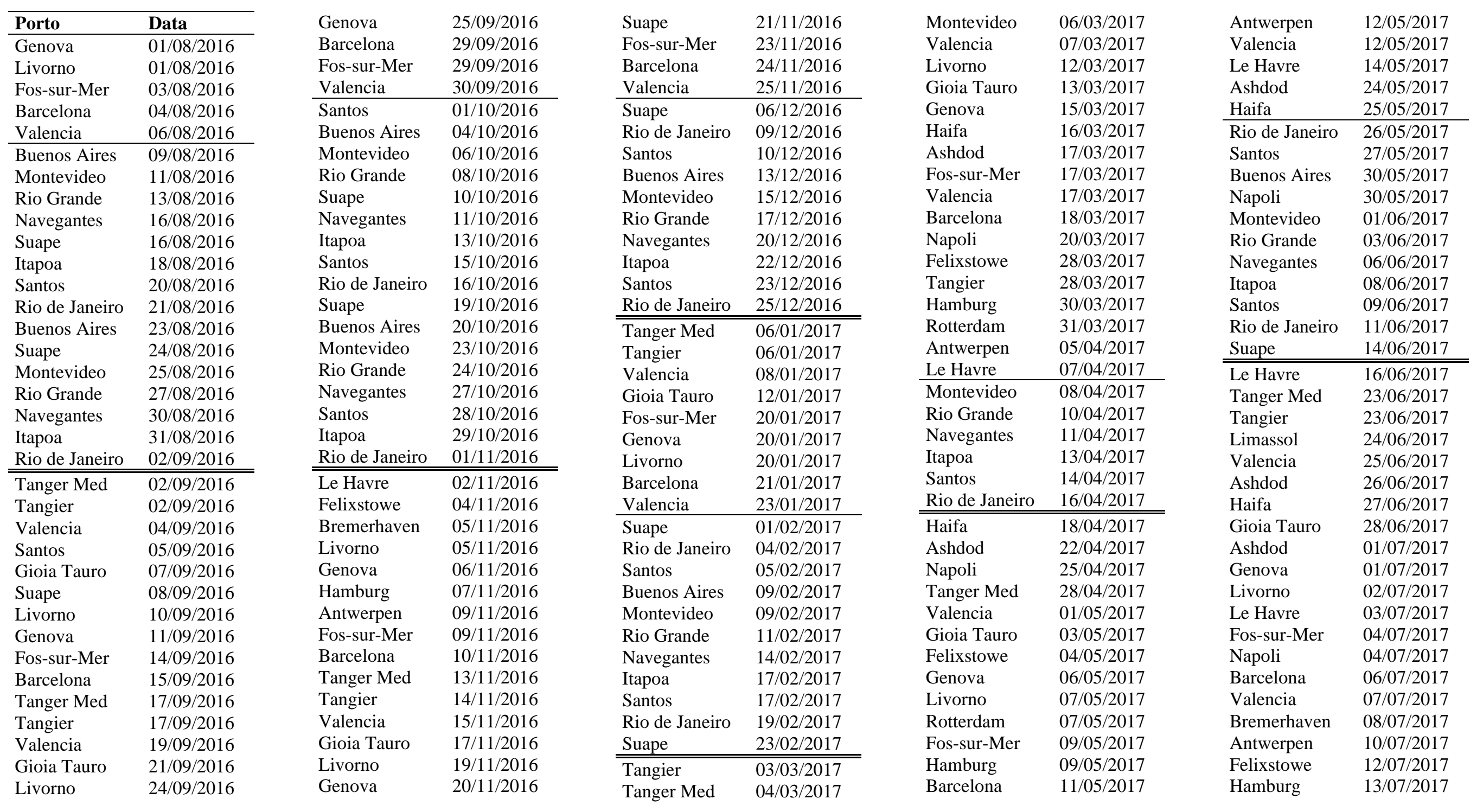


Rotterdam 13/07/2017

Antwerpen 15/07/2017

Le Havre $\quad 18 / 07 / 2017$

Rio de Janeiro 21/07/2017

Santos

$22 / 07 / 2017$

$25 / 07 / 2017$

Montevideo 27/07/2017

Limassol

29/07/2017
Rio Grande

$29 / 07 / 2017$

Fonte: autoria própria 
Tabela 57 - Parte da rota do navio Pantanal, navio da rota E, durante os anos de 2016 e 2017

\begin{tabular}{|c|c|c|c|c|c|c|c|c|c|}
\hline Porto & Data & Santos & $14 / 09 / 2016$ & Rio de Janeiro & $27 / 10 / 2016$ & Vitoria & $18 / 12 / 2016$ & Santos & $01 / 02 / 2017$ \\
\hline Rio de Janeiro & $06 / 08 / 2016$ & Rio de Janeiro & $17 / 09 / 2016$ & Vitoria & $30 / 10 / 2016$ & Santos & $21 / 12 / 2016$ & Rio de Janeiro & $04 / 02 / 2017$ \\
\hline Vitoria & $07 / 08 / 2016$ & Vitoria & $19 / 09 / 2016$ & Santos & $02 / 11 / 2016$ & Rio de Janeiro & $24 / 12 / 2016$ & Vitoria & $05 / 02 / 2017$ \\
\hline Santos & $10 / 08 / 2016$ & Santos & $23 / 09 / 2016$ & Rio de Janeiro & $05 / 11 / 2016$ & Vitoria & $25 / 12 / 2016$ & Santos & 08/02/2017 \\
\hline Rio de Janeiro & $13 / 08 / 2016$ & Rio de Janeiro & $25 / 09 / 2016$ & Vitoria & $06 / 11 / 2016$ & Santos & $28 / 12 / 2016$ & Rio de Janeiro & $11 / 02 / 2017$ \\
\hline Vitoria & $14 / 08 / 2016$ & Vitoria & 27/09/2016 & Santos & $09 / 11 / 2016$ & Rio de Janeiro & $31 / 12 / 2016$ & Vitoria & $12 / 02 / 2017$ \\
\hline Santos & $17 / 08 / 2016$ & Santos & $30 / 09 / 2016$ & Rio de Janeiro & $12 / 11 / 2016$ & Vitoria & $01 / 01 / 2017$ & Santos & $15 / 02 / 2017$ \\
\hline Rio de Janeiro & $21 / 08 / 2016$ & Vitoria & 03/10/2016 & Vitoria & $13 / 11 / 2016$ & Santos & 04/01/2017 & Rio de Janeiro & $18 / 02 / 2017$ \\
\hline Vitoria & $22 / 08 / 2016$ & Rio de Janeiro & 05/10/2016 & Santos & $16 / 11 / 2016$ & Rio de Janeiro & 07/01/2017 & Vitoria & $19 / 02 / 2017$ \\
\hline Rio de Janeiro & $27 / 08 / 2016$ & Rio de Janeiro & 08/10/2016 & Vitoria & $20 / 11 / 2016$ & Santos & $11 / 01 / 2017$ & Rio de Janeiro & $25 / 02 / 2017$ \\
\hline Vitoria & $28 / 08 / 2016$ & Vitoria & 09/10/2016 & Santos & $24 / 11 / 2016$ & Rio de Janeiro & $14 / 01 / 2017$ & Vitoria & $26 / 02 / 2017$ \\
\hline Santos & $31 / 08 / 2016$ & Santos & $12 / 10 / 2016$ & Rio de Janeiro & $28 / 11 / 2016$ & Vitoria & $15 / 01 / 2017$ & Santos & $01 / 03 / 2017$ \\
\hline Rio de Janeiro & $04 / 09 / 2016$ & Rio de Janeiro & $15 / 10 / 2016$ & Vitoria & $30 / 11 / 2016$ & Santos & $18 / 01 / 2017$ & Rio de Janeiro & $04 / 03 / 2017$ \\
\hline Vitoria & 05/09/2016 & Vitoria & $16 / 10 / 2016$ & Santos & $04 / 12 / 2016$ & Rio de Janeiro & $21 / 01 / 2017$ & Vitoria & 05/03/2017 \\
\hline Santos & 08/09/2016 & Santos & $19 / 10 / 2016$ & Rio de Janeiro & $09 / 12 / 2016$ & Vitoria & $22 / 01 / 2017$ & Santos & 08/03/2017 \\
\hline Rio de Janeiro & $11 / 09 / 2016$ & Rio de Janeiro & $20 / 10 / 2016$ & Vitoria & $11 / 12 / 2016$ & Santos & $25 / 01 / 2017$ & & \\
\hline \multirow[t]{2}{*}{ Vitoria } & $12 / 09 / 2016$ & Vitoria & $23 / 10 / 2016$ & Santos & $14 / 12 / 2016$ & Rio de Janeiro & 28/01/2017 & & \\
\hline & & Santos & $26 / 10 / 2016$ & Rio de Janeiro & $17 / 12 / 2016$ & Vitoria & $29 / 01 / 2017$ & & \\
\hline
\end{tabular}


Tabela 58 - Parte da rota do CMA CGM Marseille, navio da rota F, durante os anos de 2016 e 2017

\begin{tabular}{|c|c|c|c|c|c|c|c|c|c|}
\hline Porto & Data & Algeciras & $18 / 10 / 2016$ & Natal & $31 / 12 / 2016$ & Fortaleza & $23 / 03 / 2017$ & Degrad & 07/06/2017 \\
\hline Le Havre & $02 / 08 / 2016$ & Tilbury & $22 / 10 / 2016$ & Algeciras & $10 / 01 / 2017$ & Natal & $25 / 03 / 2017$ & Vila do Conde & $12 / 06 / 2017$ \\
\hline Philipsburg & $11 / 08 / 2016$ & Rotterdam & $23 / 10 / 2016$ & Tilbury & $14 / 01 / 2017$ & Algeciras & $04 / 04 / 2017$ & Fortaleza & $15 / 06 / 2017$ \\
\hline Port-of-Spain & $13 / 08 / 2016$ & Le Havre & $25 / 10 / 2016$ & Rotterdam & $15 / 01 / 2017$ & Tilbury & 08/04/2017 & Natal & $17 / 06 / 2017$ \\
\hline Degrad & $17 / 08 / 2016$ & Philipsburg & $03 / 11 / 2016$ & Le Havre & $17 / 01 / 2017$ & Rotterdam & 09/04/2017 & Algeciras & $27 / 06 / 2017$ \\
\hline Vila do Conde & $22 / 08 / 2016$ & Port-of-Spain & $05 / 11 / 2016$ & Philipsburg & $26 / 01 / 2017$ & Le Havre & $11 / 04 / 2017$ & Tilbury & $01 / 07 / 2017$ \\
\hline Fortaleza & $25 / 08 / 2016$ & Degrad & $08 / 11 / 2016$ & Port-of-Spain & $28 / 01 / 2017$ & Philipsburg & $20 / 04 / 2017$ & Rotterdam & 02/07/2017 \\
\hline Natal & $27 / 08 / 2016$ & Vila do Conde & $15 / 11 / 2016$ & Degrad & $31 / 01 / 2017$ & Port-of-Spain & $22 / 04 / 2017$ & Le Havre & 04/07/2017 \\
\hline Algeciras & $06 / 09 / 2016$ & Fortaleza & $19 / 11 / 2016$ & Vila do Conde & $06 / 02 / 2017$ & Degrad & $26 / 04 / 2017$ & Philipsburg & $13 / 07 / 2017$ \\
\hline Tilbury & $10 / 09 / 2016$ & Natal & $21 / 11 / 2016$ & Fortaleza & $09 / 02 / 2017$ & Vila do Conde & $01 / 05 / 2017$ & Port-of-Spain & $15 / 07 / 2017$ \\
\hline Rotterdam & $11 / 09 / 2016$ & Algeciras & $30 / 11 / 2016$ & Natal & $11 / 02 / 2017$ & Fortaleza & $04 / 05 / 2017$ & Degrad & $18 / 07 / 2017$ \\
\hline Le Havre & $12 / 09 / 2016$ & Tilbury & $03 / 12 / 2016$ & Algeciras & $22 / 02 / 2017$ & Natal & $06 / 05 / 2017$ & Vila do Conde & $24 / 07 / 2017$ \\
\hline Philipsburg & $22 / 09 / 2016$ & Rotterdam & $04 / 12 / 2016$ & Tilbury & $25 / 02 / 2017$ & Algeciras & $16 / 05 / 2017$ & Fortaleza & $27 / 07 / 2017$ \\
\hline Port-of-Spain & $25 / 09 / 2016$ & Le Havre & $06 / 12 / 2016$ & Rotterdam & $26 / 02 / 2017$ & Leixoes & $18 / 05 / 2017$ & Natal & $29 / 07 / 2017$ \\
\hline Degrad & $28 / 09 / 2016$ & Philipsburg & $15 / 12 / 2016$ & Le Havre & $28 / 02 / 2017$ & Tilbury & $20 / 05 / 2017$ & Algeciras & 08/08/2017 \\
\hline Vila do Conde & $03 / 10 / 2016$ & Port-of-Spain & $17 / 12 / 2016$ & Philipsburg & $10 / 03 / 2017$ & Rotterdam & $21 / 05 / 2017$ & & \\
\hline Fortaleza & $07 / 10 / 2016$ & Degrad & $20 / 12 / 2016$ & Port-of-Spain & $12 / 03 / 2017$ & Le Havre & $23 / 05 / 2017$ & & \\
\hline \multirow[t]{2}{*}{ Natal } & $09 / 10 / 2016$ & Vila do Conde & $26 / 12 / 2016$ & Degrad & $15 / 03 / 2017$ & Philipsburg & $01 / 06 / 2017$ & & \\
\hline & & Fortaleza & $29 / 12 / 2016$ & Vila do Conde & $20 / 03 / 2017$ & Port-of-Spain & 03/06/2017 & & \\
\hline
\end{tabular}

\section{Fonte: autoria própria}

Vila do Conde 20/03/2017 


\section{APÊNDICE E - CÁLCULO DA OFERTA PARA OS NAVIOS SPOT E “OUTROS”}

Tabela 59 - Cálculo da oferta de contêineres dos navios spot que passaram pelo Brasil no período de tempo em estudo

\begin{tabular}{llll}
\hline Navio & TEUs & $\begin{array}{l}\text { Atracações } \\
\text { no Brasil }\end{array}$ & Oferta total \\
\hline DALI & 10.000 & 1 & 10.000 \\
\hline ELLY MAERSK & 15.500 & 1 & 15.500 \\
\hline EMMA MAERSK & 15.500 & 1 & 15.500 \\
\hline ESTELLE MAERSK & 15.550 & 1 & 15.550 \\
\hline MAERSK GENOA & 10.100 & 1 & 10.100 \\
\hline MAERSK GIBRALTAR & 10.100 & 1 & 10.100 \\
\hline MAERSK & 10.100 & 1 & 10.100 \\
GUAYAQUIL & & 1 & 9.443 \\
\hline MAERSK SARAT & 9.443 & 1 & 5.606 \\
\hline MSC CAROLINA & 5.606 & 1 & 13.798 \\
\hline MSC EMANUELA & 13.798 & 1 & 14.000 \\
\hline MSC GAIA & 14.000 & 1 & 16.652 \\
\hline MSC HAMBURG & 16.652 & 1 & 5.800 \\
\hline MSC SORAYA & 5.800 & 1 & 15.908 \\
\hline MSC VENICE & 15.908 & 1 & 6.250 \\
\hline MAERSK KOBE & 6.250 & 1 & 6.860 \\
\hline MSC GENEVA & 4.860 & 1 & 6.732 \\
\hline MSC ILONA & 6.732 & 1 & \\
\hline & & & 1 \\
\hline
\end{tabular}

\begin{tabular}{llll}
\hline MSC JUDITH & 8.034 & 1 & 8.034 \\
\hline MSC KALAMATA & 6.416 & 1 & 6.416 \\
\hline MAERSK KOLKATA & 6.246 & 1 & 6.246 \\
\hline MSC ANNA & 17.273 & 1 & 17.273 \\
\hline WIDUKIND & 3.100 & 1 & 3.100 \\
\hline MSC MARGARITA & 5.762 & 1 & 5.762 \\
\hline DURANDE & 1.740 & 1 & 1.740 \\
\hline EBBA MAERSK & 15.500 & 2 & 31.000 \\
\hline ELEONORA MAERSK & 15.550 & 2 & 31.100 \\
\hline EUGEN MAERSK & 15.550 & 2 & 31.100 \\
\hline MAERSK SALTORO & 9.962 & 2 & 19.924 \\
\hline MAERSK SHAMS & 10.000 & 2 & 20.000 \\
\hline MAERSK & 9.962 & 2 & 19.924 \\
STADELHORN & & & 33.304 \\
\hline MSC AMSTERDAM & 16.652 & 2 & 38.924 \\
\hline MSC ELOANE & 19.462 & 2 & 38.874 \\
\hline MSC ERICA & 19.437 & 2 & 33.304 \\
\hline MSC ISTANBUL & 16.652 & 2 & 38.400 \\
\hline MSC MIRJAM & 19.200 & 2 & 12.492 \\
\hline MSC KINGSTON & 6.246 & 2 & \\
\hline
\end{tabular}

\section{Fonte: Autoria Própria}


Tabela 60 - Lista de navios base do Porto de Santos

\begin{tabular}{|c|c|c|c|c|}
\hline Navio & TEUs & Ano & Atracações & Oferta total \\
\hline ALLEGORIA & 5.527 & 2006 & 14 & 38.689 \\
\hline ANTHEA Y & 1.740 & 2001 & 8 & 6.960 \\
\hline $\begin{array}{l}\text { ANTOFAGASTA } \\
\text { EXPRESS }\end{array}$ & 3.500 & 2015 & 7 & 12.250 \\
\hline $\begin{array}{l}\text { ARICA } \\
\text { EXPRESS }\end{array}$ & 2.797 & 2007 & 7 & 9.790 \\
\hline BEA SCHULTE & 4.616 & 2010 & 13 & 30.004 \\
\hline BUXHARMONY & 2.702 & 2007 & 14 & 18.914 \\
\hline CAP CORTES & 3.820 & 2013 & 15 & 28.650 \\
\hline CAP SAN JUAN & 10.600 & 2015 & 9 & 47.700 \\
\hline $\begin{array}{l}\text { CAP SAN } \\
\text { LAZARO }\end{array}$ & 10.950 & 2015 & 8 & 43.800 \\
\hline $\begin{array}{l}\text { CAP SAN } \\
\text { VINCENT }\end{array}$ & 10.600 & 2015 & 8 & 42.400 \\
\hline CCNI ANDES & 9.030 & 2015 & 5 & 22.575 \\
\hline CCNI ANGOL & 9.030 & 2015 & 6 & 27.090 \\
\hline CHACABUCO & 5.527 & 2006 & 14 & 38.689 \\
\hline $\begin{array}{l}\text { CMA CGM } \\
\text { CONGO }\end{array}$ & 9.448 & 2015 & 8 & 37.792 \\
\hline $\begin{array}{l}\text { CMA CGM } \\
\text { GANGES }\end{array}$ & 9.956 & 2015 & 9 & 44.802 \\
\hline $\begin{array}{l}\text { CMA CGM } \\
\text { MEKONG }\end{array}$ & 9.956 & 2015 & 9 & 44.802 \\
\hline CONTI DARWIN & 6.078 & 1999 & 6 & 18.234 \\
\hline $\begin{array}{l}\text { COSCO } \\
\text { SHIPPING } \\
\text { VOLGA } \\
\end{array}$ & 9.092 & 2017 & 5 & 22.730 \\
\hline CS SETUBAL & 1.122 & 1997 & 11 & 6.171 \\
\hline $\begin{array}{l}\text { CSAV } \\
\text { TOCONAO }\end{array}$ & 9.000 & 2013 & 5 & 22.500 \\
\hline E.R. BERLIN & 5.762 & 2000 & 15 & 43.215 \\
\hline E.R. CANADA & 5.762 & 2001 & 7 & 20.167 \\
\hline
\end{tabular}

\begin{tabular}{lllll}
\hline E.R. DENMARK & 5.762 & 2002 & 9 & 25.929 \\
\hline E.R. SEOUL & 5.514 & 2000 & 14 & 38.598 \\
\hline E.R. SWEDEN & 5.762 & 2002 & 7 & 20.167 \\
\hline E.R. TIANAN & 8.204 & 2005 & 5 & 20.510 \\
\hline $\begin{array}{l}\text { EXPRESS } \\
\text { BRAZIL }\end{array}$ & 3.510 & 2010 & 12 & 21.060 \\
\hline $\begin{array}{l}\text { EXPRESS } \\
\text { FRANCE }\end{array}$ & 3.510 & 2010 & 11 & 19.305 \\
\hline $\begin{array}{l}\text { GERHARD } \\
\text { SCHULTE }\end{array}$ & 3.534 & 2006 & 15 & 26.505 \\
\hline HS BERLIOZ & 3.568 & 2007 & 7 & 12.488 \\
\hline HS ROSSINI & 3.568 & 2012 & 15 & 26.760 \\
\hline JPO LEO & 3.104 & 2005 & 8 & 12.416 \\
\hline JPO SCORPIUS & 2.572 & 2007 & 13 & 16.718 \\
\hline LUTETIA & 3.104 & 2005 & 14 & 21.728 \\
\hline $\begin{array}{l}\text { MAERSK } \\
\text { LAGUNA }\end{array}$ & 7.450 & 2011 & 8 & 29.800 \\
\hline $\begin{array}{l}\text { MAERSK } \\
\text { LETICIA }\end{array}$ & 7.450 & 2011 & 9 & 33.525 \\
\hline $\begin{array}{l}\text { MAERSK } \\
\text { LIRQUEN }\end{array}$ & 7.450 & 2011 & 10 & 37.250 \\
\hline MAERSK SIRAC & 7.450 & 2015 & 6 & 22.350 \\
\hline MARCH & 5.576 & 2004 & 7 & 19.516 \\
\hline MSC ABIDJAN & 8.772 & 2013 & 8 & 35.088 \\
\hline $\begin{array}{l}\text { MOL } \\
\text { ANCHORAGE }\end{array}$ & 8.762 & 2013 & 10 & 16.830 \\
\hline $\begin{array}{l}\text { MOL } \\
\text { LONDRINA }\end{array}$ & 8.700 & 2012 & 9 & \\
\hline $\begin{array}{l}\text { MOL } \\
\text { PARAMOUNT }\end{array}$ & 6.350 & 2005 & 16 & \\
\hline $\begin{array}{l}\text { MONTE } \\
\text { TAMARO }\end{array}$ & 4.000 & 2007 & 16 & \\
\hline MSC ALESSIA & 6.732 & 2001 & 5 & \\
\hline & & & & \\
\hline
\end{tabular}




\begin{tabular}{lllll}
\hline $\begin{array}{l}\text { MSC } \\
\text { JEONGMIN }\end{array}$ & 9.400 & 2016 & 7 & 32.900 \\
\hline MSC LAURA & 6.732 & 2002 & 6 & 20.196 \\
\hline MSC LILY & 8.800 & 2015 & 9 & 39.600 \\
\hline $\begin{array}{l}\text { MSC } \\
\text { LUDOVICA }\end{array}$ & 6.732 & 2003 & 15 & 50.490 \\
\hline MSC LUISA & 6.732 & 2002 & 15 & 50.490 \\
\hline MSC MAUREEN & 6.732 & 2003 & 12 & 40.392 \\
\hline $\begin{array}{l}\text { MSC } \\
\text { MICHAELA }\end{array}$ & 6.402 & 2002 & 12 & 38.412 \\
\hline MSC NAOMI & 8.800 & 2015 & 10 & 44.000 \\
\hline $\begin{array}{l}\text { MSC SARA } \\
\text { ELENA }\end{array}$ & 8.800 & 2015 & 10 & 44.000 \\
\hline MSC VANESSA & 6.732 & 2003 & 14 & 47.124 \\
\hline MSC VITA & 8.800 & 2015 & 8 & 35.200 \\
\hline NORDAMELIA & 2.500 & 2017 & 11 & 13.750 \\
\hline $\begin{array}{l}\text { NORDIC } \\
\text { BEIJING }\end{array}$ & 3.421 & 2013 & 6 & 10.263 \\
\hline $\begin{array}{l}\text { NORDIC HONG } \\
\text { KONG }\end{array}$ & 3.421 & 2013 & 5 & 8.553 \\
\hline $\begin{array}{l}\text { NORDIC } \\
\text { MACAU }\end{array}$ & 3.421 & 2013 & 7 & 11.974 \\
\hline $\begin{array}{l}\text { NORDIC } \\
\text { STRALSUND }\end{array}$ & 3.421 & 2013 & 7 & 33.600 \\
\hline $\begin{array}{l}\text { NORTHERN } \\
\text { JUVENILE }\end{array}$ & 8.400 & 2009 & 8 & \\
\hline & & & & \\
\hline
\end{tabular}

\begin{tabular}{|c|c|c|c|c|}
\hline OCEAN BLUE & 0 & 2017 & 7 & 0 \\
\hline PANDORA & 2.702 & 2008 & 15 & 20.265 \\
\hline POLONIA & 3.091 & 2003 & 16 & 24.728 \\
\hline RR EUROPA & 2.466 & 2002 & 14 & 17.262 \\
\hline $\begin{array}{l}\text { SAN ANTONIO } \\
\text { EXPRESS }\end{array}$ & 1.841 & 2008 & 7 & 6.444 \\
\hline $\begin{array}{l}\text { SAN } \\
\text { FERNANDO }\end{array}$ & 8.714 & 2015 & 8 & 34.856 \\
\hline SAN VICENTE & 9.034 & 2014 & 5 & 22.585 \\
\hline $\begin{array}{l}\text { SAN VICENTE } \\
\text { EXPRESS }\end{array}$ & 3.500 & 2014 & 7 & 12.250 \\
\hline $\begin{array}{l}\text { SEAMAX } \\
\text { ROWAYTON }\end{array}$ & 9.443 & 2015 & 9 & 42.494 \\
\hline SKYROS & 9.000 & 2014 & 8 & 36.000 \\
\hline SWITZERLAND & 9.000 & 2016 & 7 & 31.500 \\
\hline TEMPANOS & 8.000 & 2011 & 5 & 20.000 \\
\hline TUBUL & 8.000 & 2011 & 6 & 24.000 \\
\hline VALENCE & 8.800 & 2013 & 9 & 39.600 \\
\hline VALIANT & 8.800 & 2013 & 11 & 48.400 \\
\hline VALOR & 8.800 & 2013 & 10 & 44.000 \\
\hline VALUE & 8.800 & 2013 & 11 & 48.400 \\
\hline VILANO & 2.742 & 2006 & 13 & 17.823 \\
\hline ZANTE & 2.002 & 493 & 8 & 8.008 \\
\hline
\end{tabular}

Fonte: Autoria Própria 


\section{APÊNDICE F - OFERTA CALCULADA X CONTÊINERES MOVIMENTADOS PARA OS NAVIOS DA ROTA A}

Tabela 61 - Cálculos da movimentação dos contêineres

\begin{tabular}{|c|c|c|c|c|c|}
\hline Navios & $\begin{array}{l}\text { Capacidade } \\
\text { do navio }\end{array}$ & $\begin{array}{l}\text { \# de viagens } \\
\text { segundo a base da } \\
\text { Linescape }\end{array}$ & Oferta calculada & TEUs embarcados total & TEUs descarregados \\
\hline CAP SAN ANTONIO & 9814 & 10 & 98140 & 23189 & 24627 \\
\hline CAP SAN ARTEMISSIO & 9814 & 13 & 127582 & 21440 & 28434 \\
\hline CAP SAN AUGUSTIN & 9814 & 11 & 107954 & 19378 & 29266 \\
\hline CAP SAN LORENZO & 9814 & 12 & 117768 & 20953 & 28461 \\
\hline CAP SAN MALEAS & 10500 & 10 & 105000 & 22581 & 24418 \\
\hline CAP SAN MARCO & 9814 & 9 & 88326 & 21565 & 25905 \\
\hline CAP SAN NICOLAS & 9814 & 9 & 88326 & 24042 & 29971 \\
\hline CAP SAN RAPHAEL & 9814 & 9 & 88326 & 21762 & 28999 \\
\hline CEZANNE & 9971 & 4 & 39884 & 13515 & 9459 \\
\hline MAERSK LABERINTO & 8700 & 7 & 60900 & 15632 & 13887 \\
\hline MAERSK LABREA & 8700 & 7 & 60900 & 14629 & 12861 \\
\hline MAERSK LAMANAI & 8700 & 7 & 60900 & 14286 & 13799 \\
\hline MAERSK LANCO & 8700 & 7 & 60900 & 11922 & 7485 \\
\hline MAERSK LEON & 8700 & 7 & 60900 & 14741 & 13384 \\
\hline MAERSK LIMA & 7564 & 6 & 45384 & 19271 & 20006 \\
\hline MAERSK LINS & 8700 & 5 & 43500 & 17514 & 13688 \\
\hline MAERSK LOTA & 8700 & 7 & 60900 & 14872 & 11695 \\
\hline Total & & & & 311292 & 336345 \\
\hline Ocupação & & & & $37,8 \%$ & $40,8 \%$ \\
\hline
\end{tabular}

cupação

$37,8 \%$

33634

Fonte: Autoria própria 